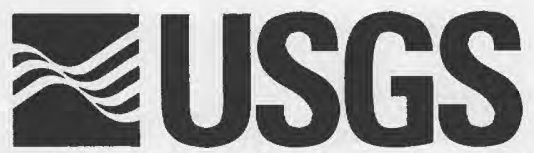

science for a changing world

NATIONAL PARK SERVICE

Water Quality and Hydrogeology near Four Wastewater-treatment Facilities in Grand Teton National Park and John D. Rockefeller, Jr., Memorial Parkway, Wyoming, September 1988 Through September 1997

Water-Resources Investigations Report 99-4117

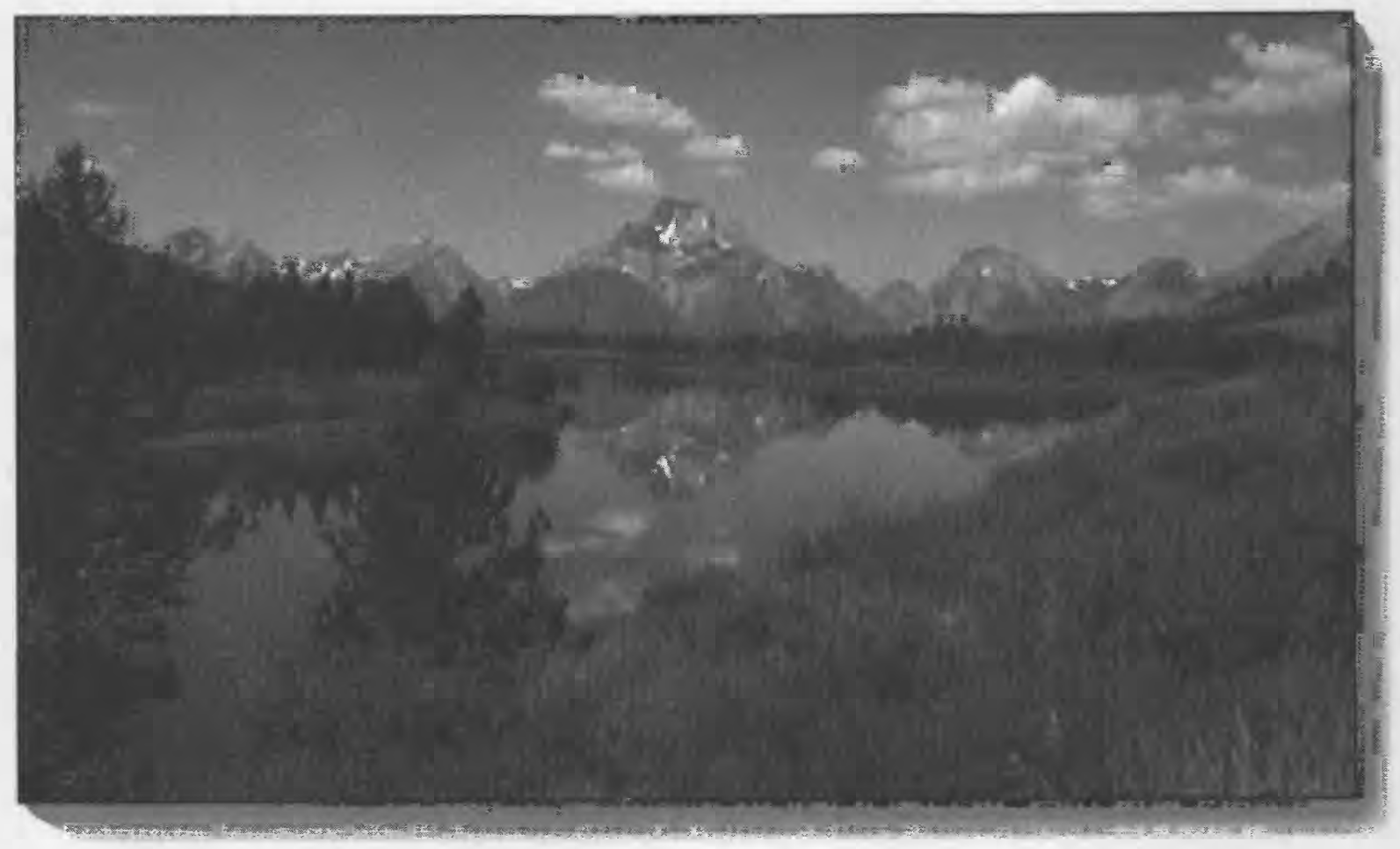

Prepared in cooperation with the

NATIONAL PARK SERVICE 


\section{Water Quality and Hydrogeology near Four Wastewater-treatment Facilities in Grand Teton National Park and John D. Rockefeller, Jr., Memorial Parkway, Wyoming, September 1988 Through September 1997}

By Kenneth J. Hedmark and H.W. Young

Water-Resources Investigations Report 99-4117

Prepared in cooperation with the

NATIONAL PARK SERVICE

Cheyenne, Wyoming

1999 


\section{U.S. Department of the Interior}

Bruce Babbitt, Secretary

\section{U.S. Geological Survey}

Charles G. Groat, Director

Any use of trade, product, or firm names in this publication is for descriptive purposes only and does not imply endorsement by the U.S. Government

For additional information write to:

\section{District Chief}

U.S. Geological Survey, WRD

2617 E. Lincolnway, Suite B

Cheyenne, Wyoming 82001-5662

Copies of this report can be purchased from:

U.S. Geological Survey

Branch of Information Services

Box 25286, Denver Federal Center

Denver, Colorado 80225 


\section{CONTENTS}

Abstract

Introduction

Purpose and scope

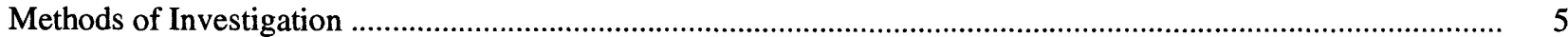

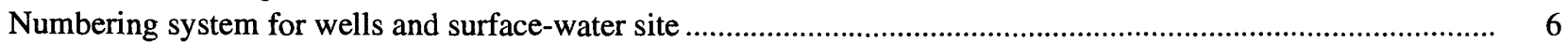

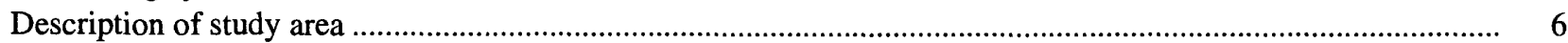

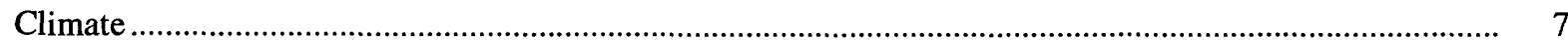

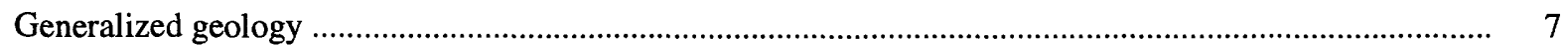

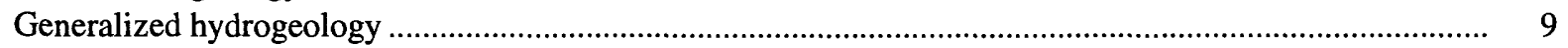

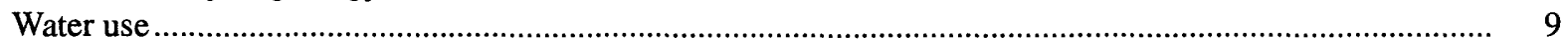

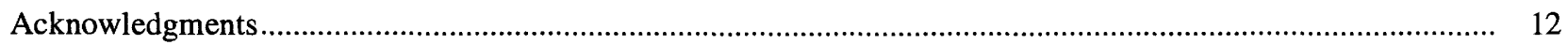

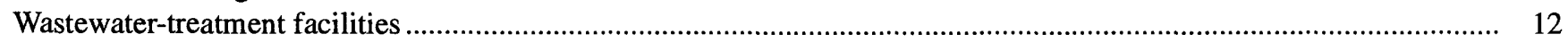

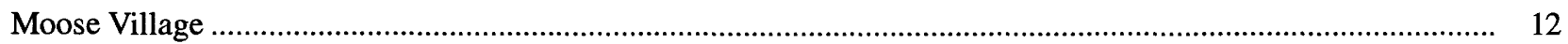

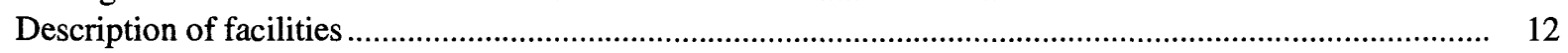

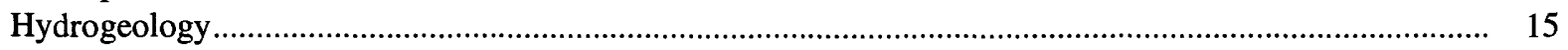

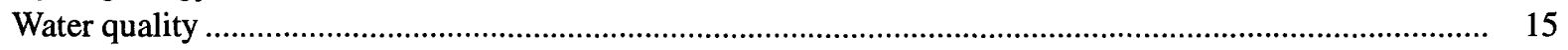

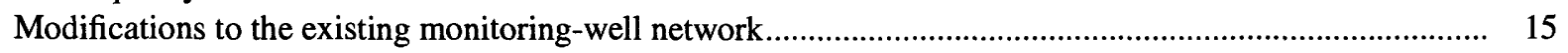

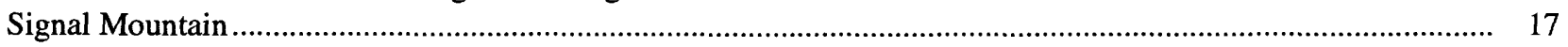

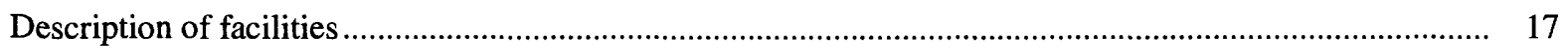

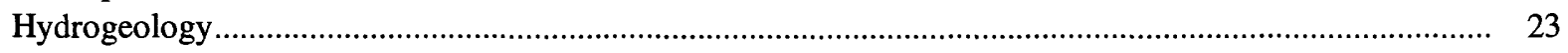

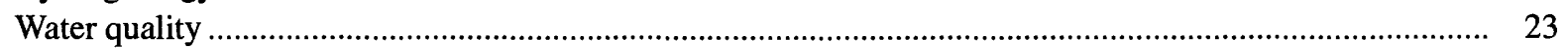

Modifications to the existing monitoring-well network ..................................................................... 29

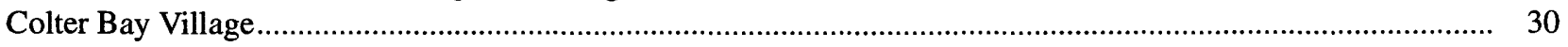

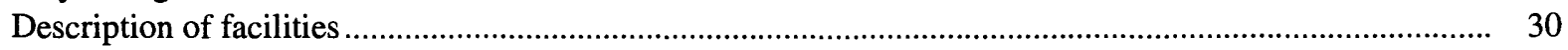

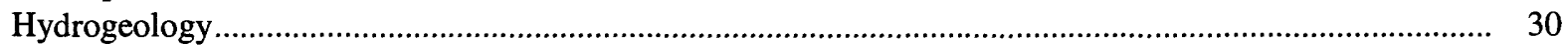

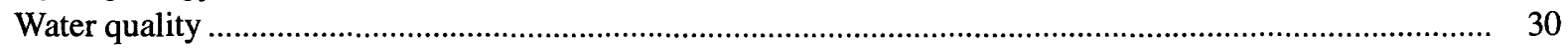

Modifications to the existing monitoring-well network .........................................................................

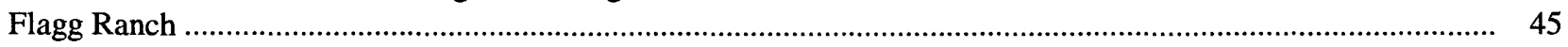

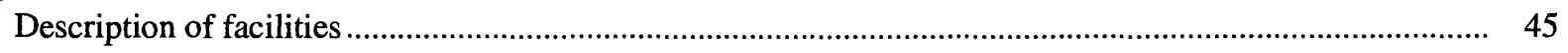

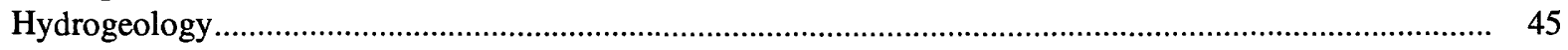

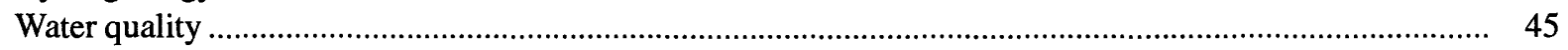

Modifications to the existing monitoring-well network ..........................................................................

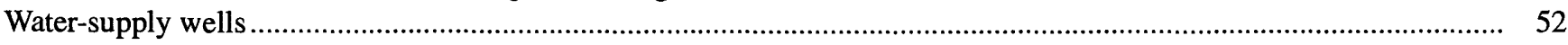

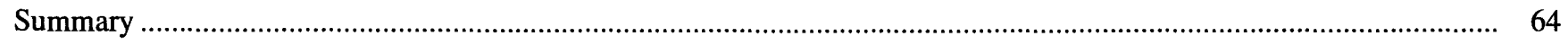

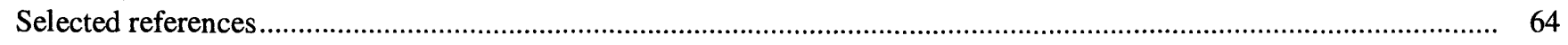

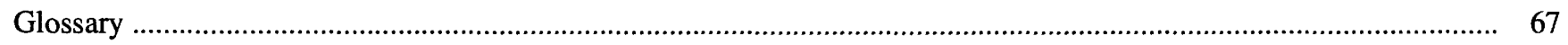

Appendix I-Available well-construction records of selected water-supply wells and monitoring wells located near four wastewater-treatment facilities in Grand Teton National Park and John D. Rockefeller, Jr.,

Memorial Parkway, Wyoming

Appendix II-Well logs of selected monitoring wells located near four wastewater-treatment facilities, in Grand Teton National Park and John D. Rockefeller, Jr., Memorial Parkway, Wyoming

\section{FIGURES}

1. Map showing location of the study area, four wastewater-treatment facilities, and selected water-supply

wells, Grand Teton National Park and John D. Rockefeller, Jr., Memorial Parkway, Wyoming ....

2. Graph showing number of visitors to Grand Teton National Park, Wyoming, 1988-97 ....................................... 4

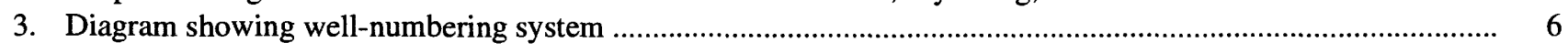


4. Graphs showing annual precipitation at three selected weather stations in Grand Teton National

Park and John D. Rockefeller, Jr., Memorial Parkway, Wyoming, 1989-97

5. Map showing location of mountain ranges near Grand Teton National Park and John D. Rockefeller, Jr., Memorial Parkway, Wyoming.

6. Map showing water-table contours for alluvium, colluvium, gravel, pediment, and fan deposits in Jackson Hole, Wyoming, July 12-21, 1993

7. Graphs showing annual water volumes produced from selected water-supply wells in relation to annual wastewater volumes processed at four wastewater-treatment facilities, 1988-97, Grand Teton

National Park and John D. Rockefeller, Jr., Memorial Parkway, Wyoming .

8. Map showing location of water-supply well and monitoring wells near Moose Village wastewatertreatment facility, and water levels measured September 23, 1997, Grand Teton National Park Wyoming ...

9. Schematic showing a generalized hydrogeologic section, depths of monitoring wells, general lithology of selected wells, and water levels measured September 23, 1997, near the Moose Village wastewatertreatment facility, Grand Teton National Park, Wyoming

10. Map showing location of water-supply wells and monitoring wells near Signal Mountain wastewatertreatment facility, and water levels measured September 23, 1997, Grand Teton

National Park, Wyoming

11. Schematic showing generalized hydrogeologic section, depths of wells, general lithology of selected wells, and water levels measured in selected wells September 23-24, 1997, near the Signal Mountain wastewater-treatment facility, Grand Teton National Park, Wyoming

12. Map showing location of monitoring wells near Colter Bay Village wastewater-treatment facility, and water levels measured September 24, 1997, Grand Teton National Park, Wyoming

13. Schematic showing generalized hydrogeologic section, depths of monitoring wells, general lithology of selected wells, and water levels measured September 24, 1997, near Colter Bay Village wastewater-treatment facility, Grand Teton National Park, Wyoming

14. Graph showing altitude of Swan Lake in comparison to water-level measurements in wells SL1 and SL2 near Swan Lake, Grand Teton National Park, Wyoming

15. Boxplots showing seasonal variability of selected constituents in samples collected from two monitoring wells located near Colter Bay Village wastewater-treatment facility, 1988-97, Grand Teton National Park, Wyoming.

16. Map showing location of water-supply wells and monitoring wells near Flagg Ranch wastewatertreatment facility, and water levels measured September 25, 1997, John D. Rockefeller, Jr., Memorial Parkway, Wyoming.

17. Schematic showing a generalized hydrogeologic section, depths of monitoring wells, general lithology of selected wells, and water levels measured September 25, 1997, near Flagg Ranch wastewatertreatment facility, John D. Rockefeller, Jr., Memorial Parkway, Wyoming

\section{TABLES}

1. Water-level measurements in monitoring wells located near Moose Village wastewatertreatment facility, Grand Teton National Park, Wyoming, September 1988 through September 1997

2. Water-quality data in samples collected from monitoring wells located near Moose Village wastewatertreatment facility, Grand Teton National Park, Wyoming, September 1988 through September 1997.

3. Water-level measurements in monitoring wells located near Signal Mountain wastewater-treatment facility, Grand Teton National Parh, Wyoming, September 1988 through September 1997

4. Water-quality data in samples collected from monitoring wells located near Signal Mountain wastewatertreatment facility, Grand Teton National Park, Wyoming, September 1988 through September 1997.

5. Water-level measurements in monitoring wells located near Colter Bay Village wastewater-treatment facility, Grand Teton National Park, Wyoming, September 1988 through September 1997 
6. Water-quality data in samples collected from monitoring wells located near Colter Bay Village wastewater-treatment facility, Grand Teton National Park, Wyoming, September 1988 through September 1997

7. Water-level measurements in monitoring wells and an unused water-supply well located near Flagg Ranch wastewater-treatment facility, John D. Rockefeller, Jr., Memorial Parkway, Wyoming, September 1988 through September 1997.

8. Water-quality data in samples collected from monitoring wells and an unused water-supply well located near Flagg Ranch wastewater-treatment facility, John D. Rockefeller, Jr., Memorial Parkway Wyoming, September 1988 through September 1997

9. Water-level measurements in selected water-supply wells in Grand Teton National Park and John D. Rockefeller, Jr., Memorial Parkway, Wyoming, September 1988 through September 1997

10. Water-quality data in samples collected from selected water-supply wells and a test well in Grand Teton National Park and John D. Rockefeller, Jr., Memorial Parkway, Wyoming, September 1988 through September 1997

11. Available well-construction records of selected water-supply wells and monitoring wells located near four wastewater-treatment facilities in Grand Teton National Park and John D. Rockefeller, Jr., Memorial Parkway, Wyoming

\section{CONVERSION FACTORS, VERTICAL DATUM, AND ABBREVIATIONS}

\begin{tabular}{rll}
\hline Multiply & By & To obtain \\
\hline inch (in.) & & \\
foot (ft) & 25.4 & millimeter (mm) \\
mile (mi) & 0.3048 & meter (m) \\
acre & 1.609 & kilometer (km) \\
gallon (gal) & 0.4047 & hectare (ha) \\
gallon (gal) & 3.785 & liter (L) \\
gallon per day (gal/d) & 0.003785 & cubic meter $\left(\mathrm{m}^{3}\right)$ \\
& 0.003785 & cubic meter per day $\left(\mathrm{m}^{3} / \mathrm{d}\right)$ \\
\hline
\end{tabular}

Temperature can be converted to degrees Fahrenheit $\left({ }^{\circ} \mathrm{F}\right)$ or degrees Celsius $\left({ }^{\circ} \mathrm{C}\right)$ as follows:

$$
\begin{aligned}
& { }^{\circ} \mathrm{F}=9 / 5\left({ }^{\circ} \mathrm{C}\right)+32 \\
& { }^{\circ} \mathrm{C}=5 / 9\left({ }^{\circ} \mathrm{F}-32\right)
\end{aligned}
$$

Sea level: In this report, "sea level" refers to the National Geodetic Vertical Datum of 1929-a geodetic datum derived from an adjustment of the first-order level nets of the United States and Canada, formerly called Sea Level Datum of 1929.

Abbreviated water-quality units used in this report:

$\mathrm{col} / 100 \mathrm{~mL} \quad$ colonies per 100 milliters of sample volume

$\mathrm{mg} / \mathrm{L} \quad$ milligrams per liter

$\mu \mathrm{S} / \mathrm{cm} \quad$ microsiemens per centimeter at 25 degrees Celsius

Abbreviations used in this report:

MRL Minimum Reporting Level

NPS National Park Service

NWQL National Water Quality Laboratory

USEPA U.S. Environmental Protection Agency

USGS U.S. Geological Survey

MCL Maximum Contaminant Level 


\title{
Nater Quality and Hydrogeology near Four Wastewater- treatment Facilities in Grand Teton National Park and John D. Rockefeller, Jr., Memorial Parkway, Wyoming, September 1988 Through September 1997
}

\author{
By Kenneth J. Hedmark and H.W. Young
}

\section{ABSTRACT}

The U.S. Geological Survey, in cooperation with the National Park Service, began data collection in 1988 to monitor the water quality at four wastewater-treatment facilities located in Grand Teton National Park and John D. Rockefeller, Jr., Memorial Parkway, Wyoming. Water-level measurements and chemical and biological waterquality samples were collected from September 1988 through September 1997 from 21 monitoring wells and 8 water-supply wells located near the facilities, and 10 water-supply wells in the study area but not directly associated with the facilities. The National Park Service requested a review of the current ground-water monitoring program in 1997 to evaluate the program's adequacy, identify any impacts that facility operations might have on ground-water quality, and suggest modifications to the existing monitoring-well network.

Water-quality data indicate that reducing conditions exist in the ground water beneath the Colter Bay Village wastewater-treatment facility. The areal and vertical extent of the zone is unknown. A seasonal variation exists for selected constituents in samples collected from monitoring well CB5, in contrast to samples collected from monitoring wells CB1, CB2, CB3, and CB4. A likely explanation for the seasonality is that treated wastewater from the facility is impacting the ground water around this well.

Contrasts in concentrations of dissolved oxygen, alkalinity, nitrate, and ammonia between monitoring well CB5 and monitoring wells CB1, CB2, CB3, and CB4 are interpreted to most likely be the result of biologically mediated oxidationreduction processes occurring in the ground water.
Reductive processes appear to be the best available explanation for the decrease in dissolvedoxygen and nitrate concentrations and the increase in ammonia concentrations in well CB5.

In general, concentrations of selected constituents were lower in the spring than in the fall. Water-quality data in samples collected at the Signal Mountain and Flagg Ranch wastewater-treatment facilities indicate that high concentrations of selected constituents correspond to periods when liners leaked in aeration ponds. Concentrations of selected constituents appeared to decrease after liner replacement at these sites, suggesting that the high concentrations were the result of the leaking liners. Low concentrations of selected constituents were analyzed in samples collected from monitoring wells located near the Moose Village wastewater-treatment facility, indicating that facility operations appear to have no apparent affect on the water quality. Water-quality samples collected from the 18 water-supply wells indicate that concentrations of selected constituents are low, also indicating that the supply wells are not being affected by wastewater-treatment facility operations.

\section{INTRODUCTION}

Grand Teton National Park and John D. Rockefeller, Jr., Memorial Parkway (fig. 1), located in northwestern Wyoming, are visited by about 4 million people per year (Linda Olson, National Park Service, written commun., 1997). Because of the large number of visitors to the Park, some of the visitor facilities produce seasonally large volumes of wastewater (Mott, 1998). The primary use period for the Park and Park 


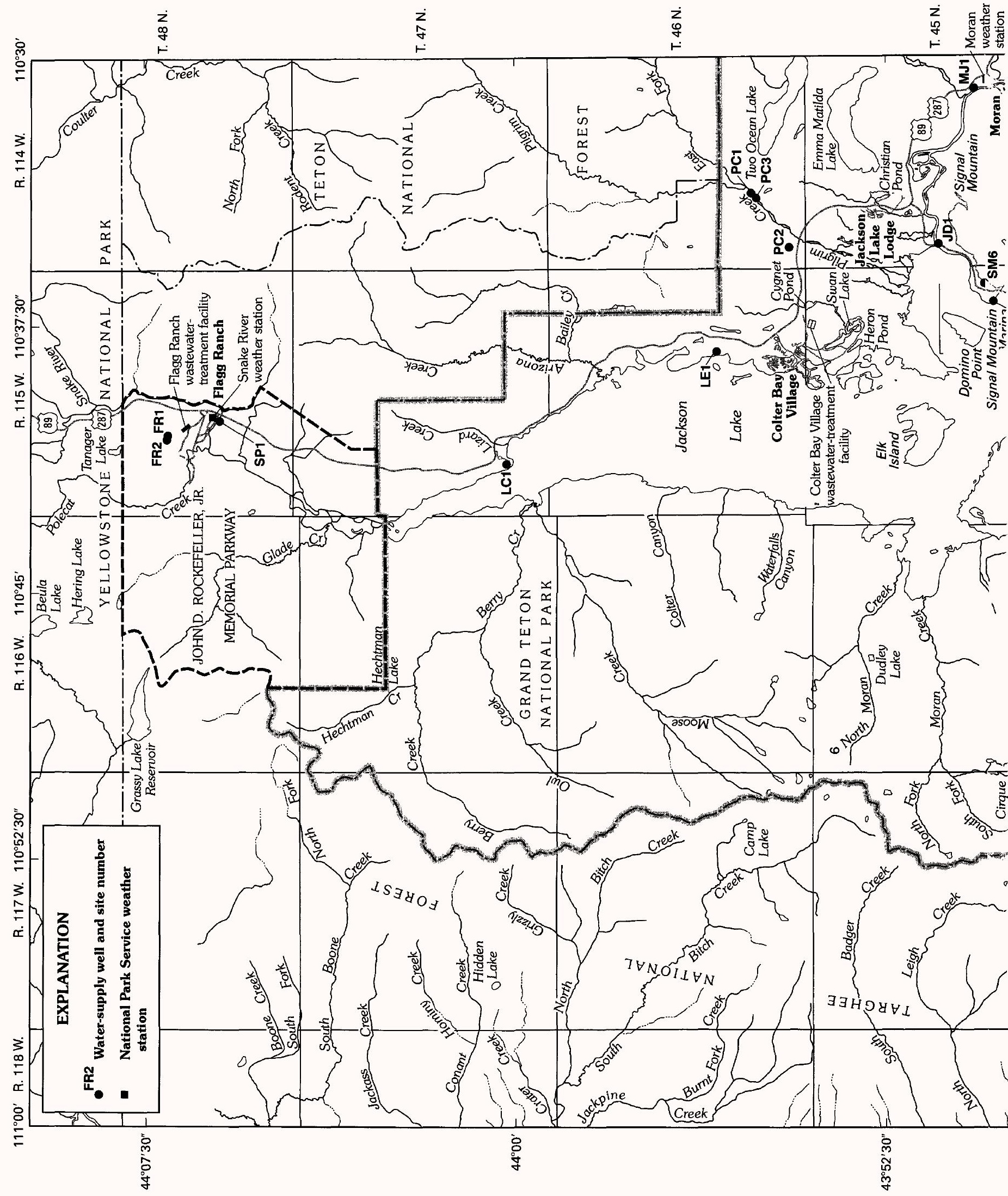




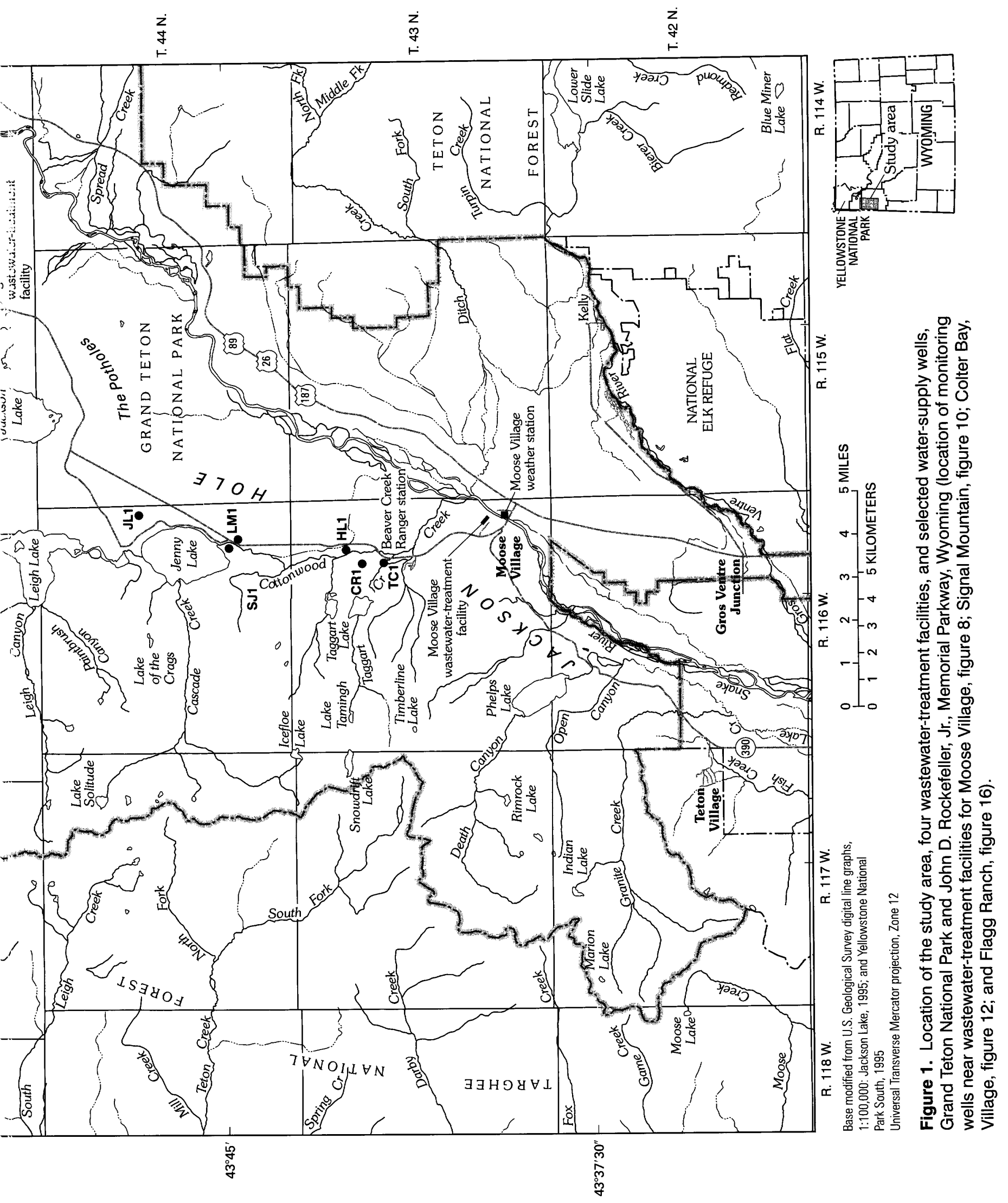


way extends from early June to mid-September, and the number of visitors to the area has increased steadily since 1988 (fig. 2). The Park and Parkway are administered jointly by the National Park Service (NPS) from park headquarters located in Moose, Wyoming (Mott, 1998).

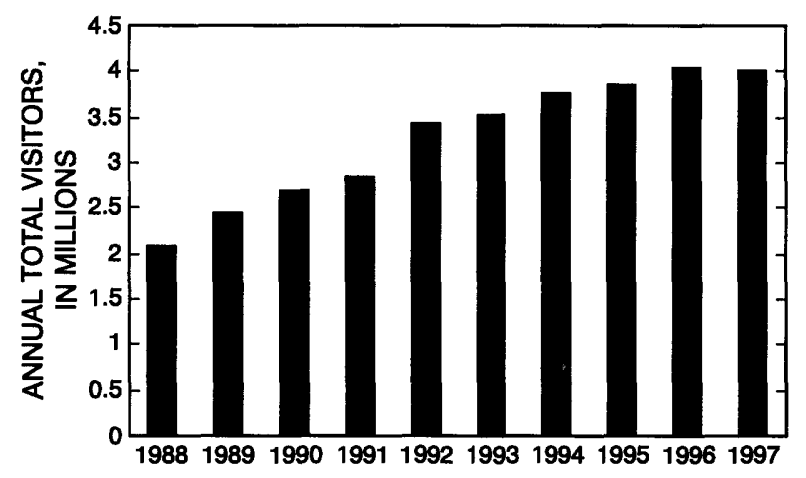

Flgure 2. Number of visitors to Grand Teton National Park, Wyoming, 1988-97 (Linda Olson, National Park Service, written commun., 1997).

Wastewater-treatment facilities located near Moose Village, Signal Mountain, Colter Bay Village, and Flagg Ranch (fig. 1) provide disposal of wastewater generated by visitors and park employees. The facilities are operated in such a manner that no sewage drains into any surface water (Mott, 1998). Large treatment facilities are located near Signal Mountain, Colter Bay, and Flagg Ranch. Aeration ponds at these facilities are used to process wastewater through aerobic digestion. The partially treated wastewater is then sent to infiltration ponds where the wastewater evaporates or percolates downward through the unsaturated zone as recharge to ground water. Wastewater generated at the Moose Village facility is discharged into an underground leach field. The leach field is of a septic tankleach field type (National Park Service, 1986). Wastewater in the leach field also percolates downward through the unsaturated zone as recharge to ground water. NPS management objectives relating to water resources include the prevention of wastewater-treatment facilities from discharging effluent directly into streams and lakes, as well as to avoid the disruption of the area's ecosystems through pollution or alteration of ground water as a result of facility operations (Mott, 1998).

A study began in 1974 by the USGS, in cooperation with the NPS, to determine the effects on nearby lakes and streams of wastewater effluents percolating from an evaporation-percolation lagoon located near Colter Bay Village in Grand Teton National Park (Cox. 1977). In 1975, the study was expanded to include the leach field located at Moose Village. Test holes were drilled at Colter Bay Village in 1975 and at Moose Village in 1976 to study the occurrence of ground water and the nature of the water-bearing materials (Cox, 1977). The test holes were completed as observation wells, and samples were collected for chemical and bacteriological analyses. Cox (1977) summarized work and data collected during 1975-76 from Moose Village and Colter Bay Village.

The USGS, in cooperation with the National Park Service, began data collection in 1988 to monitor the water quality near the four wastewater-treatment facilities. Water-level measurements and water-quality data were collected from September 1988 through Sep tember 1997. In 1997, the NPS requested a review of the current ground-water monitoring program to evaluate the programs's adequacy, identify impacts that facility operations might have on ground-water quality near the facilities, and suggest modifications to the existing monitoring-well networks.

\section{Purpose and Scope}

This report describes the effect that four wastewater-treatment facilities located near Moose Village, Signal Mountain, Colter Bay Village, and Flagg Ranch have on ground-water quality. Water-level measurements and the chemical quality of the ground water are described and evaluated based on data collected from 1988-97 from 21 monitoring wells and 18 water-supply wells. Suggestions for modifications to the existing monitoring-well networks also are included.

The general physiography, geology, and hydrogeology of the study area are described. Wastewatertreatment facility descriptions, hydrogeologic settings, and water quality near the facilities also are presented. Water-level measurements and selected biological and chemical-quality data collected in samples from monitoring wells are used to evaluate the general water quality near the facilities. The report includes a regional water-table map that was constructed as of part of another investigation of the study area, tables listing water-level measurements and water-quality data, schematics of generalized hydrogeologic sections, and water-level measurements and water-quality data in 
samples collected from selected water-supply wells located in the study area. Available well-construction records and well logs describing the general lithology at selected monitoring wells are presented in appendices. Boxplots showing the variability of selected constituents in samples collected from two wells at the Colter Bay Village wastewater-treatment facility are presented. A glossary is provided at the end of the report to assist readers with unfamiliar terms.

\section{Methods of Investigation}

Abbreviated site numbers are used in place of local numbers for all wells discussed in this report. For example, MV1 indicates well 1 at Moose Village. Site numbers, local numbers, and local names are listed in the tables.

Samples for water-quality analyses were collected during 1988-97 from 21 monitoring wells, 8 selected water-supply wells associated with wastewater-treatment facilities, and 10 selected water-supply wells not directly associated with the facilities. Samples typically were collected during late spring to early summer (May-June) and during late summer and early fall (September-October).

A peristaltic pump was used to collect samples from the shallow, small diameter monitoring wells. Selected water-supply wells were sampled by using submersible pumps in place in the wells. A minimum of three casing volumes of water was removed from each well prior to sample collection to ensure that the sample collected represented the ground water rather than water stored in the well casing. Water was pumped until specific-conductance, $\mathrm{pH}$, watertemperature, and dissolved-oxygen values stabilized.

Onsite measurements of specific conductance, $\mathrm{pH}$, water temperature, and dissolved oxygen were made immediately after the sample was collected. Total alkalinity was determined onsite. Alkalinity, as is done in this report, is commonly reported in terms of equivalent amount of calcium carbonate. Dissolvedchloride concentrations were determined onsite by using the Silver Nitrate Digital Titration method (Hach Company, 1995). Onsite screening of dissolved nitrite plus nitrate as nitrogen, was done with a spectrophotometer using the Cadmium Reduction method (Hach Company, 1995). Other nutrient samples (dissolved nitrite as nitrogen, dissolved ammonia as nitrogen, dissolved ammonia plus organic as nitrogen, and dissolved orthophosphate) collected from selected wells were submitted for analysis to the USGS National Water Quality Laboratory (NWQL) in Arvada, Colorado.

In this report, dissolved nitrite plus nitrate as nitrogen is referred to as nitrate because of the small amount of nitrite in comparison to nitrate concentration. Also, dissolved nitrite as nitrogen is referred to as nitrite and dissolved ammonia as nitrogen is referred to as dissolved ammonia. The unit for nitrite, nitrate, dissolved ammonia, and dissolved ammonia plus organic is milligrams per liter $(\mathrm{mg} / \mathrm{L})$ as nitrogen $(\mathrm{N})$. The minimum reporting level (MRL) for nitrate prior to 1991 was $0.10 \mathrm{mg} / \mathrm{L}$ as $\mathrm{N}$; since 1991 , the MRL has been $0.05 \mathrm{mg} / \mathrm{L}$ as $\mathrm{N}$. The MRL is defined as the minium concentration of an analyte that can be reliably measured and reported by the laboratory using a given analytical method. Boxplots for nitrite plus nitrate in this report are based on a reporting level of $0.10 \mathrm{mg} / \mathrm{L}$ as $\mathrm{N}$; in tables, values for cases in which the MRL was less than $0.10 \mathrm{mg} / \mathrm{L}$ as $\mathrm{N}$ were raised to $0.10 \mathrm{mg} / \mathrm{L}$ as $\mathrm{N}$ for statistical-analysis purposes.

Water-level measurements were made with a steel tape or with an electric tape from a pre-established measuring point, usually the top of the well casing. Land-surface altitudes were determined from topographic contours from USGS Quadrangle series maps (1:24,000 scale) or by level lines run from benchmarks. Selected monitoring wells were measured with a steel tape in 1988, 1990, and 1997, and depths measured are shallower in some wells than the drilling record shows, indicating that sediment has settled into the well casings since well installation. Depths measured in selected wells in 1980,1990, and 1997 are noted in table 11 in Appendix I at the end of the report. The depths measured by drop-tape are used when describing individual sites later in the report.

Samples for fecal coliform and fecal streptococci bacteria analyses were collected, processed, and placed in portable incubators onsite using methods described in Britton and Greeson (1988). Fecal coliform and fecal streptococci bacteria are present in the intestines and feces of warm-blooded animals. The concentration of bacteria in a sample of water is usually expressed as the number of bacteria colonies per 100 milliliters (col/100 mL) of water sample. Nonideal colony counts are represented as $\mathrm{K}$. Counts of less than 1 indicate that in $100 \mathrm{~mL}$ of sample volume, a count of 1 was not attained. For a more complete definition of non-ideal colony count, the reader is referred to the Glossary, on p. 67. 
Quality-assurance procedures involved calibration of all field meters and probes, and cleaning of sampling equipment prior to all site visits. Immediately prior to each sampling, meters and probes were recalibrated. Water samples were collected, preserved, shipped, and analyzed according to USGS standardized guidelines and quality-control procedures as described in Friedman and Erdmann (1982). Quality-assurance procedures used at the NWQL, described in Fishman and Friedman (1989), constituted the laboratory quality-assurance program.

\section{Numbering System for Wells and Surface- Water Site}

Wells in this study are identified by local numbers. A local number is based on the Federal townshiprange of land subdivision. An example of a local number used in this report is 44-116-26ddd01 (fig. 3). The first number (44) denotes the township ( $T$ ), the second number (116) denotes the range (R), and the third number (26) denotes the section. The first letter following the section number denotes the quarter section (160-acre tract); the second letter, the quarter-quarter section (40-acre tract); and the third letter, if shown, the quarter-quarter-quarter section (10-acre tract). These subsections are designated $a, b, c$, and $d$ in a counterclockwise direction, beginning in the northeast quadrant. The last two digits in the local number are a sequence number indicating the order of inventory. For example, well 44-116-26ddd01 is the first well inventoried in the southeast quarter of the southeast quarter of the southeast quarter of section $26, T .44$ N., R. $116 \mathrm{~W}$. All wells in the study area have ranges west of the Sixth Principle Meridian, and townships north of the 40th Parallel Base Line.

One surface-water site, near Swan Lake, is included in this report and is identified by a 15 -digit site number (435327110375602) that is based on latitude and longitude at the site. The first six digits designate latitude $\left(45^{\circ} 53^{\prime} 27^{\prime \prime}\right)$ of the site, the next seven digits designate longitude $\left(110^{\circ} 37^{\prime} 56^{\prime \prime}\right)$, and the last two digits are sequence numbers to distinguish between sites that may be in close proximity.

\section{Description of Study Area}

The study area consists of Grand Teton National Park and John D. Rockefeller, Jr., Memorial Parkway (fig. 1). The study area lies between two other popular

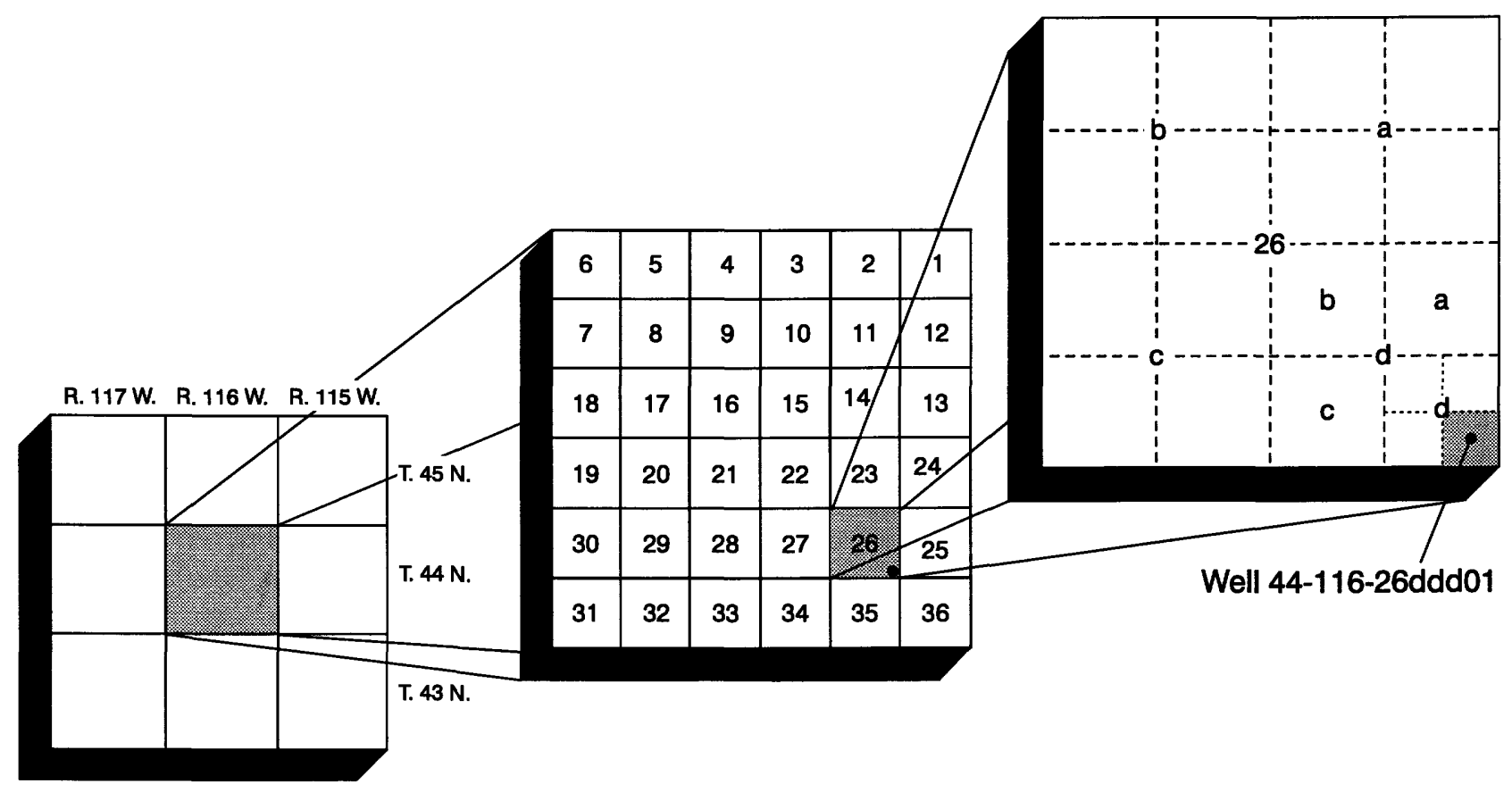

Figure 3. Well-numbering system. 


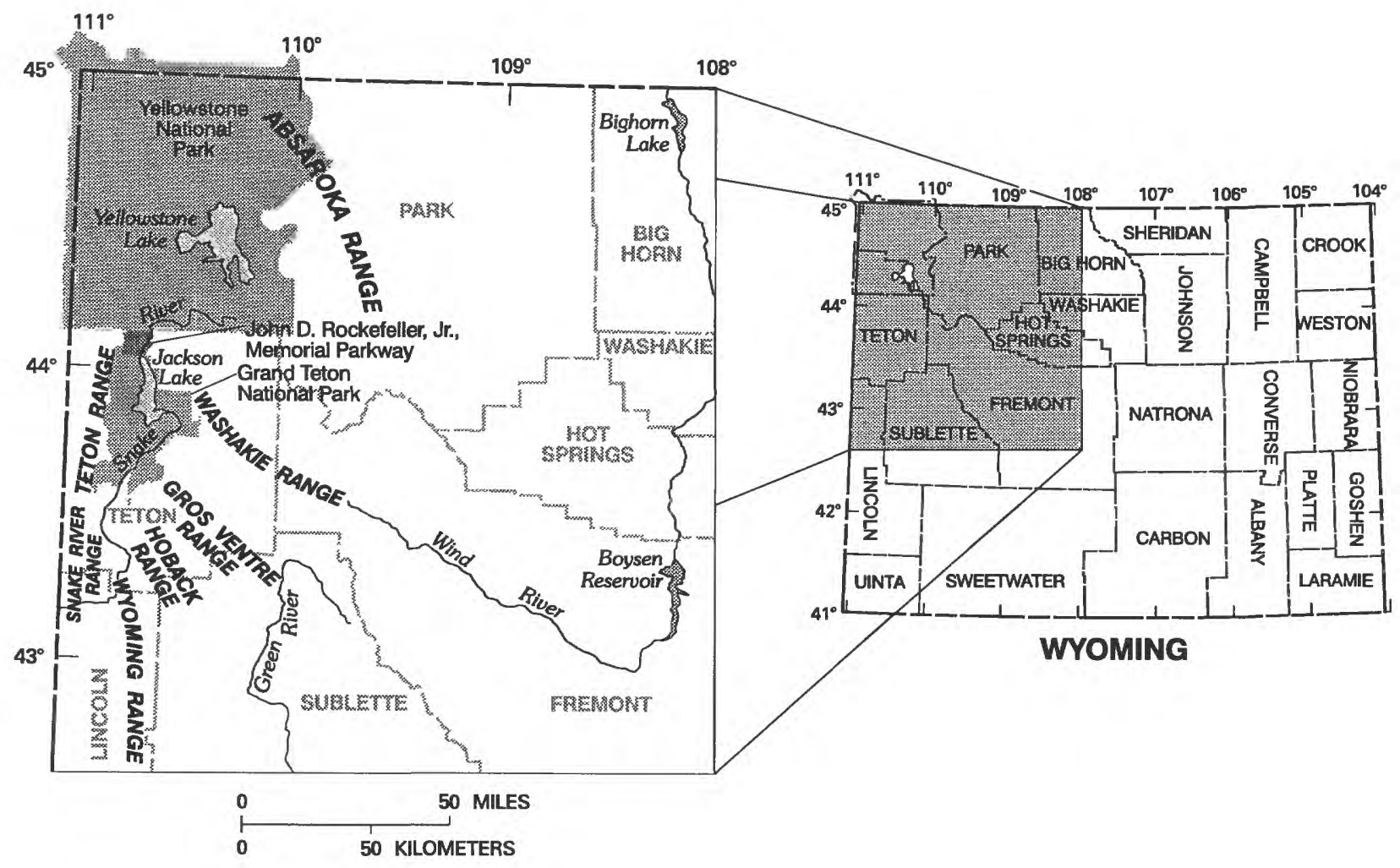

Figure 5. Location of mountain ranges near Grand Teton National Park and John D. Rockefeller, Jr., Memorial Parkway, Wyoming.

huge piles of nearly horizontal pyroclastic rocks (Tibbetts and others, 1969)). The Jackson Hole area is a structural basin that could be as much as $3.1 \mathrm{mi}$ deep (Behrendt and others, 1968) and was formed by a tilted, downthrown fault block (Love and Reed, 1968).

Glaciation has affected the Jackson Hole area at least three times, with the oldest event being the most widespread (Mott, 1998). During the last glacial advance, ice flowed down the canyons in the Teton Range and onto the floor of Jackson Hole, and built moraines that dam many of the present-day lakes in the study area, including Jackson Lake. In the study area, glacial drift occurs as discontinuous deposits around and near Jackson Lake (Love and others, 1992). Glacial deposits in the study area generally are either morainal or outwash deposits, consisting of clay, silt, sand, gravel, and cobbles and boulders, ranging in size and shape. Glacial till is dominantly unsorted and unstratified drift, generally unconsolidated, deposited directly by and underneath a glacier without subsequent reworking by meltwater (Bates and Jackson, 1980). Outwash is stratified detritus, primarily sand and gravel, transported from a glacier by meltwater streams and deposited in front or beyond the end moraine or the margin of an active glacier (Bates and Jackson, 1980). Outwash deposits are more permeable and yield water more easily to wells than do morainal deposits.

Unconsolidated deposits of Quaternary age in the study area consist of alluvium and colluvium; gravel, pediment, and fan deposits; and glacial, landslide, and undifferentiated surficial deposits (Nolan and Miller, 1995). Unconsolidated deposits typically consist of clay, silt, sand, gravel, and cobbles. Alluvium occurs as flood-plain deposits and alluvial fans in the valleys, and typically consists of well-sorted beds of silt, sand, and gravel. Much of the alluvium is glacialoutwash material that has been reworked by modern streams and greatly resembles the parent material (Mott, 1998). Colluvium refers to silt to boulder-size rocks derived from underlying and adjacent rock units and locally includes glacial drift (Love and others, 1992). Colluvium is usually deposited by rainwash, sheetwash, or slow continuous downslope creep, usually collecting at the base of gentle slopes and hillsides (Bates and Jackson, 1980). Alluvium and colluvium in 
vacation destinations, Yellowstone National Park to the north, and the resort town of Jackson, Wyoming to the south. Most of the Park and the Parkway are located in Jackson Hole, which is part of the upper Snake River valley. The study area is primarily located on a valley floor surrounded by uplands and mountains. Perennial streams draining the area are the Snake River and the Gros Ventre River and their respective tributaries.

\section{Climate}

The climate of the study area ranges from semiarid on the valley floor to humid in the higher mountains. The variation in the climatic conditions of the study area is caused primarily by topographic relief. In general, the weather is characterized by warm, dry summers that are occasionally interrupted by strong to severe thunderstorms, and cold, wet winters.

Precipitation is measured at three weather stations operated by the NPS in the study area. Annual precipitation measured near Moose Village, Moran, and Flagg Ranch during 1989-97 is shown in figure 4. For this period, annual precipitation ranged from about 15 inches (in.) near Moose Village in 1992 to about 46 in. near Moran in 1996 (National Oceanographic and Atmospheric Administration, 1989-97). The surrounding mountains may receive as much as 60 in. annually on the higher peaks (National Oceanographic and Atmospheric Administration, 1989-97). The mean monthly air temperature in the valley for the 1951-80 period of record (Martner, 1986, p. 377) ranges from about $13^{\circ} \mathrm{F}$ in January to $59.2^{\circ} \mathrm{F}$ in July, and is lower in the mountains.

\section{Generalized Geology}

The Jackson Hole area, including Grand Teton National Park and John D. Rockefeller, Jr., Memorial Parkway, is located in the northern part of the Middle Rocky Mountains Province. The physiography and geology of this area are the result of geologic processes that began during the Laramide Orogeny of Cretaceous time and continues through the present. Four types of mountains border the Jackson Hole area (fig. 5): (1) the Teton Range, a horstlike block (a horst is an elongate uplifted block bounded by faults on its long side (Bates and Jackson, 1980)); (2) the Snake River, Hoback, and Wyoming Ranges (folded and faulted sedimentary rocks underlain by thrust faults; (3) the Gros Ventre
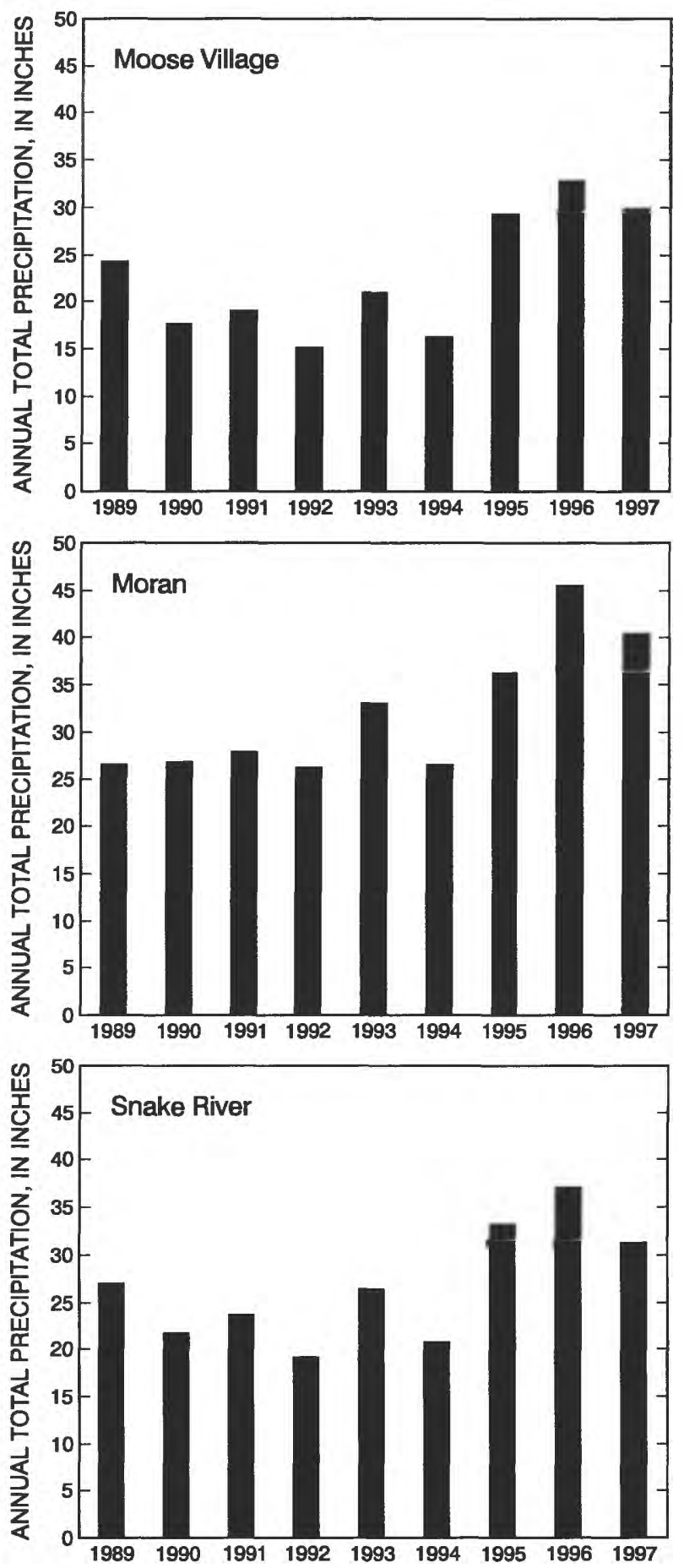

Figure 4. Annual precipitation at three selected weather stations in Grand Teton National Park and John D. Rockefeller, Jr., Memorial Parkway, Wyoming, 1989-97 (data from National Park Service).

and Washakie Ranges (folded asymmetric anticlinal uplifts with cores of Precambrian age and thrust or reverse faults along the flanks); and (4) the Absaroka Range (mountains that are the eroded remnants of 
the study area are usually found along the Snake River, Gros Ventre River, and along tributaries to these rivers. Wastewater-treatment facilities in the study area are located on alluvium and colluvium at Moose Village and Colter Bay Village, and on outwash deposits at Signal Mountain and Flagg Ranch (Love and others, 1992; Love and Christiansen, 1985).

Estimates vary about the maximum thickness of unconsolidated deposits of Quaternary age in the study area. Wells completed in these deposits in the study area generally are less than $200 \mathrm{ft}$ in depth (Nolan and Miller, 1995); thus, the maximum thickness is unknown. Nolan and Miller (1995), using a timedomain electromagnetic survey in Grand Teton National Park, estimated the thickness of unconsolidated deposits to range from about $380 \mathrm{ft}$ to about $2,400 \mathrm{ft}$ in and around the potholes area, (south of Jackson Lake, fig. 1) (Nolan and Miller, 1995, p. 39). Behrendt and others (1968) estimated that Holocene deposits (less than 10,000 years before present) range up to $400 \mathrm{ft}$ in thickness in the Jackson Hole area.

\section{Generalized Hydrogeology}

Knowledge of the lithology, stratigraphy, and structure in a region leads to an understanding of the distribution of aquifers. In unconsolidated deposits the two major controls are lithology and stratigraphy. Because this study is concerned with shallower wells completed in deposits of Quaternary age, only those deposits will be described. Some of the most important and productive aquifers in the Jackson Hole area are in Quaternary unconsolidated deposits. Aquifers in unconsolidated deposits can be recharged by infiltration of precipitation, snowmelt, lake and streamflow leakage, irrigation return flow, and by inflow from adjacent and underlying aquifers.

Ground water is discharged by pumped wells and naturally discharges by springs and seeps, by evapotranspiration, and by flow to streams and to other geologic units. Springs and seeps occur where the water table intersects land surface as a result of faults and fractures, changes in topography, or changes in lithology within a geologic unit or between geologic units (Nolan and Miller, 1995). Ground-water discharge by evapotranspiration can occur where the water table is near the land surface, such as in alluvium near streams.
Nolan and Miller (1995) developed a water-table contour map for the Jackson Hole area, including part of Grand Teton National Park (fig. 6). The map was constructed by using water-level measurements made in July 1993. Water-level contours were drawn for an area consisting of alluvium and colluvium, and gravel, pediment, and fan deposits. These deposits were combined because of their similarity, both lithologically and hydrologically. Ground water is assumed to flow in a direction perpendicular to the water-level contours, from areas of high hydraulic head to areas of low hydraulic head. The map is useful to determine the general direction of ground-water flow in part of the park for a specific time period-July 1993. The map depicts the regional ground-water flow direction; sitespecific flow directions could differ appreciably.

Ground-water-flow directions are not constant and the direction can change during different times of the year. Ground-water gradients are commonly away from rivers and streams during high flows and toward rivers and streams during low flows.

Ground water in the study area, in general, moves from topographically high areas toward the Snake River and southwest through the valley in the direction of the Snake River. Contours indicate that the Snake River was gaining in most of the valley at the time water levels were measured in July 1993 (Nolan and Miller, 1995).

Daily or weekly water-level measurements are unavailable; thus, it is difficult to map seasonal variability, although water levels in general are higher in late May and early June than in September, October, and November (tables 1, 3, 5, and 7). The higher water levels are a result of recharge in the spring by rainfall, snowmelt, and snowmelt runoff. Water levels measured in water-supply wells are not included in the discussion of individual sites because of the greater depth of the wells and the delayed response of hydraulic head at those depths.

\section{Water Use}

Water is used within the park for public water supplies at NPS facilities, for commercial and domestic use at guest ranches and private residences, and for irrigation (Mott, 1998). According to current publichealth requirements, only ground water can be used, if adequate in quantity and quality, for water supplies in areas of heavy use (Mott, 1998). 


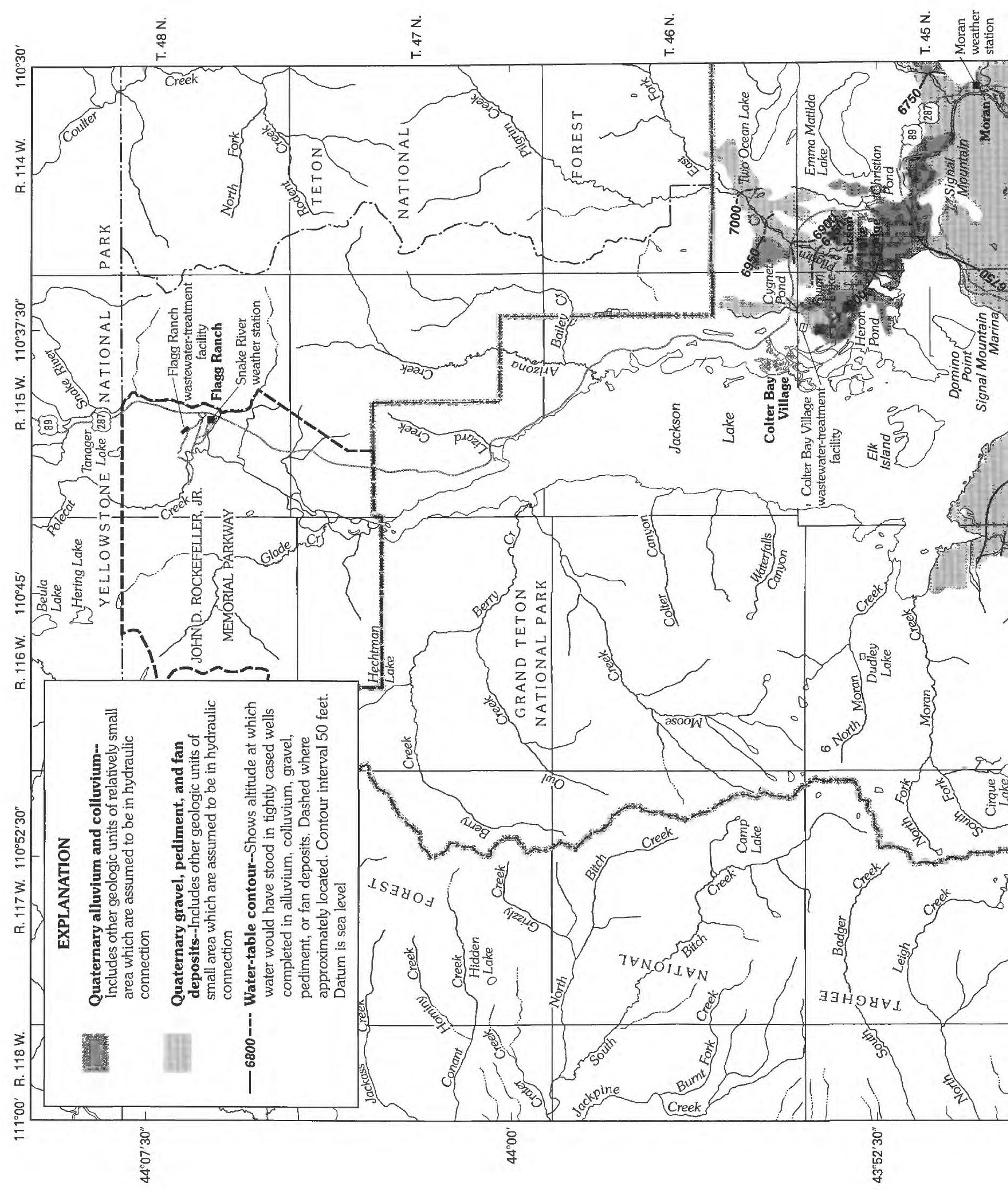




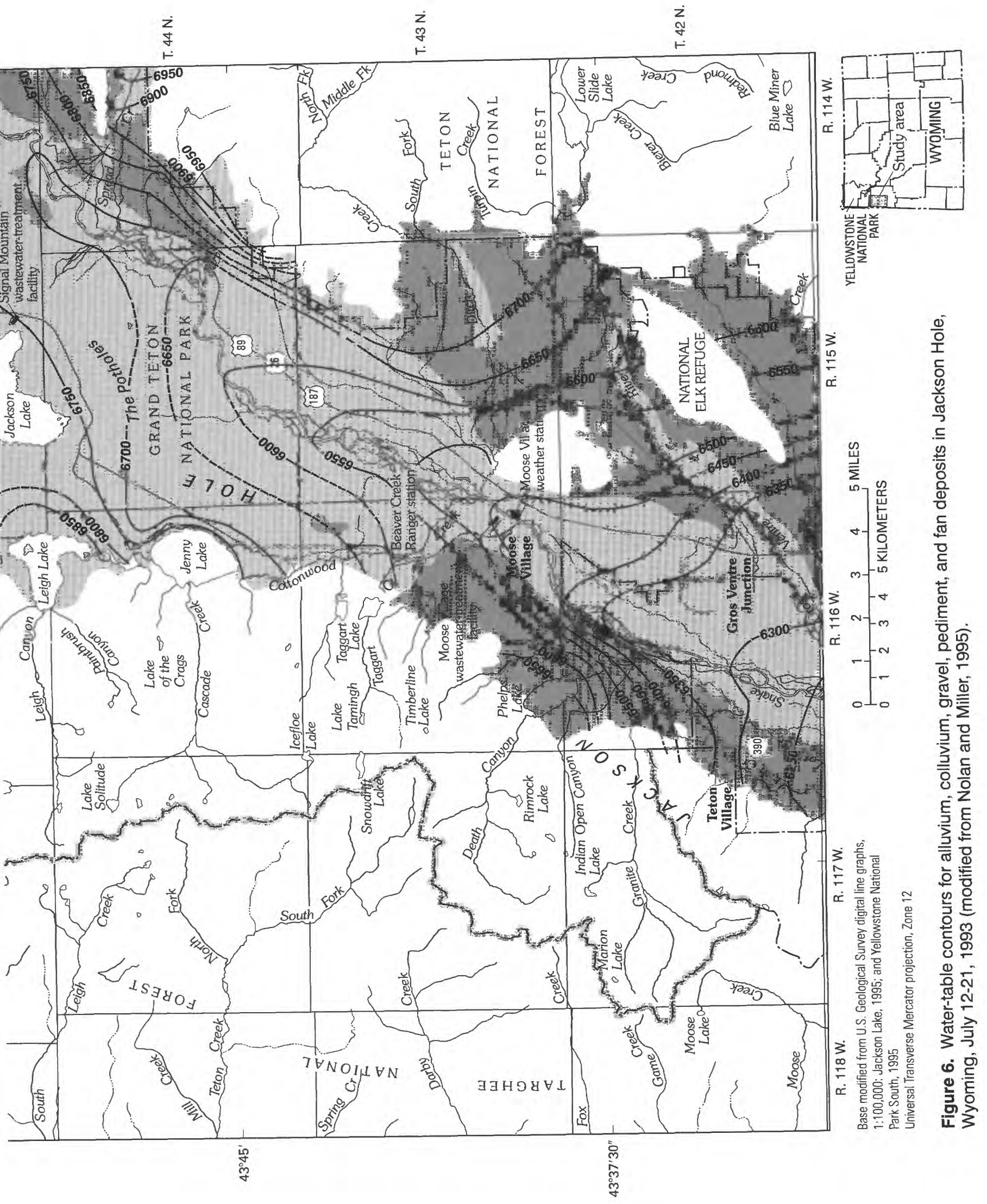


Water-supply wells provide potable water for several campgrounds, picnic areas, visitor centers, and employee housing units located throughout the park and the parkway. Selected water-supply wells located near the wastewater-treatment facilities and selected supply wells not directly associated with the facilities are shown in figure 1. Annual water volumes produced from selected water-supply wells in comparison to annual wastewater volumes processed at four wastewater-treatment facilities during 1988-97 are shown in figure 7 . The difference between water volumes produced and wastewater processed can be attributed to consumption and irrigation. No clear trends are evident in water produced in relation to wastewater processed at Moose Village, Signal Mountain, and Colter Bay Village wastewater-treatment facilities. An increasing trend is evident at Flagg Ranch, where water produced and wastewater processed have increased steadily since 1992. About an additional 8 million gallons of water was produced in 1997 in comparison to 1996. The increase in water produced and wastewater processed can be attributed to expansion of Flagg Ranch.

\section{Acknowledgments}

Appreciation is extended to the National Park Service for providing precipitation data, annual water volumes produced from the water-supply wells, annual wastewater volumes processed at the wastewatertreatment facilities, and well logs for selected wells in the study area.

\section{WASTEWATER-TREATMENT FACILITIES}

Water-level measurements and water-quality data were collected from September 1988 to September 1997. The data-collection program was designed such that water-level measurements and water-quality samples would be collected in late spring, prior to the park visitor heavy-use period, and in the fall, after the park visitor heavy-use period. However, sampling was not always consistent at each site and at every well, thus reducing direct comparability of data. Sampling was adequate to assess some impacts related to the wastewater-treatment facilities. The frequency of water-level measurements and water-quality samples do not adequately reflect seasonal water-level changes or a seasonal water-quality component. Knowledge of seasonal water-level changes is necessary to assess seasonal ground-water flow direction, flow paths within the aquifer, and the relations between facility operations and the water table. At each facility, a network of wells was installed to monitor potential contamination. Well locations are adequate at most facilities; however, wells are open only at the bottom, have narrow perforated or screened intervals, and are completed at different altitudes and in different geologic materials. Thus, comparability of data collected from the wells is limited. Although monitoring-well construction does not meet standard guidelines, data collected at most facilities provide an indication of whether a problem exists at a particular facility. Well construction, and well locations in some cases, however, limit the hydrogeologic and water-quality interpretations that can be made at the facilities.

\section{Moose Village}

\section{Description of Facilities}

Moose Village includes employee housing units, a large maintenance complex, a visitor center, and headquarters offices for Grand Teton National Park. The Moose Village wastewater-treatment facility, constructed in 1974, is located at Moose Village (fig. 8). Treated wastewater is pumped to a leach field located about $2000 \mathrm{ft}$ north of Moose Village. The leach-field system is designed to process as much as 37,600 gallons per day.

Vegetation in the vicinity of the leach field is predominately sage brush, grasses, and sparse cottonwood trees. Vegetation might use some of the wastewater through evapotranspiration, but most of wastewater percolates downward through the soil and the unsaturated zone (about the upper $10 \mathrm{ft}$ ) as recharge to ground water.

Three wells (MV1, MV2, and MV3), ranging in depth from 43 to $49 \mathrm{ft}$, were installed near the leach field to measure water levels and to monitor groundwater quality (fig. 8). The wells are perforated at various 1 foot intervals. Construction records for the three monitoring wells are listed in table 11 in Appendix I at the end of the report. 


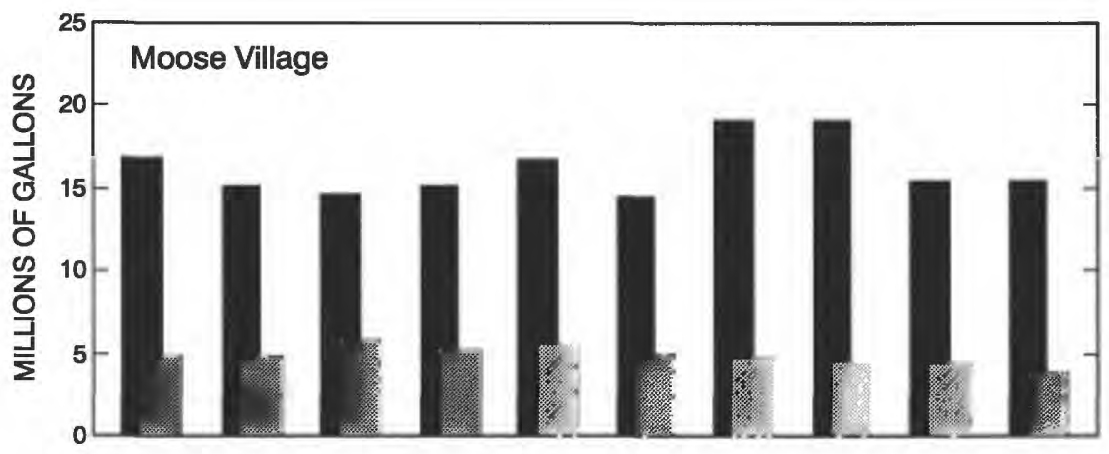

\author{
EXPLANATION \\ POTABLE WATER FROM \\ TAGGART CREEK WATER- \\ SUPPLY WELL TC1 (fig. 8) \\ WASTEWATER PROCESSED AT \\ MOOSE VILLAGE WASTE- \\ WATER TREATMENT FACILITY
}

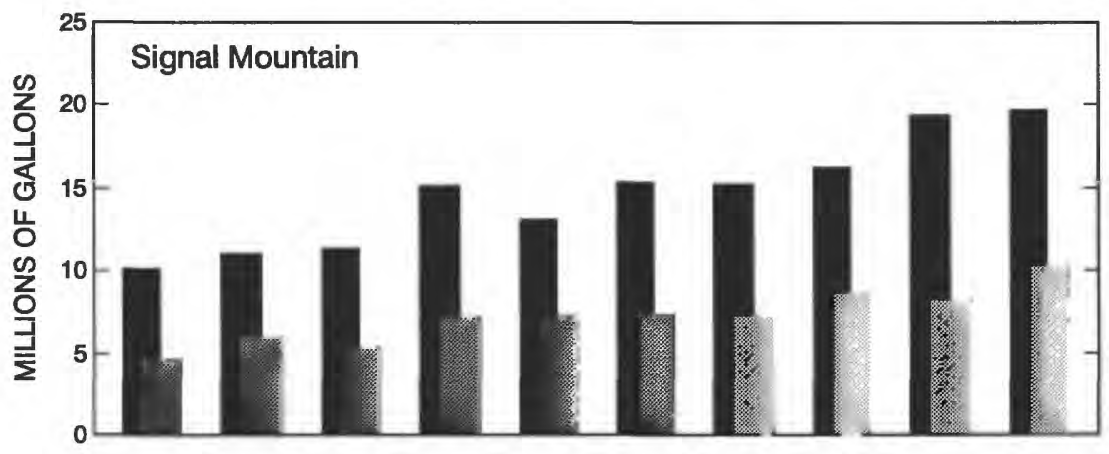

\title{
EXPLANATION
}

POTABLE WATER FROM SIGNAL MOUNTAIN WATER-SUPPLY WELL SM6 (fig. 10)

WASTEWATER PROCESSED AT SIGNAL MOUNTAIN WASTEWATER TREATMENT FACILITY

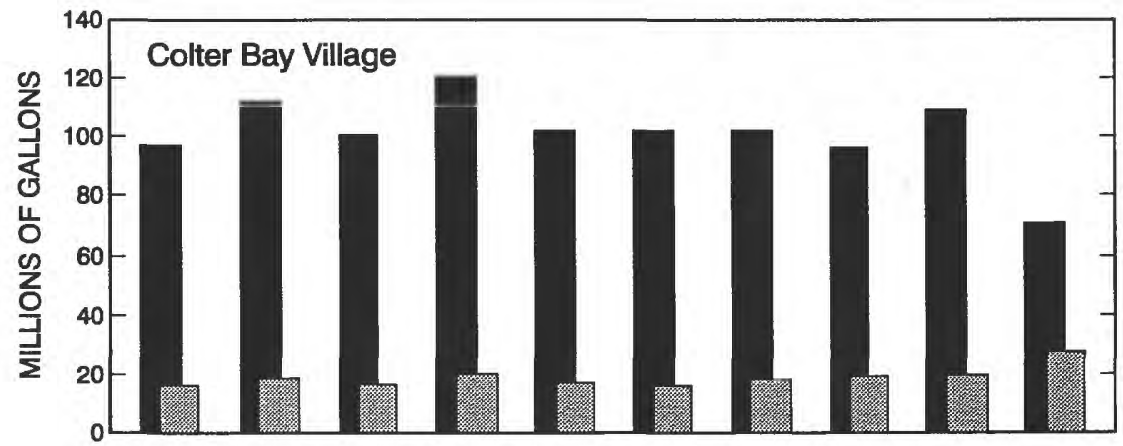

\section{EXPLANATION}

POTABLE WATER FROM PILGRIM CREEK WATERSUPPLY WELLS PC1, PC2, and PC3 (fig. 1)

WASTEWATER PROCESSED AT COLTER BAY VILLAGE WASTEWATER TREATMENT FACILITY

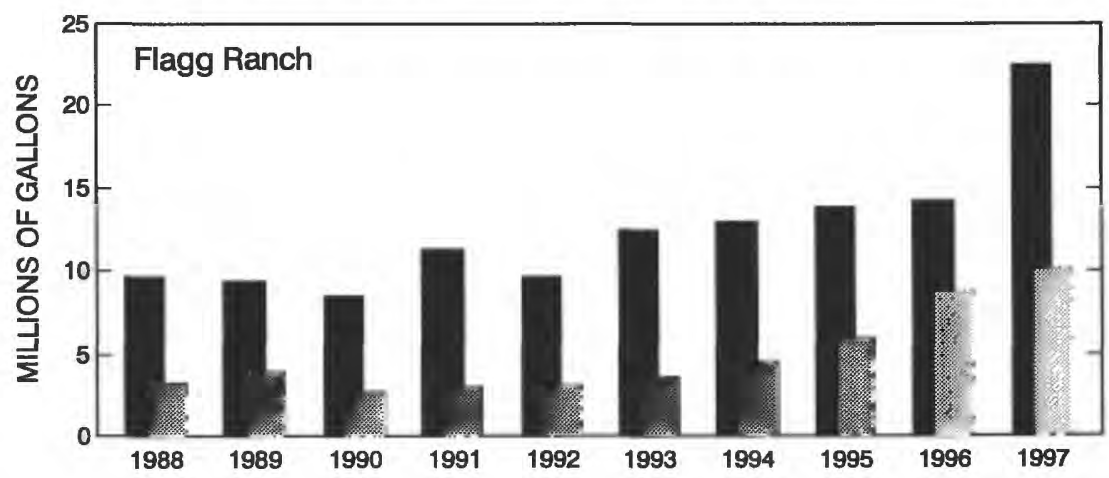

\section{EXPLANATION}

POTABLE WATER FROM FLAGG RANCH WATERSUPPLY WELLS FR1 AND FR2 (fig. 16)

WASTEWATER PROCESSED AT FLAGG RANCH WASTE-WATER TREATMENT FACILITY

Figure 7. Annual water volumes produced from selected water-supply wells in relation to annual wastewater volumes processed at four wastewater-treatment facilities, 1988-97, Grand Teton National Park and John D. Rockefeller, Jr., Memorial Parkway, Wyoming (Michael Zuppo, National Park Service, written commun., 1997). 


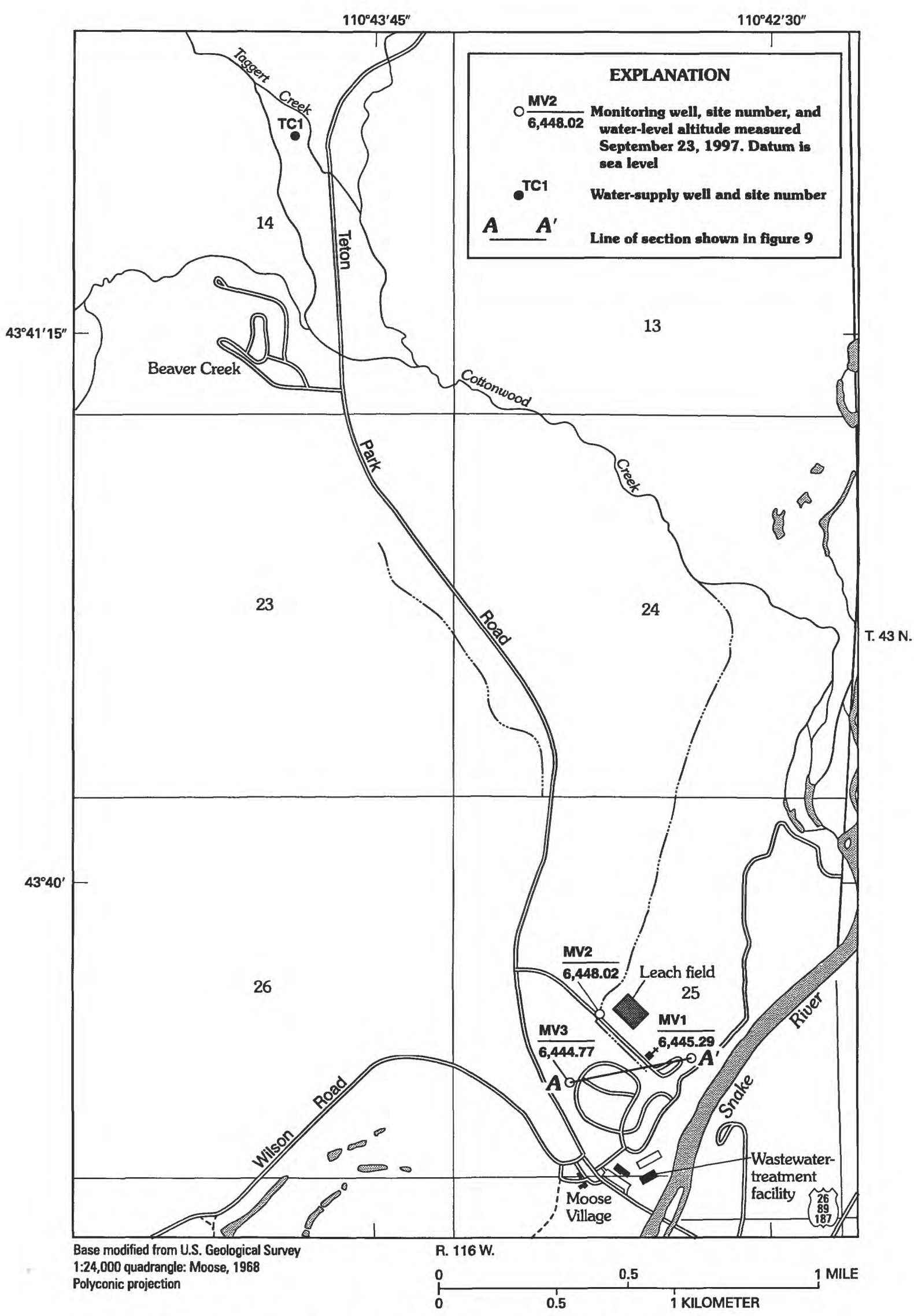

Figure 8. Location of water-supply well and monitoring wells near Moose Village wastewater-treatment facility, and water-levels measured September 23, 1997, Grand Teton National Park, Wyoming. 


\section{Hydrogeology}

Well logs indicate that the three monitoring wells are completed in unconsolidated deposits consisting of clay, silt, sand, gravel, cobbles, and boulders. Well logs of MV1, MV2, and MV3 are shown in figure B-1 in Appendix II at the end of the report. Love and others (1992) indicate the facility is constructed on alluvium, consisting primarily of sand and gravel and flood-plain deposits. Water-level measurements made in monitoring wells from September 1988 through September 1997 are listed in table 1. Water levels measured September 23, 1997 are shown in figure 8. A generalized hydrogeologic section, the depths of selected monitoring wells, the water level measured September 23, 1997, and the general lithology at monitoring wells MV1, MV2, and MV3 are shown in figure 9. Contours on the water-table map for July 1993 (fig. 6) indicate that the regional ground-water flow was to the southwest, toward the Snake River.

\section{Water Quality}

Water-quality samples were collected September 1988 through September 1997 from the three monitoring wells (MV1, MV2, and MV3). Water-quality data are summarized in this section because wastewatertreatment facility operations appear to have no apparent affect on the quality of water near the facility. Water-quality data are listed in table 2.

Specific conductance ranged from 62 to $220 \mu \mathrm{S} / \mathrm{cm}$ in samples collected from the three monitoring wells. In general, the highest values were measured in wells MV1 and MV2. Dissolved-oxygen concentrations ranged from 1.4 to $7.1 \mathrm{mg} / \mathrm{L}$ in $\mathrm{MV} 1$ and MV2 and from 5.7 to $6.4 \mathrm{mg} / \mathrm{L}$ in MV3.

Fecal coliform bacteria concentrations were less than $1 \mathrm{col} / 100 \mathrm{~mL}$ in samples collected from all three wells. Fecal streptococci concentrations ranged from less than 1 to $23 \mathrm{col} / 100 \mathrm{~mL}$. The two higher concentrations-23 col/100 mL and $\mathrm{K} 8 \mathrm{col} / 100 \mathrm{~mL}$ - occurred in September 1993. After September 1993, concentrations ranged from less than 1 to $\mathrm{K} 3 \mathrm{col} / 100 \mathrm{~mL}$. A sample collected from MV1 had a concentration of $\mathrm{K} 2 \mathrm{col} / 100 \mathrm{~mL}$ in September 1996 and samples collected from MV2 had concentrations of $\mathrm{K} 1 \mathrm{col} / 100 \mathrm{~mL}$ in July 1995 and K3 col/100 mL in September 1997. Concentrations were less than $1 \mathrm{col} / 100 \mathrm{~mL}$ after June 1994 in samples collected from MV3. In all but one case the higher concentrations were in samples collected during the fall sampling period.

Alkalinity concentrations ranged from 56 to $113 \mathrm{mg} / \mathrm{L}$ in samples collected from wells MV1 and MV2 and 35 to $51 \mathrm{mg} / \mathrm{L}$ in samples from well MV3. Dissolved-chloride concentrations, in general, ranged from less than 1 to $2 \mathrm{mg} / \mathrm{L}$ in samples from the three wells. One sample collected in July 1995 from MV3 had a concentration of $6 \mathrm{mg} / \mathrm{L}$. Samples collected from the same well in 1996-97 had chloride concentrations of $2 \mathrm{mg} / \mathrm{L}$. One sample collected from MV2 in July 1995 had a dissolved-chloride concentration of $5 \mathrm{mg} / \mathrm{L}$.

Nitrate concentrations ranged from less than 0.05 to $0.34 \mathrm{mg} / \mathrm{L}$ as $\mathrm{N}$. Nitrite concentrations were less than $1 \mathrm{mg} / \mathrm{L}$ as $\mathrm{N}$; dissolved-ammonia concentrations ranged from less than 0.01 to $0.05 \mathrm{mg} / \mathrm{L}$ as $\mathrm{N}$; dissolved-ammonia plus organic concentrations were less than $0.2 \mathrm{mg} / \mathrm{L}$ as $\mathrm{N}$, except for one sample collected in May 1990, which had a concentration of $0.8 \mathrm{mg} / \mathrm{L}$ as $\mathrm{N}$. Orthophosphate concentrations ranged from less than 0.01 to $0.05 \mathrm{mg} / \mathrm{L}$.

\section{Modifications to the Existing Monitoring-well Network}

To determine the direction of horizontal and vertical ground-water flow and to better monitor water quality at the Moose Village wastewater-treatment facility, three clusters of wells (three wells per cluster) installed near the eastern, southern, and western border of the leach field would be useful. In theory, a leach field should be above the water table at all times. Wells completed with 5- to 10 -ft screened intervals at different depths will allow any vertical component of flow to be measured and water-quality changes with depth to be assessed. The shallowest well of each cluster could be constructed so that the top of the screen would be above the water table. A cluster of wells installed north of the leach field could help provide samples to determine background concentrations of selected constituents and help determine if concentrations observed in samples collected from wells at the site are a result of facility operations. Ground-water flow direction in the Moose Village area would be better defined by collecting water-level measurements in the newly installed well. Wells MV1, MV2, and MV3 would be available for additional sampling if necessary. 
Table 1. Water-level measurements in monitoring wells located near Moose Village wastewater-treatment facility, Grand Teton National Park, Wyoming, September 1988 through September 1997

[Local number: See text describing well-numbering system. *, altitude of land surface estimated from topographic contours from U.S. Geological Survey Quadrangle series maps (1:24,000 scale); otherwise, no asterisk denotes altitude of land surface determined by level line run from benchmarks]

\begin{tabular}{|c|c|c|c|c|c|c|c|}
\hline $\begin{array}{c}\text { Site } \\
\text { number } \\
\text { (fig. 8) }\end{array}$ & Local number & Local name & $\begin{array}{c}\text { Altitude of } \\
\text { land surface } \\
\text { (feet above } \\
\text { sea level) }\end{array}$ & $\begin{array}{l}\text { Depth of well } \\
\text { (feet below } \\
\text { land surface) }\end{array}$ & $\begin{array}{c}\text { Water level } \\
\text { date }\end{array}$ & $\begin{array}{l}\text { Water level } \\
\text { (feet below } \\
\text { land surface) }\end{array}$ & $\begin{array}{c}\text { Water level } \\
\text { (feet above } \\
\text { sea level) }\end{array}$ \\
\hline \multirow[t]{19}{*}{ MV1 } & $43-116-25 \mathrm{dbd} 01$ & Moose Village 1 & $6,460 *$ & 49 & $09-08-88$ & 15.39 & 6444.61 \\
\hline & & & & & $05-31-89$ & 14.14 & 6445.86 \\
\hline & & & & & 09-06-89 & 14.13 & 6445.87 \\
\hline & & & & & $05-31-90$ & 15.98 & 6444.02 \\
\hline & & & & & $09-04-90$ & 14.28 & 6445.72 \\
\hline & & & & & $06-04-91$ & 12.12 & 6447.88 \\
\hline & & & & & 09-04-91 & 14.69 & 6445.31 \\
\hline & & & & & $06-03-92$ & 12.94 & 6447.06 \\
\hline & & & & & $09-10-92$ & 14.70 & 6445.30 \\
\hline & & & & & $06-02-93$ & 12.89 & 6447.11 \\
\hline & & & & & $07-14-93$ & 13.12 & 6446.88 \\
\hline & & & & & $09-08-93$ & 14.19 & 6445.81 \\
\hline & & & & & $06-01-94$ & 12.69 & 6447.31 \\
\hline & & & & & $09-07-94$ & 14.49 & 6445.51 \\
\hline & & & & & $10-26-94$ & 16.58 & 6443.42 \\
\hline & & & & & $06-02-95$ & 12.37 & 6447.63 \\
\hline & & & & & $07-25-95$ & 13.26 & 6446.74 \\
\hline & & & & & $09-17-96$ & 14.83 & 6445.17 \\
\hline & & & & & $09-23-97$ & 14.71 & 6445.29 \\
\hline \multirow[t]{19}{*}{ MV2 } & 43-116-25caa01 & Moose Village 2 & $6,462 *$ & 43 & $09-08-88$ & 14.84 & 6447.16 \\
\hline & & & & & $05-31-89$ & 13.40 & 6448.60 \\
\hline & & & & & 09-06-89 & 13.62 & 6448.38 \\
\hline & & & & & $05-31-90$ & 14.47 & 6447.53 \\
\hline & & & & & $09-04-90$ & 12.79 & 6449.21 \\
\hline & & & & & $06-04-91$ & 12.51 & 6449.49 \\
\hline & & & & & 09-04-91 & 13.98 & 6448.02 \\
\hline & & & & & $06-03-92$ & 12.71 & 6449.21 \\
\hline & & & & & $09-10-92$ & 14.18 & 6447.82 \\
\hline & & & & & $06-02-93$ & 12.34 & 6449.66 \\
\hline & & & & & $07-12-93$ & 13.18 & 6448.82 \\
\hline & & & & & $09-08-93$ & 13.62 & 6448.38 \\
\hline & & & & & $06-01-94$ & 12.81 & 6449.19 \\
\hline & & & & & $09-07-94$ & 13.95 & 6448.05 \\
\hline & & & & & $10-26-94$ & 15.90 & 6446.10 \\
\hline & & & & & $06-02-95$ & 12.47 & 6449.53 \\
\hline & & & & & $07-25-95$ & 12.69 & 6449.31 \\
\hline & & & & & $09-17-96$ & 14.75 & 6447.25 \\
\hline & & & & & $09-23-97$ & 13.98 & 6448.02 \\
\hline \multirow[t]{5}{*}{ MV3 } & $43-116-25 \mathrm{cca} 01$ & Moose Village 3 & $6,455.10$ & 49 & $05-31-89$ & 9.87 & 6445.23 \\
\hline & & & & & $09-06-89$ & 10.19 & 6444.91 \\
\hline & & & & & $05-31-90$ & 10.17 & 6444.93 \\
\hline & & & & & $09-04-90$ & 10.34 & 6444.76 \\
\hline & & & & & $06-04-91$ & 9.19 & 6445.91 \\
\hline
\end{tabular}


Table 1. Water-level measurements in monitoring wells located near Moose Village wastewater-treatment facility, Grand Teton National Park, Wyoming, September 1988 through September 1997--Continued

\begin{tabular}{|c|c|c|c|c|c|c|c|}
\hline $\begin{array}{c}\text { Site } \\
\text { number } \\
\text { (fig. 8) }\end{array}$ & Local number & Local name & $\begin{array}{c}\text { Altitude of } \\
\text { land surface } \\
\text { (feet above } \\
\text { sea level) }\end{array}$ & $\begin{array}{l}\text { Depth of well } \\
\text { (feet below } \\
\text { land surface) }\end{array}$ & $\begin{array}{c}\text { Water level } \\
\text { date }\end{array}$ & $\begin{array}{l}\text { Water level } \\
\text { (feet below } \\
\text { land surface) }\end{array}$ & $\begin{array}{c}\text { Water level } \\
\text { (feet above } \\
\text { sea level) }\end{array}$ \\
\hline MV3-- & & & & & 09-04-91 & 10.49 & 6444.61 \\
\hline \multirow[t]{11}{*}{ Continued } & & & & & 06-03-92 & 9.39 & 6445.71 \\
\hline & & & & & $09-10-92$ & 10.60 & 6444.50 \\
\hline & & & & & $06-02-93$ & 9.15 & 6445.95 \\
\hline & & & & & $09-08-93$ & 10.20 & 6444.90 \\
\hline & & & & & $06-01-94$ & 9.51 & 6445.59 \\
\hline & & & & & $09-07-94$ & 10.47 & 6444.63 \\
\hline & & & & & $10-26-94$ & 12.20 & 6442.90 \\
\hline & & & & & $06-02-95$ & 9.24 & 6445.86 \\
\hline & & & & & $07-25-95$ & 9.30 & 6445.80 \\
\hline & & & & & $09-17-96$ & 9.88 & 6445.22 \\
\hline & & & & & $09-23-97$ & 10.33 & 6444.77 \\
\hline
\end{tabular}

Water-level measurements and water-quality samples collected more frequently would better reflect seasonal water-level changes and help identify any seasonal water-quality component. Once a seasonal component has been identified, samples could be collected less frequently. Samples could be collected in the spring and fall, similar to the present sampling schedule. If water quality appears to be significantly impacted by facility operations, additional samples could be collected. A significant impact might include a continual increase in chemical and (or) biological constituent concentrations (approaching or exceeding a Maximum Contaminant Level (MCL) or water-quality recommendations) downgradient of the facility.

\section{Signal Mountain}

\section{Description of Facilities}

The Signal Mountain wastewater-treatment facility is located near the southeast side of Jackson Lake about 1.5 mi south of Signal Mountain Marina (fig. 10). Prior to construction of the new facility, waste was piped or trucked to a now abandoned pond (fig. 10, inset). The pond liner leaked in the now-abandoned pond, thus wastewater leaked into the underlying unconsolidated deposits. The purpose of the pond liner was to prevent wastewater from percolating into the underlying deposits. Construction of the present facility was completed in 1997 , and the facility now processes wastes generated at the marina complex. The new facility, an aerobic lagoon system, processes sewage by using aerobic digestion and is capable of treating as much as 60,000 gallons per day. Wastewater is first sent to three Hypalon-lined aeration ponds, where the water undergoes aerobic digestion; the wastewater is then piped to an infiltration pond. Some wastewater evaporates from the pond and the rest percolates downward through the unsaturated zone as recharge to ground water. An underground leach field is located next to the aeration ponds and is used only during the winter. Vegetation in the vicinity of the facility is predominately sage brush, grasses, and conifers.

Four wells (SM1, SM2, SM3, and SM5) (fig. 10), ranging in depth from 118 to $120 \mathrm{ft}$, were installed near the facility to measure water levels and to monitor ground-water quality. Well SM5 is completed in terrace deposits (Nolan and Miller, 1995). Nolan and Miller (1995, p. 36) describe SM5 as being located in a hillside site, and the geology at this site is not representative of Snake River alluvium, colluvium, or gravel, pediment, and fan deposits. A deeper well (SM4) located near the facility, about $200 \mathrm{ft}$ deep, is used for nonpotable wash water for equipment and dumpsters. Equipment and dumpsters are cleaned over a drain on a concrete pad located next to a small building (fig. 10). Wastewater produced from equipment-cleaning activities goes directly into the aeration lagoon next to the building. Construction records for wells SM4, SM5, SM6, and SM7 are listed in table 11 in Appendix I at the end of the report. Construction records are unavailable for SM1, SM2, and SM3. 


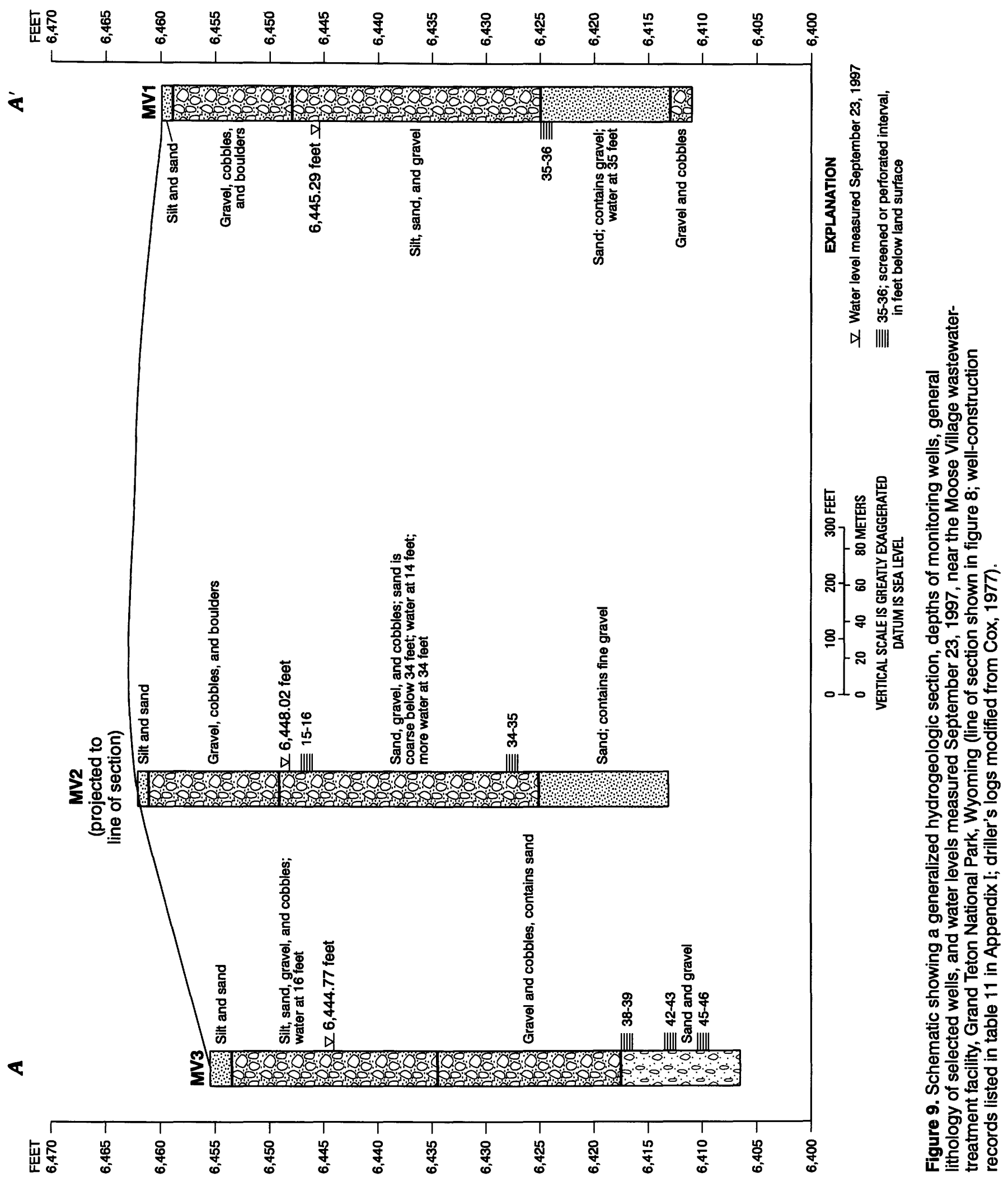




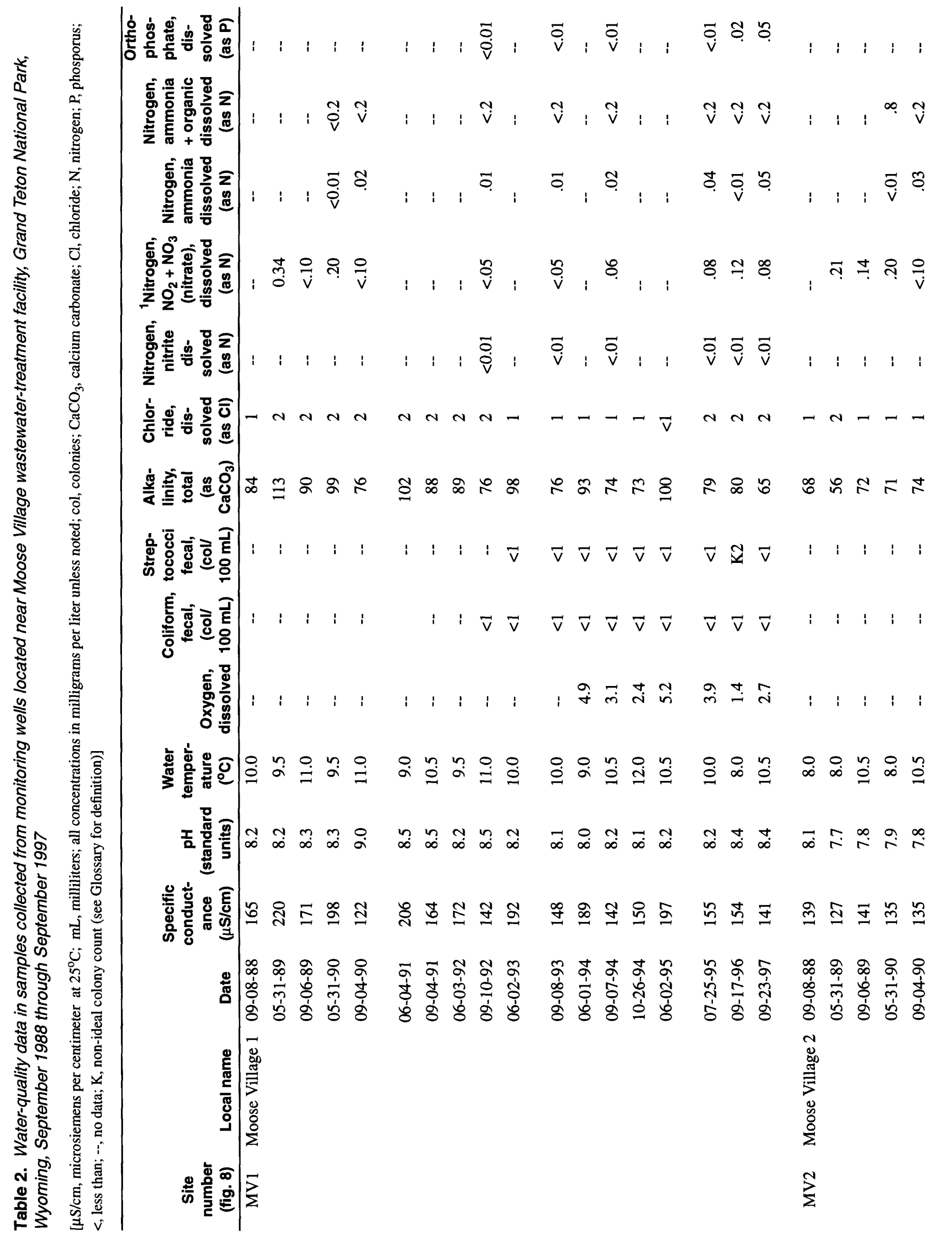




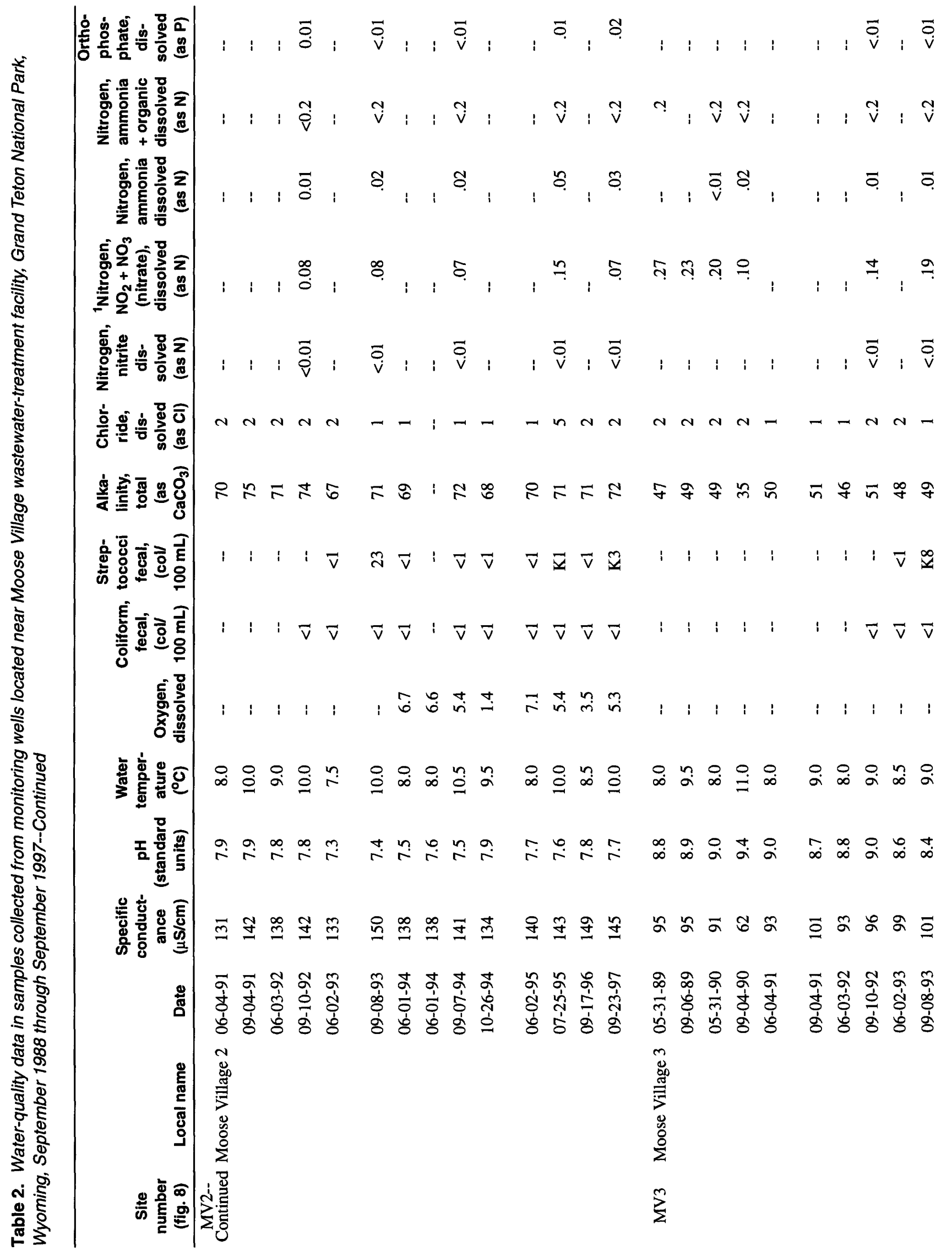




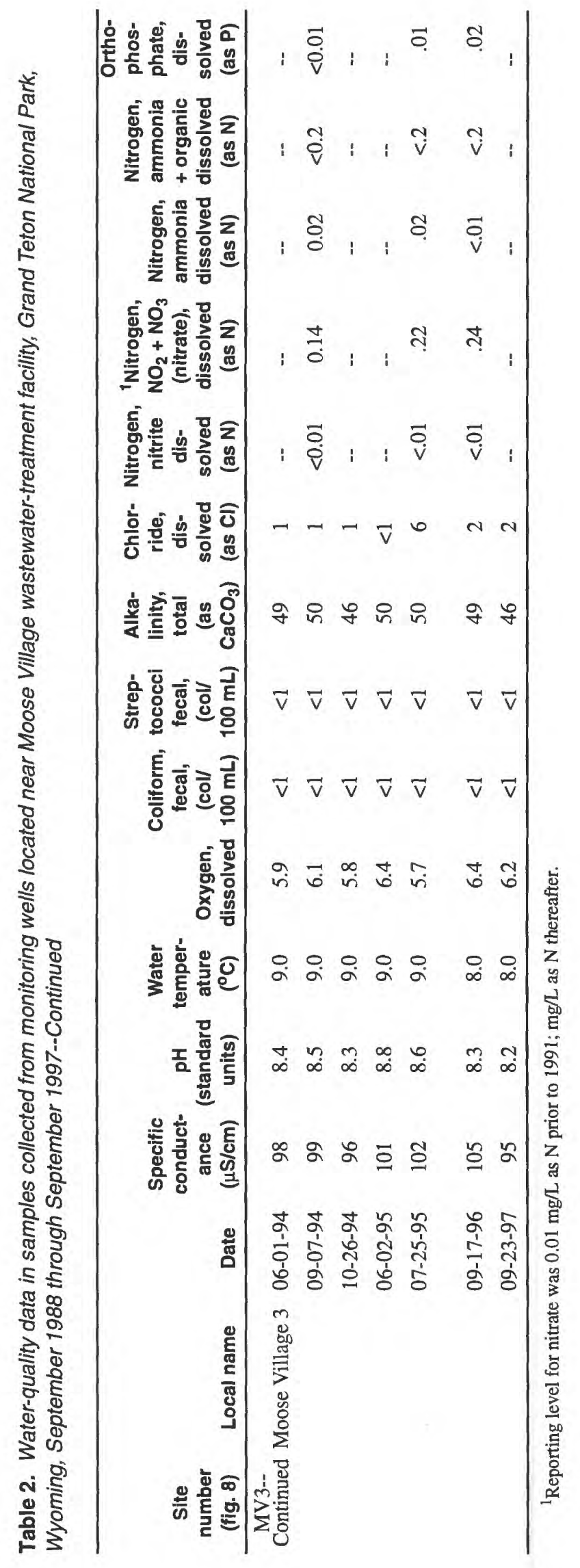




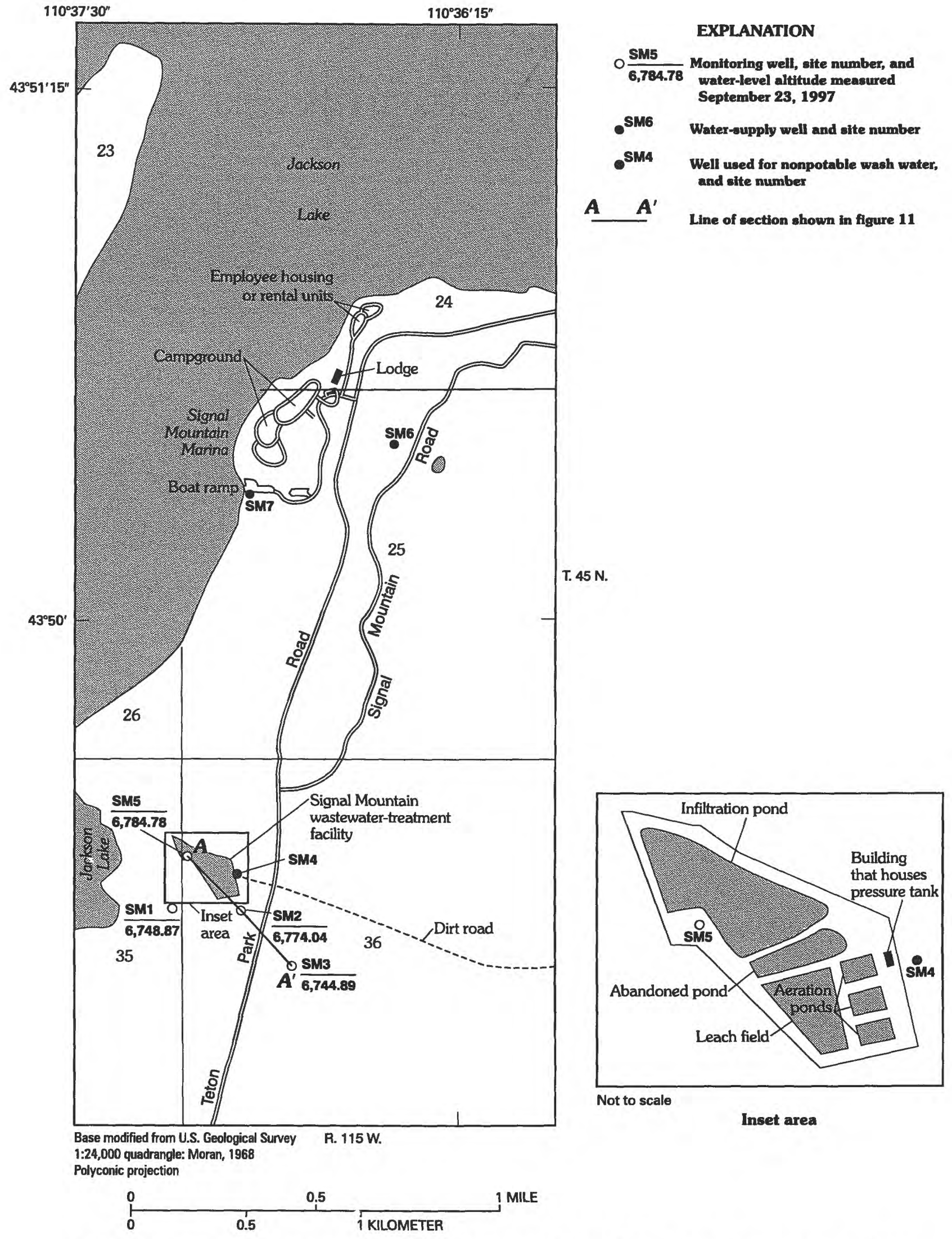

Figure 10. Location of water-supply wells and monitoring wells near Signal Mountain wastewater-treatment facility, and water levels measured September 23, 1997, Grand Teton National Park, Wyoming. 


\section{Hydrogeology}

Well logs indicate that wells SM4 and SM5 are completed in unconsolidated deposits consisting of gravel, cobbles, and limestone. Logs of wells SM4 and SM5 are shown in figure B-2 in Appendix II at the end of the report. Surficial deposits around the facility are shown as glacial drift deposits (debris of the Jackson Lake moraine) and outwash gravel by Love and others (1992). At a depth of about 70 to $80 \mathrm{ft}, \operatorname{logs}$ indicate that a limestone unit was encountered, and this unit extends to at least $200 \mathrm{ft}$. Limestone is an unlikely formation in this area (David Love, U.S. Geological Survey, oral commun., 1998). Rather than limestone, the deposit possibly could be the Huckleberry Ridge Tuff of Tertiary age (David Love, U.S. Geological Survey, oral commun., 1998). This unit is described as a gray to brown rhyolitic ash-flow tuff (Love and others, 1992). Well logs describe the limestone unit as "broken." It is unclear exactly what this term indicates; however the term could possibly mean that the unit is fractured, which would affect flow between the unconsolidated deposits and the limestone or tuff unit. Drill cuttings from these two wells are unavailable; without cores or drill cuttings it is unknown whether the unit is limestone or tuff.

Water-levels measured in the four monitoring wells at this facility ranged in depth from about $86 \mathrm{ft}$ to about $118 \mathrm{ft}$ below land surface. The northern part of the facility is only about $800 \mathrm{ft}$ from Jackson Lake, and the facility is between 90 to $100 \mathrm{ft}$ higher than the surface of the lake; thus, water levels measured in wells might be comparable to lake levels. Hydraulic properties in the limestone or tuff differ from those of the overlying unconsolidated deposits; thus, the heads measured may be more representative of the limestone or tuff than the unconsolidated deposits.

Contours on the water-table map for July 1993 (fig. 6) indicate that regional ground-water flow was away from Jackson Lake southeast toward the Snake River. Construction records are unavailable for SM1, SM2, and SM3; thus, it is unknown whether the wells are open at the bottom, similar to SM5, or have screened intervals. Therefore, an accurate assessment of the direction of ground-water flow cannot be made. Because SM4 is completed almost $80 \mathrm{ft}$ deeper than SM5, SM4 is not as useful in determining shallow lateral flow direction. Until the position of the water table is clearly defined, determining the direction of flow and assessing this site are difficult. Because of the apparent depth of the water table, monitoring any local effects the facility might have on the water table is difficult. Waterlevel measurements made in monitoring wells from September 1988 through September 1997 are listed in table 3. Water levels measured in monitoring wells September 23, 1997 are shown in figure 10. A general hydrogeologic section, the depths of selected wells, the water levels measured September 23, 1997, and the general lithology at wells SM4 and SM5 are shown in figure 11.

\section{Water Quallty}

Water-quality samples were collected from September 1988 through September 1997 from four monitoring wells (SM1, SM2, SM3, and SM5) located near the wastewater-treatment facility. One water-quality sample was collected from SM4 in September 1997. Because new liners were installed in the aeration ponds in September 1997, most of the water-quality data presented in this section might be a reflection of the groundwater quality prior to replacement of the liner. A baseline for water quality possibly has been established for comparing selected constituent concentrations after 1997 with concentrations before liner replacement. Water-quality data are listed in table 4.

The highest specific conductance values measured, ranging from 466 to $710 \mu \mathrm{S} / \mathrm{cm}$, were in samples collected from SM5 (table 4). The higher values were measured in late summer and fall. Most values ranged from 166 to $425 \mu \mathrm{S} / \mathrm{cm}$ in the other three monitoring wells and SM4. An exception was a sample collected in November 1995 from SM1 that had a conductance of $535 \mu \mathrm{S} / \mathrm{cm}$. The lowest and less variable conductance values, ranging from 166 to $267 \mu \mathrm{S} / \mathrm{cm}$, were measured in samples from wells SM2 and SM3.

Fecal coliform bacteria concentrations were less than $1 \mathrm{col} / 100 \mathrm{~mL}$ in samples collected from SM1, SM2, SM3, and SM4. Two samples collected from SM5 had concentrations of $\mathrm{K} 4 \mathrm{col} / 100 \mathrm{~mL}$ and $\mathrm{K} 18 \mathrm{col} / 100 \mathrm{~mL}$; all other samples collected had concentrations less than $1 \mathrm{col} / 100 \mathrm{~mL}$. The higher concentrations both occurred during the fall sampling period. Fecal streptococci bacteria were detected in samples collected in all monitoring wells. Streptococci bacteria were not detected in the one sample collected from SM4. Concentrations ranged from less than 1 to $\mathrm{K} 3500 \mathrm{col} / 100 \mathrm{~mL}$ in the monitoring wells. When detected, most concentrations ranged from $\mathrm{K} 1$ to $\mathrm{K} 2 \mathrm{col} / 100 \mathrm{~mL}$. The highest concentration $(\mathrm{K} 3500 \mathrm{col} / 100 \mathrm{~mL})$ was detected in the last sample collected from SM2 in September 1997. 
Table 3. Water-level measurements in monitoring wells located near Signal Mountain wastewater-treatment facility, Grand Teton National Park, Wyoming, September 1988 through September 1997

[Local number: See text describing well-numbering system. *, altitude of land surface estimated from topographic contours from U.S. Geological Survey Quadrangle series maps (1:24,000 scale); otherwise, altitude determined by level line run from benchmarks. Abbreviations: --, data not available]

\begin{tabular}{|c|c|c|c|c|c|c|c|}
\hline $\begin{array}{c}\text { Site } \\
\text { number } \\
\text { (fig. 10) }\end{array}$ & Local number & Local name & $\begin{array}{c}\text { Altitude of } \\
\text { land surface } \\
\text { (feet above } \\
\text { sea level) }\end{array}$ & $\begin{array}{l}\text { Depth of } \\
\text { well } \\
\text { (feet below } \\
\text { land } \\
\text { surface) }\end{array}$ & $\begin{array}{c}\text { Water level } \\
\text { date }\end{array}$ & $\begin{array}{c}\text { Water level } \\
\text { (feet below } \\
\text { land } \\
\text { surface) }\end{array}$ & $\begin{array}{c}\text { Water level } \\
\text { (feet above } \\
\text { sea level) }\end{array}$ \\
\hline \multirow[t]{24}{*}{ SM1 } & $45-115-36 b c c 01$ & Signal Mountain 1 & $6,836.74$ & 118 & 09-08-89 & 96.67 & 6740.37 \\
\hline & & & & & $05-31-90$ & 93.55 & 6743.19 \\
\hline & & & & & $09-04-90$ & 89.07 & 6747.67 \\
\hline & & & & & $06-04-91$ & 96.51 & 6740.23 \\
\hline & & & & & 06-04-91 & 96.26 & 6740.48 \\
\hline & & & & & 09-04-91 & 88.93 & 6747.81 \\
\hline & & & & & $06-03-92$ & 91.26 & 6745.48 \\
\hline & & & & & $09-09-92$ & 105.51 & 6731.23 \\
\hline & & & & & $06-02-93$ & -- & -- \\
\hline & & & & & $07-12-93$ & 105.44 & 6731.30 \\
\hline & & & & & $09-08-93$ & 93.94 & 6742.80 \\
\hline & & & & & $06-01-94$ & 92.59 & 6744.15 \\
\hline & & & & & 09-07-94 & 96.45 & 6740.29 \\
\hline & & & & & $10-26-94$ & 103.39 & 6733.35 \\
\hline & & & & & $06-02-95$ & 107.50 & 6729.24 \\
\hline & & & & & $07-25-95$ & 94.15 & 6742.59 \\
\hline & & & & & $11-06-95$ & 94.15 & 6742.59 \\
\hline & & & & & $06-04-96$ & 98.67 & 6738.07 \\
\hline & & & & & $08-20-96$ & 88.03 & 6748.07 \\
\hline & & & & & $09-16-96$ & 89.25 & 6747.49 \\
\hline & & & & & $05-30-97$ & 100.37 & 6736.37 \\
\hline & & & & & $07-07-97$ & 89.63 & 6746.11 \\
\hline & & & & & $08-12-97$ & 86.39 & 6750.35 \\
\hline & & & & & $09-23-97$ & 87.87 & 6748.87 \\
\hline \multirow[t]{20}{*}{ SM2 } & $45-115-36 b c d 01$ & Signal Mountain 2 & $6,890 *$ & 119 & 09-08-88 & 112.15 & 6777.85 \\
\hline & & & & & $05-31-89$ & 114.36 & 6775.64 \\
\hline & & & & & $09-08-89$ & 116.07 & 6773.93 \\
\hline & & & & & $05-31-90$ & 116.74 & 6773.26 \\
\hline & & & & & $09-04-90$ & 117.12 & 6772.88 \\
\hline & & & & & $06-04-91$ & 114.30 & 6775.70 \\
\hline & & & & & $09-04-91$ & 115.31 & 6774.69 \\
\hline & & & & & $06-03-92$ & 116.22 & 6773.78 \\
\hline & & & & & 09-09-92 & 116.08 & 6773.92 \\
\hline & & & & & $09-10-92$ & 115.98 & 6774.20 \\
\hline & & & & & $06-02-93$ & 115.80 & 6774.20 \\
\hline & & & & & $07-13-93$ & 105.39 & 6784.61 \\
\hline & & & & & $09-08-93$ & 116.10 & 6773.90 \\
\hline & & & & & $09-12-93$ & 115.25 & 6774.75 \\
\hline & & & & & $06-01-94$ & 115.41 & 6774.59 \\
\hline & & & & & $06-02-94$ & 115.33 & 6774.67 \\
\hline & & & & & $06-03-94$ & 115.20 & 6774.80 \\
\hline & & & & & $06-04-94$ & 115.25 & 6774.75 \\
\hline & & & & & $09-07-94$ & 115.42 & 6774.58 \\
\hline & & & & & 09-09-94 & 115.40 & 6774.60 \\
\hline
\end{tabular}


Table 3. Water-level measurements in monitoring wells located near Signal Mountain wastewater-treatment facility, Grand Teton National Park, Wyoming, September 1988 through September 1997--Continued

\begin{tabular}{|c|c|c|c|c|c|c|c|}
\hline $\begin{array}{c}\text { Site } \\
\text { number } \\
\text { (fig. 10) }\end{array}$ & Local number & Local name & $\begin{array}{l}\text { Altitude of } \\
\text { land surface } \\
\text { (feet above } \\
\text { sea level) }\end{array}$ & $\begin{array}{l}\text { Depth of } \\
\text { well } \\
\text { (feet below } \\
\text { land } \\
\text { surface) }\end{array}$ & $\begin{array}{c}\text { Water level } \\
\text { date }\end{array}$ & $\begin{array}{c}\text { Water level } \\
\text { (feet below } \\
\text { land } \\
\text { surface) }\end{array}$ & $\begin{array}{c}\text { Water level } \\
\text { (feet above } \\
\text { sea level) }\end{array}$ \\
\hline SM2-- & & & & & $10-26-94$ & 115.42 & 6774.58 \\
\hline \multirow[t]{10}{*}{ Continued } & & & & & $06-02-95$ & 115.87 & 6774.13 \\
\hline & & & & & $07-25-95$ & 117.41 & 6772.59 \\
\hline & & & & & $11-09-95$ & 117.21 & 6772.79 \\
\hline & & & & & 06-04-96 & 115.93 & 6774.07 \\
\hline & & & & & $08-20-96$ & 116.21 & 6773.79 \\
\hline & & & & & $09-17-96$ & 116.64 & 6773.36 \\
\hline & & & & & $05-30-97$ & 115.85 & 6774.15 \\
\hline & & & & & $07-08-97$ & 116.15 & 6773.85 \\
\hline & & & & & $08-12-97$ & 115.99 & 6774.01 \\
\hline & & & & & $09-23-97$ & 115.96 & 6774.04 \\
\hline \multirow[t]{20}{*}{ SM3 } & $45-115-36 \mathrm{cac} 01$ & Signal Mountain 3 & $6,855.14$ & 119 & 09-04-90 & 114.06 & 6741.08 \\
\hline & & & & & $06-04-91$ & dry & dry \\
\hline & & & & & 09-04-91 & 114.09 & 6741.05 \\
\hline & & & & & $06-03-92$ & 118.08 & 6737.06 \\
\hline & & & & & $09-09-92$ & dry & dry \\
\hline & & & & & $06-02-93$ & dry & dry \\
\hline & & & & & $09-08-93$ & dry & dry \\
\hline & & & & & $06-01-94$ & dry & dry \\
\hline & & & & & $09-09-94$ & dry & dry \\
\hline & & & & & $10-26-94$ & dry & dry \\
\hline & & & & & $06-02-95$ & dry & dry \\
\hline & & & & & $07-25-95$ & dry & dry \\
\hline & & & & & $11-09-95$ & dry & dry \\
\hline & & & & & $06-04-96$ & dry & dry \\
\hline & & & & & $08-20-96$ & 113.39 & 6741.75 \\
\hline & & & & & $09-17-96$ & 113.43 & 6741.71 \\
\hline & & & & & $05-30-97$ & dry & dry \\
\hline & & & & & $07-08-97$ & 115.41 & 6739.73 \\
\hline & & & & & $08-12-97$ & 111.50 & 6743.64 \\
\hline & & & & & $09-24-97$ & 110.11 & 6745.03 \\
\hline \multirow[t]{10}{*}{ SM5 } & $45-115-36 b c b 01$ & Signal Mountain 5 & $6,888.70$ & 120 & $11-06-95$ & 110.07 & 6778.63 \\
\hline & & & & & $11-09-95$ & 110.47 & 6778.23 \\
\hline & & & & & $06-03-96$ & 104.11 & 6784.59 \\
\hline & & & & & $06-04-96$ & 104.20 & 6784.50 \\
\hline & & & & & $08-20-96$ & 104.55 & 6784.15 \\
\hline & & & & & $09-16-96$ & 106.00 & 6782.70 \\
\hline & & & & & $05-30-97$ & 99.77 & 6788.93 \\
\hline & & & & & $07-08-97$ & 103.65 & 6785.05 \\
\hline & & & & & $08-12-97$ & 104.61 & 6784.09 \\
\hline & & & & & $09-23-97$ & 103.92 & 6784.78 \\
\hline
\end{tabular}




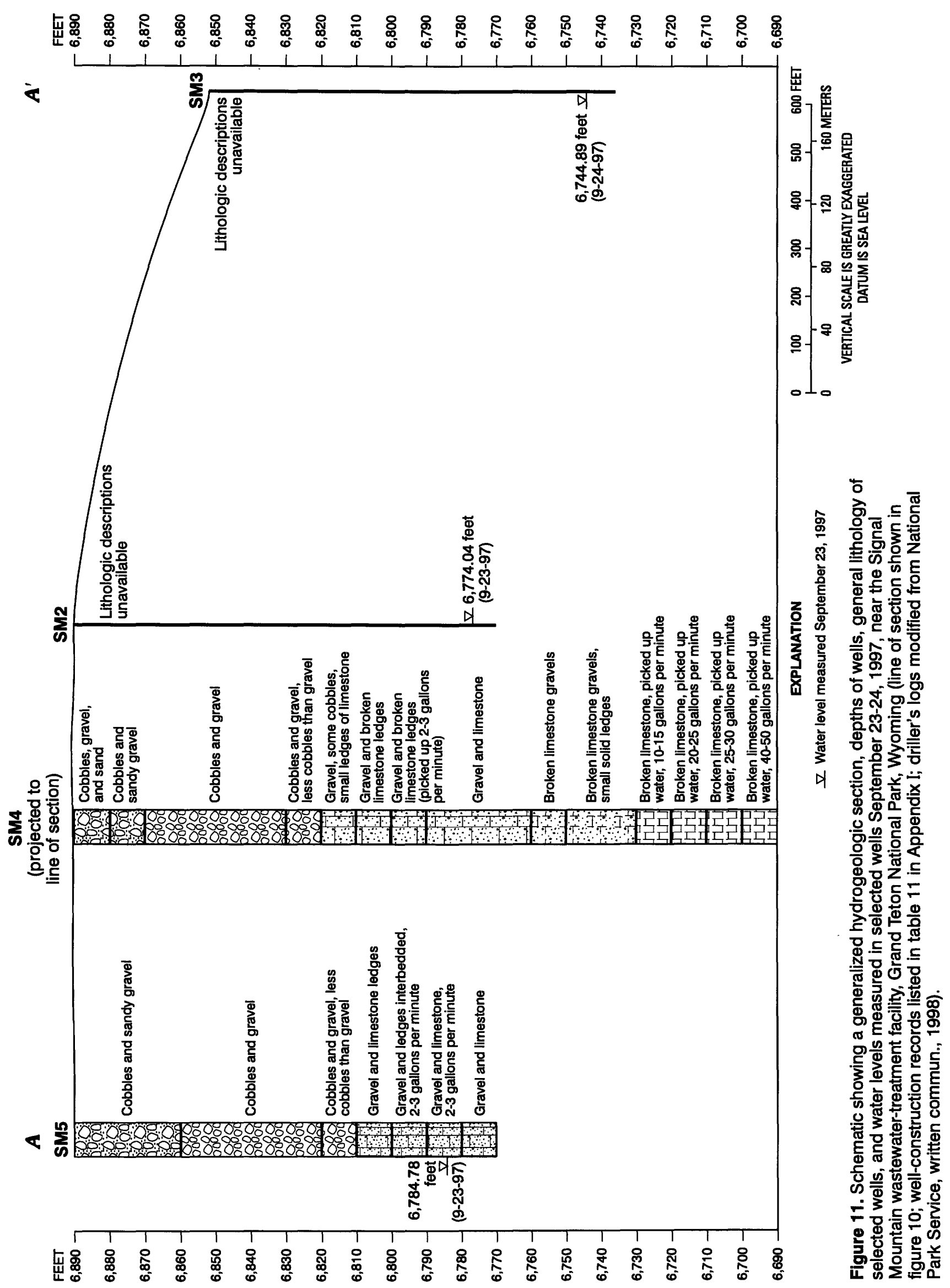




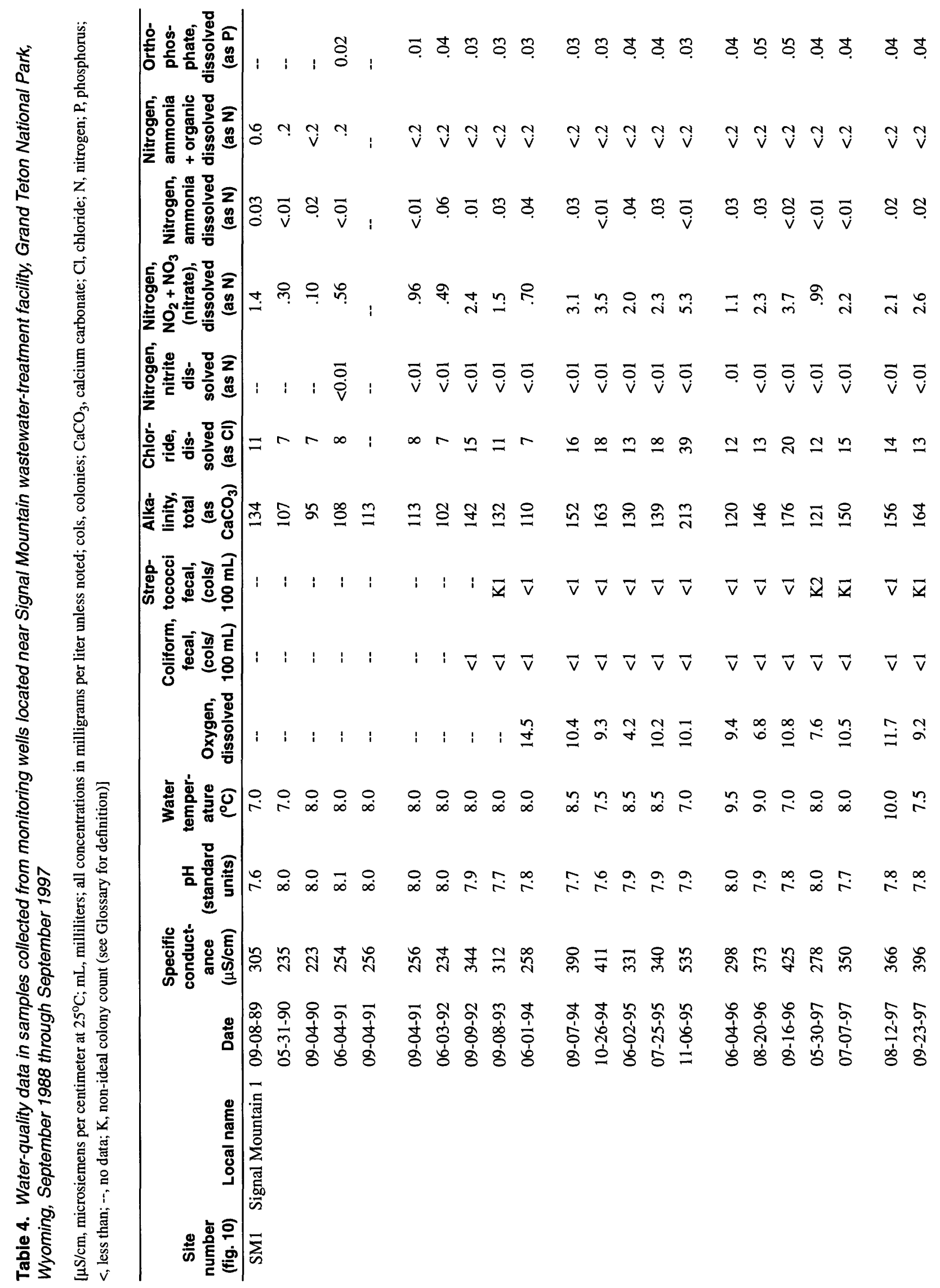




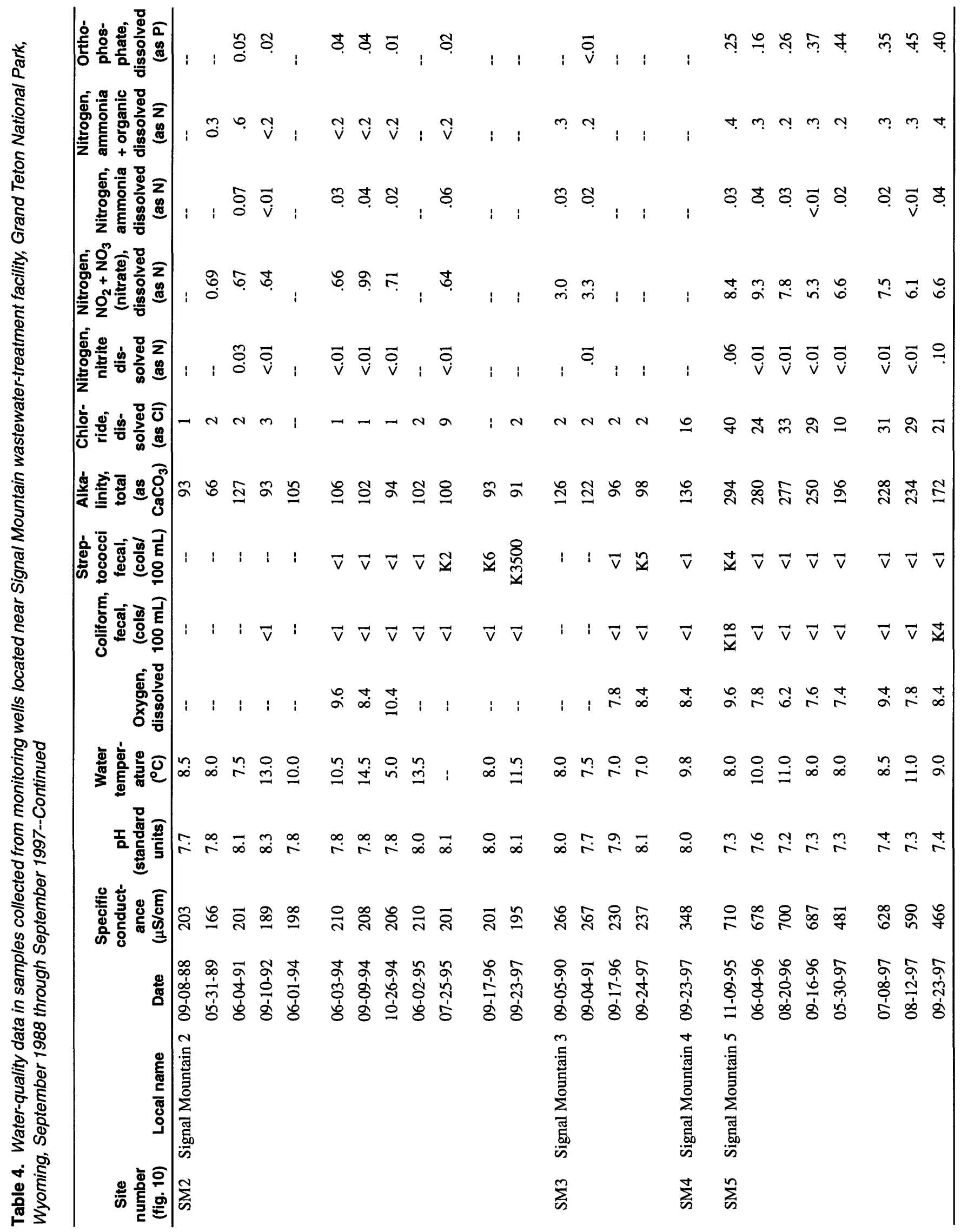


Alkalinity ranged from 66 to $294 \mathrm{mg} / \mathrm{L}$ in wells SM1, SM2, SM3, and SM5; the higher values (ranging from 172 to $294 \mathrm{mg} / \mathrm{L}$ ) were measured in samples from well SM5. Dissolved-chloride concentrations ranged from 1 to $40 \mathrm{mg} / \mathrm{L}$; the higher values were in samples collected from SM1 and SM5. Concentrations ranged from 1 to $3 \mathrm{mg} / \mathrm{L}$ in samples collected from SM2 and SM3; an exception was one sample collected from SM2 in July 1995 that had a concentration of $9 \mathrm{mg} / \mathrm{L}$. The sample collected from SM4 had a concentration of $16 \mathrm{mg} / \mathrm{L}$. For comparison, concentrations in the two water-supply wells (SM6 and SM7) located near the Signal Mountain Marina ranged from 3 to $6 \mathrm{mg} / \mathrm{L}$ (table 10). Chloride is a common constituent in wastewater.

Nitrate concentrations ranged from 0.10 to $9.3 \mathrm{mg} / \mathrm{L}$ as $\mathrm{N}$. The highest concentrations, ranging from 5.3 to $9.3 \mathrm{mg} / \mathrm{L}$ as $\mathrm{N}$, were in samples collected from SM5 during 1995-97. In comparison, nitrate concentrations ranged from 0.12 to $0.26 \mathrm{mg} / \mathrm{L}$ as $\mathrm{N}$ in samples collected from the water-supply wells during 1992-94. Nutrient samples were not collected from SM4. Nitrate concentrations greater than $3.0 \mathrm{mg} / \mathrm{L}$ as $\mathrm{N}$ generally indicate manmade contributions of nitrate (Madison and Brunett, 1985). The Maximum Contaminant Level (MCL) for nitrate established by the U.S. Environmental Protection Agency (1996) is $10 \mathrm{mg} / \mathrm{L}$ as $\mathrm{N}$. Nitrite concentrations ranged from less than 0.01 to $0.06 \mathrm{mg} / \mathrm{L}$ as $\mathrm{N}$; dissolved-ammonia concentrations from less than 0.01 to $0.07 \mathrm{mg} / \mathrm{L}$ as $\mathrm{N}$; and dissolvedammonia plus organic concentrations ranged from less than 0.2 to $0.6 \mathrm{mg} / \mathrm{L}$ as $\mathrm{N}$. Orthophosphate concentrations ranged from less than 0.01 to $0.45 \mathrm{mg} / \mathrm{L}$. For comparison, concentrations of orthophosphate ranged from 0.02 to $0.04 \mathrm{mg} / \mathrm{L}$ in the two water-supply wells (table 10, p. 59).

No observation wells are located upgradient (northwest of the wastewater-treatment facility), thus background concentrations are unavailable. Concentrations are available from samples collected from two water-supply wells, but the wells are located more than $1 \mathrm{mi}$ north and are completed at greater depths than wells near the facility. In general, concentrations of selected constituents in samples collected from SM5 are higher than in samples from SM1. Although it is possible that the high concentrations noted in this section are a result of the leaking liners, the questionable geology and water levels make it difficult to assess this site.

\section{Modifications to the Existing Monitoring-well Network}

To determine the direction of horizontal and vertical ground-water flow and to better monitor water quality near the wastewater-treatment facility, three clusters of wells (three wells per cluster) installed near the eastern, southern, and western border of the facility would be useful. Because the geology near the site is in question, new wells would provide cores or cuttings, from which the geology can be better described. Well logs indicate that water was encountered between 90 and $100 \mathrm{ft}$, just below where the limestone or tuff was encountered. A well completed at the base of the unconsolidated deposits would determine whether the water table is in unconsolidated deposits or in the underlying unit. Wells with screened intervals completed at different depths would allow any vertical component of flow to be measured and water-quality changes to be assessed. The additional wells would also help determine the hydraulic relations between the unconsolidated deposits and the underlying limestone or tuff. A cluster of wells installed northwest of the facility would help determine background concentrations of selected constituents and help determine if concentrations observed in samples are a result of facility operations. Ground-water flow direction near the facility would be better defined by collecting waterlevel measurements in the newly installed wells. Wells SM1, SM2, SM3, SM4, and SM5 would be available for additional sampling if necessary. An additional well installed between the facility and Jackson Lake could help determine how lake levels are associated with the water table.

Water-level measurements and water-quality samples collected more frequently would better reflect seasonal water-level changes and help identify any seasonal water-quality component. Once a seasonal component has been identified, samples could be collected less frequently. Samples could be collected in the spring and fall, similar to the present sampling schedule. If water quality appears to be significantly impacted by facility operations, additional samples could be collected. Again, a significant impact might include a continual increase in chemical and (or) biological constituent concentrations (approaching MCLs or water-quality recommendations). 


\section{Colter Bay Village}

\section{Description of Facilities}

The Colter Bay Village wastewater-treatment facility (fig. 12) processes effuent from Jackson Lake Lodge (fig. 1) and Colter Bay Village. The facility is about $1 \mathrm{mi}$ southeast of Colter Bay Village, about $1 \mathrm{mi}$ east of Jackson Lake, and about $\mathbf{0 . 6}$ mi northeast of Swan Lake. The original facility, constructed in 1955 , was designed to process 52,000 gallons per day. Upgraded in 1978, the facility now consists of four aeration ponds, two settling ponds, and two infiltration ponds and can treat 300,000 gallons per day.

The topography south of the facility is essentially flat. Vegetation consists of conifers, aspens, willows, and sedges. Surficial deposits south of the facility as shown by Love and others (1992), indicate that swamp deposits and glacial-drift deposits dominate the landscape. Swamp deposits are described as dark-gray and brown clay, silt, and fine sand that are rich in debris (Love and others, 1992). The thickness of the swamp and glacial-drift deposits is unknown. The swamp deposits are located primarily south and southeast of the facility (Love and others, 1992). Glacial drift deposits dominate the area west and southwest of the facility; two isolated glacial-drift deposits also are mapped directly south of the facility (Love and others, 1992).

Wastewater is pumped to two spray-aeration ponds (fig. 12, inset) where the wastewater is saturated with oxygen. Wastewater is then pumped from the spray-aeration ponds to two large aeration ponds where it undergoes aerobic digestion; the wastewater is then pumped to two settling ponds. From the settling ponds, the wastewater is piped to two infiltration ponds.

Five monitoring wells (CB1, CB2, CB3, CB4, and CB5), ranging in depth from 32 to $44 \mathrm{ft}$, are located near the facility (fig. 12). An additional well (CB6), $5 \mathrm{ft}$ in depth, was installed in a swampy area near the southern part of the facility. Construction records for the six wells are listed in table 11 in Appendix I at the end of the report.

\section{Hydrogeology}

Well logs indicate that the monitoring wells near the facility are completed in unconsolidated deposits consisting of clay, silt, sand, and gravel. Love and others (1992) indicate the facility is built on surficial deposits consisting of colluvium. Well logs of CB1, CB2, CB3, CB4, and CB5 are shown in figure B-4 in Appendix II at the end of the report. The logs of CB1, CB2, and CB3 show that silty low-permeability zones are present and might act as confining or semiconfining units. The areal extent of these zones is unknown.

Water-level measurements made in monitoring wells from September 1988 through September 1997 are listed in table 5. Water levels measured September 24,1997 are shown in figure 12. A generalized hydrogeologic section, the depths of selected monitoring wells, the water level measured September 24, 1997 , and the general lithology at five monitoring wells located around the facility are shown in figure 13. Where wastewater-treatment facilities overlie a shallow water table, the possibility exists for ground-water mounding to occur beneath the facility at different times of the year. Contours on the water-table map for July 1993 (fig. 6) indicate that the regional groundwater flow direction was southwest to south.

Swan Lake is about $1900 \mathrm{ft}$ from Jackson Lake. The interaction between the two lakes is unknown. The interaction between Swan Lake and the small cluster of lakes a few hundred feet to the northeast also is unknown.

Two shallow wells installed in 1995 along the eastern shore of Swan Lake, about $1860 \mathrm{ft}$ apart (fig. 12) were completed to depths of $9 \mathrm{ft}$ (SL2) and $13 \mathrm{ft}$ (SL1). Drill cuttings or cores are unavailable for the two shallow wells. A staff gage was installed at Swan Lake to compare altitudes of Swan Lake to water levels measured in the two wells; the comparisons are shown in figure 14. Water levels measured in SL1 indicate that water apparently flows from the lake to the ground-water system in the area of SL1, and that ground water flows to the lake in the area of SL2.

\section{Water Quality}

Water-quality samples were collected from five monitoring wells (CB1, CB2, CB3, CB4, and CB5) from September 1988 through September 1997, and from the shallow well CB6 during 1995-97. Waterquality data are listed in table 6 .

Fecal coliform bacteria concentrations were less than $1 \mathrm{col} / 100 \mathrm{~mL}$ in samples collected from wells CB1, CB2, and CB3. Concentrations of $K 1 \mathrm{col} / 100 \mathrm{~mL}$ or greater were detected in wells CB4, CB5, and CB6. The highest concentrations were in samples collected 


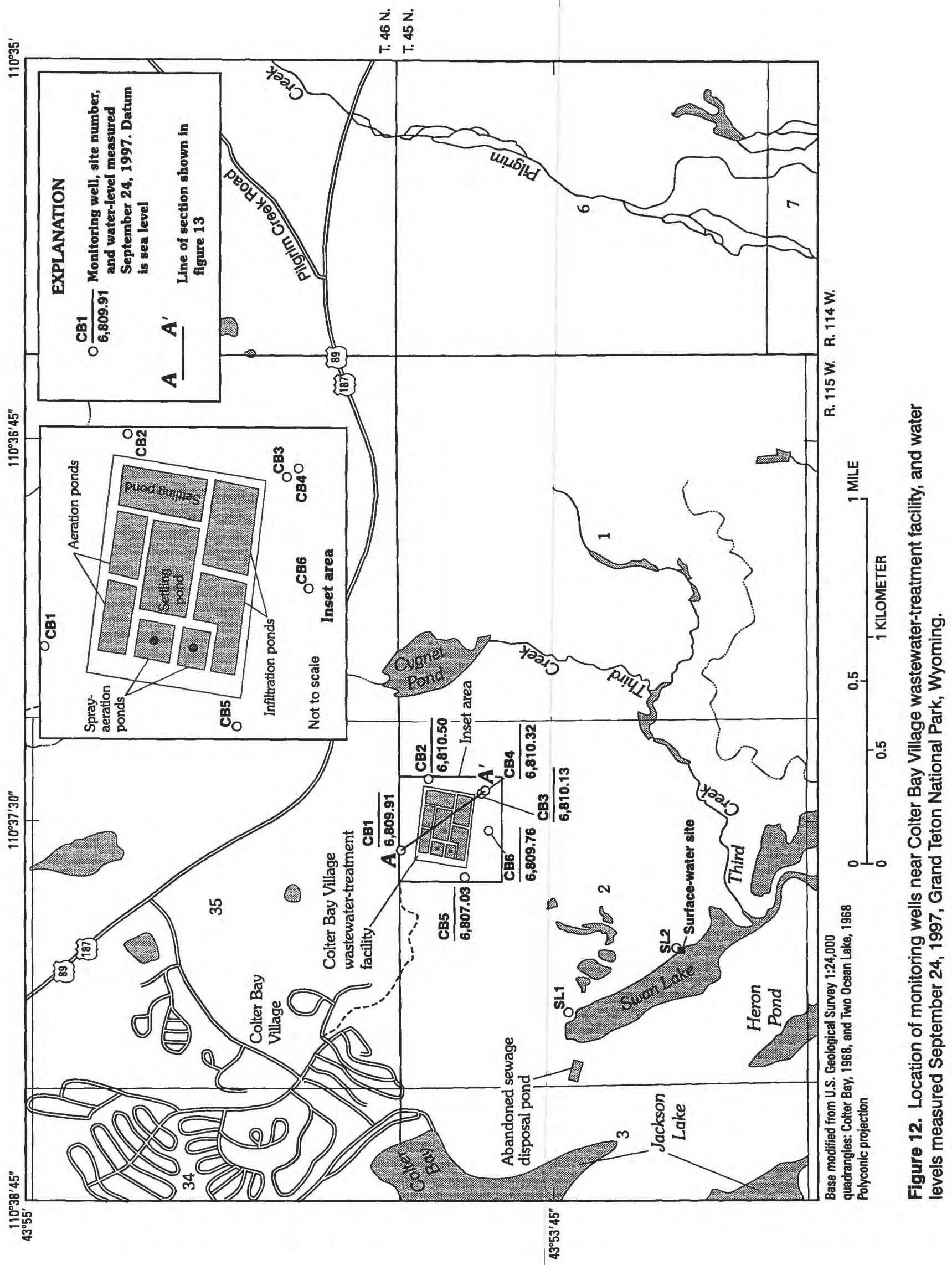


Table 5. Water-level measurements in monitoring wells located near Colter Bay Village wastewater-treatment facility, Grand Teton National Park, Wyoming, September 1988 through September 1997

[Local number: See text describing well-numbering system. *, altitude of land surface estimated from topographic contours from U.S. Geological Survey Quadrangle series maps (1:24,000 scale); otherwise, altitude of land surface determined by level line run from benchmarks.]

\begin{tabular}{|c|c|c|c|c|c|c|c|}
\hline $\begin{array}{c}\text { Site } \\
\text { number } \\
\text { (fig. 12) }\end{array}$ & Local number & Local name & $\begin{array}{l}\text { Altitude of land } \\
\text { surface } \\
\text { (feet above } \\
\text { sea level) }\end{array}$ & $\begin{array}{l}\text { Depth of well } \\
\text { (feet below } \\
\text { land surface) }\end{array}$ & $\begin{array}{c}\text { Water level } \\
\text { date }\end{array}$ & $\begin{array}{l}\text { Water level } \\
\text { (feet below } \\
\text { land surface) }\end{array}$ & $\begin{array}{c}\text { Water level } \\
\text { (feet above } \\
\text { sea level) }\end{array}$ \\
\hline \multirow[t]{24}{*}{$\mathrm{CB} 1$} & $45-115-02 a b b 01$ & Colter Bay 1 & $6,820^{*}$ & 37 & $09-07-88$ & 11.43 & 6808.57 \\
\hline & & & & & $06-01-89$ & 5.97 & 6814.03 \\
\hline & & & & & 09-07-89 & 10.67 & 6809.33 \\
\hline & & & & & $05-30-90$ & 8.23 & 6811.77 \\
\hline & & & & & $09-05-90$ & 10.88 & 6809.12 \\
\hline & & & & & $06-05-91$ & 7.04 & 6812.96 \\
\hline & & & & & 09-05-91 & 10.63 & 6809.37 \\
\hline & & & & & $06-04-92$ & 10.21 & 6809.79 \\
\hline & & & & & $09-09-92$ & 10.96 & 6809.04 \\
\hline & & & & & $06-03-93$ & 5.13 & 6814.87 \\
\hline & & & & & $09-09-93$ & 10.42 & 6809.58 \\
\hline & & & & & $06-02-94$ & 9.70 & 6810.03 \\
\hline & & & & & 09-08-94 & 11.30 & 6808.70 \\
\hline & & & & & $10-27-94$ & 11.62 & 6808.38 \\
\hline & & & & & $06-03-95$ & 4.53 & 6815.47 \\
\hline & & & & & $07-26-95$ & 9.19 & 6810.81 \\
\hline & & & & & $11-08-95$ & 11.04 & 6809.00 \\
\hline & & & & & 06-04-96 & 3.77 & 6816.23 \\
\hline & & & & & $08-21-96$ & 10.53 & 6809.47 \\
\hline & & & & & $09-18-96$ & 10.66 & 6809.34 \\
\hline & & & & & $05-28-97$ & .71 & 6819.29 \\
\hline & & & & & $07-10-97$ & 8.47 & 6811.53 \\
\hline & & & & & $08-13-97$ & 9.13 & 6810.87 \\
\hline & & & & & $09-24-97$ & 10.09 & 6809.91 \\
\hline \multirow[t]{20}{*}{$\mathrm{CB} 2$} & 45-115-02aab01 & Colter Bay 2 & $6,820^{*}$ & 36 & $09-07-88$ & 11.37 & 6808.63 \\
\hline & & & & & $06-01-89$ & 6.45 & 6813.55 \\
\hline & & & & & 09-07-89 & 10.57 & 6809.43 \\
\hline & & & & & $05-30-90$ & 8.25 & 6811.75 \\
\hline & & & & & $09-05-90$ & 10.62 & 6809.38 \\
\hline & & & & & $06-05-91$ & 7.12 & 6812.88 \\
\hline & & & & & $09-05-91$ & 10.10 & 6809.90 \\
\hline & & & & & $06-04-92$ & 9.95 & 6810.05 \\
\hline & & & & & $09-09-92$ & 10.31 & 6809.69 \\
\hline & & & & & $06-03-93$ & 5.75 & 6814.25 \\
\hline & & & & & 09-09-93 & 10.44 & 6809.56 \\
\hline & & & & & $06-02-94$ & 9.39 & 6810.61 \\
\hline & & & & & $09-08-94$ & 11.42 & 6808.58 \\
\hline & & & & & $10-27-94$ & 11.61 & 6808.39 \\
\hline & & & & & 06-03-95 & 5.46 & 6814.54 \\
\hline & & & & & $07-26-95$ & 9.33 & 6810.67 \\
\hline & & & & & $11-08-95$ & 11.04 & 6808.96 \\
\hline & & & & & $06-04-96$ & 5.03 & 6814.97 \\
\hline & & & & & $08-21-96$ & 10.69 & 6809.31 \\
\hline & & & & & $09-17-96$ & 10.63 & 6809.37 \\
\hline
\end{tabular}


Table 5. Water-level measurements in monitoring wells located near Colter Bay Village wastewater-treatment facility, Grand Teton National Park, Wyoming, September 1988 through September 1997--Continued

\begin{tabular}{|c|c|c|c|c|c|c|c|}
\hline $\begin{array}{c}\text { Site } \\
\text { number } \\
\text { (fig. 12) }\end{array}$ & Local number & Local name & $\begin{array}{l}\text { Altitude of land } \\
\text { surface } \\
\text { (feet above } \\
\text { sea level) }\end{array}$ & $\begin{array}{l}\text { Depth of well } \\
\text { (feet below } \\
\text { land surface) }\end{array}$ & $\begin{array}{c}\text { Water level } \\
\text { date }\end{array}$ & $\begin{array}{l}\text { Water level } \\
\text { (feet below } \\
\text { land surface) }\end{array}$ & $\begin{array}{c}\text { Water level } \\
\text { (feet above } \\
\text { sea level) }\end{array}$ \\
\hline \multirow[t]{3}{*}{ Continued } & & & & & $07-10-97$ & 8.39 & 6811.61 \\
\hline & & & & & $08-13-97$ & 8.91 & 6811.09 \\
\hline & & & & & 09-24-97 & 9.90 & 6810.10 \\
\hline \multirow{15}{*}{ CB3 } & & & & & $06-01-89$ & 2.77 & 6812.33 \\
\hline & & & & & $09-07-89$ & 5.62 & 6809.48 \\
\hline & & & & & $05-30-90$ & 3.78 & 6811.32 \\
\hline & & & & & $09-05-90$ & 5.60 & 6809.50 \\
\hline & & & & & $06-05-91$ & 3.07 & 6812.03 \\
\hline & & & & & $09-09-93$ & 5.49 & 6809.61 \\
\hline & & & & & $06-02-94$ & 4.65 & 6810.45 \\
\hline & & & & & $09-08-94$ & 6.44 & 6808.66 \\
\hline & & & & & $10-27-94$ & 6.60 & 6808.50 \\
\hline & & & & & 06-03-95 & 2.46 & 6812.64 \\
\hline & & & & & $07-26-95$ & 4.51 & 6810.59 \\
\hline & & & & & $11-08-95$ & 6.06 & 6809.04 \\
\hline & & & & & $06-04-96$ & 2.35 & 6812.75 \\
\hline & & & & & $08-21-96$ & 5.85 & 6809.25 \\
\hline & & & & & $09-18-96$ & 5.59 & 6809.51 \\
\hline \multirow{17}{*}{ CB4 } & & & & & $05-30-90$ & 3.38 & 6811.52 \\
\hline & & & & & $09-05-90$ & 5.21 & 6809.69 \\
\hline & & & & & $06-05-91$ & 2.75 & 6812.15 \\
\hline & & & & & 09-05-91 & 4.85 & 6810.05 \\
\hline & & & & & $06-04-92$ & 4.74 & 6813.16 \\
\hline & & & & & 09-09-92 & 5.00 & 6809.90 \\
\hline & & & & & 06-03-93 & 2.19 & 6812.71 \\
\hline & & & & & 09-09-93 & 5.12 & 6809.78 \\
\hline & & & & & $06-02-94$ & 4.27 & 6810.63 \\
\hline & & & & & 09-08-94 & 6.05 & 6808.85 \\
\hline & & & & & $10-27-94$ & 6.20 & 6808.70 \\
\hline & & & & & $06-03-95$ & 2.24 & 6812.66 \\
\hline & & & & & $07-26-95$ & 4.15 & 6810.75 \\
\hline & & & & & $11-08-95$ & 5.66 & 6809.24 \\
\hline & & & & & $06-04-96$ & 2.15 & 6812.75 \\
\hline & & & & & $08-21-96$ & 5.45 & 6809.45 \\
\hline & & & & & $09-18-96$ & 5.19 & 6809.71 \\
\hline
\end{tabular}


Tabie 5. Water-level measurements in monitoring wells located near Colter Bay Village wastewater-treatment facility, Grand Teton National Park, Wyoming, September 1988 through September 1997--Continued

\begin{tabular}{|c|c|c|c|c|c|c|c|}
\hline $\begin{array}{c}\text { Site } \\
\text { number } \\
\text { (fig. 12) }\end{array}$ & Local number & Local name & $\begin{array}{l}\text { Altitude of land } \\
\text { surface } \\
\text { (feet above } \\
\text { sea level) }\end{array}$ & $\begin{array}{l}\text { Depth of well } \\
\text { (feet below } \\
\text { land surface) }\end{array}$ & $\begin{array}{c}\text { Water level } \\
\text { date }\end{array}$ & $\begin{array}{l}\text { Water level } \\
\text { (feet below } \\
\text { land surface) }\end{array}$ & $\begin{array}{c}\text { Water level } \\
\text { (feet above } \\
\text { sea level) }\end{array}$ \\
\hline \multirow[t]{3}{*}{ Continued } & & & & & $07-10-97$ & 3.50 & 6811.40 \\
\hline & & & & & $08-13-97$ & 3.65 & 6811.25 \\
\hline & & & & & $09-24-97$ & 4.58 & 6810.32 \\
\hline \multirow{15}{*}{ CB5 } & & & & & $06-01-89$ & 2.67 & 6807.53 \\
\hline & & & & & 09-07-89 & 3.80 & 6806.40 \\
\hline & & & & & $05-30-90$ & 3.12 & 6807.08 \\
\hline & & & & & $09-05-90$ & 3.86 & 6806.34 \\
\hline & & & & & $06-05-91$ & 2.94 & 6807.26 \\
\hline & & & & & $09-09-93$ & 3.68 & 6806.52 \\
\hline & & & & & $06-02-94$ & 2.66 & 6807.54 \\
\hline & & & & & $09-08-94$ & 4.29 & 6805.91 \\
\hline & & & & & $10-27-94$ & 4.15 & 6806.05 \\
\hline & & & & & $06-03-95$ & 2.59 & 6807.61 \\
\hline & & & & & $07-26-95$ & 3.29 & 6806.91 \\
\hline & & & & & $11-08-95$ & 3.74 & 6806.46 \\
\hline & & & & & $06-04-96$ & 2.55 & 6807.65 \\
\hline & & & & & $08-21-96$ & 3.67 & 6806.53 \\
\hline & & & & & $09-18-96$ & 3.58 & 6806.62 \\
\hline \multirow{7}{*}{ CB6 } & & & & & $11-08-95$ & 3.40 & 6808.70 \\
\hline & & & & & $06-04-96$ & -.35 & 6812.45 \\
\hline & & & & & $08-21-96$ & 3.08 & 6809.02 \\
\hline & & & & & $09-18-96$ & 2.76 & 6809.34 \\
\hline & & & & & $05-28-97$ & -.53 & 6812.63 \\
\hline & & & & & $07-10-97$ & 1.17 & 6810.93 \\
\hline & & & & & $08-13-97$ & 1.09 & 6811.01 \\
\hline \multirow[t]{5}{*}{ SL1 } & $45-115-02$ bdd 01 & Swan Lake 1 & $6,800 *$ & 12 & $06-06-96$ & 5.56 & 6794.44 \\
\hline & & & & & $08-21-96$ & 10.95 & 6789.05 \\
\hline & & & & & $09-18-96$ & 9.50 & 6790.50 \\
\hline & & & & & $05-29-97$ & 6.70 & 6793.30 \\
\hline & & & & & $07-10-97$ & 11.27 & 6788.73 \\
\hline \multirow[t]{5}{*}{ SL2 } & $45-115-02 \mathrm{cdb} 01$ & Swan Lake 2 & $6,800^{*}$ & 9 & $06-05-96$ & -.45 & 6800.45 \\
\hline & & & & & $08-21-96$ & 1.58 & 6798.42 \\
\hline & & & & & $09-18-96$ & 1.29 & 6798.71 \\
\hline & & & & & $05-29-97$ & -.91 & 6800.91 \\
\hline & & & & & $07-10-97$ & .46 & 6799.54 \\
\hline
\end{tabular}




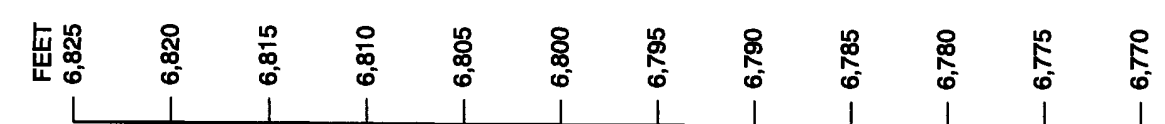

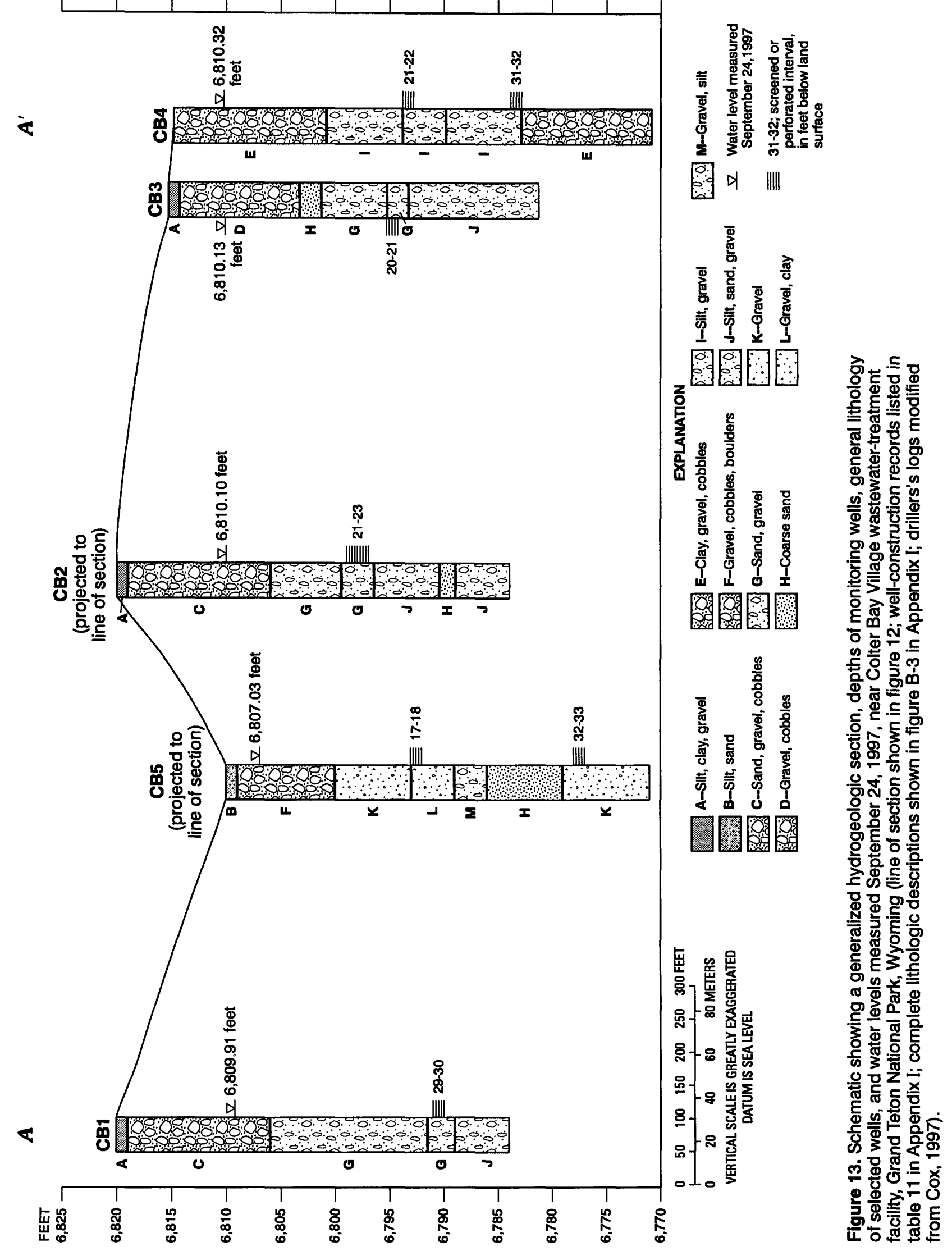




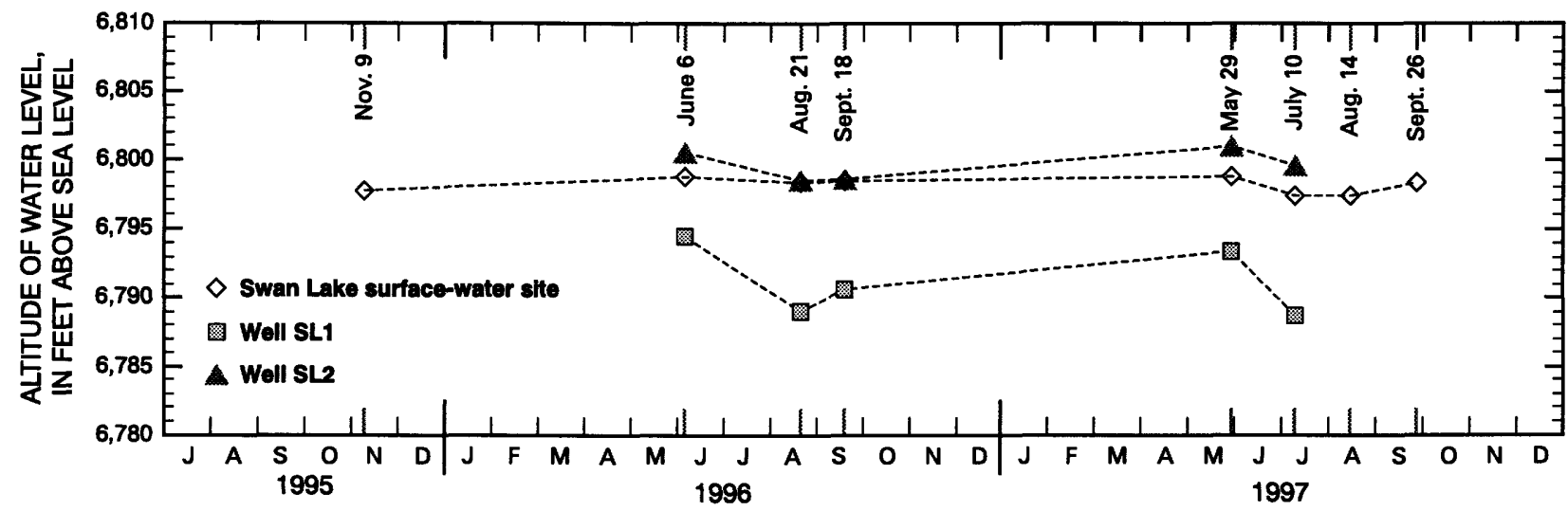

Figure 14. Altitude of Swan Lake in comparison to water-level measurements in wells SL1 and SL2 near Swan Lake, Grand Teton National Park, Wyoming. Location of Swan Lake and wells shown in figure 12. No measurements between dates shown.

from CB5. Five samples had concentrations ranging from $\mathrm{K} 1$ to $\mathrm{K} 9 \mathrm{col} / 100 \mathrm{~mL}$. Fecal streptococci bacteria concentrations ranged from less than 1 to $56 \mathrm{col} / 100 \mathrm{~mL}$ in samples collected from all six wells. The highest concentration was detected in a sample collected from CB2 July 26, 1995.

Water-quality data in samples collected from wells $\mathrm{CB} 1, \mathrm{CB} 2, \mathrm{CB} 3, \mathrm{CB} 4$, and $\mathrm{CB} 5$ indicate that reducing conditions exist in the ground water sampled from well CB5. The areal and vertical extent of the reducing zone is unknown. Geochemical evidence supporting this interpretation includes concentrations of dissolved oxygen, alkalinity, nitrate, and dissolved ammonia (table 6). Dissolved-oxygen concentrations in samples collected from CB1, CB2, CB3, and CB4 ranged from 2.4 to $11.6 \mathrm{mg} / \mathrm{L}$. In contrast, dissolvedoxygen concentrations in samples from CB5 ranged from less than 1 to $1.4 \mathrm{mg} / \mathrm{L}$; most concentrations (13 of 14 samples) were less than $1 \mathrm{mg} / \mathrm{L}$. Alkalinity concentrations in samples collected from CB1, CB2, CB3, and $\mathrm{CB} 4$ ranged from 16 to $52 \mathrm{mg} / \mathrm{L}$ (expressed as $\mathrm{CaCO} 3$ ), whereas concentrations in samples from $\mathrm{CB} 5$ ranged from 51 to $182 \mathrm{mg} / \mathrm{L}$. Nitrate concentrations in samples collected from $\mathrm{CB} 1, \mathrm{CB} 2, \mathrm{CB} 3$, and $\mathrm{CB} 4$ ranged from less than 0.10 to $0.84 \mathrm{mg} / \mathrm{L}$ as $\mathrm{N}$. Nitrate concentrations in samples from CB5 were never greater than $0.08 \mathrm{mg} / \mathrm{L}$ as $\mathrm{N}$, and 17 of the 23 samples collected were less than the reporting level $(0.10 \mathrm{mg} / \mathrm{L}$ as $\mathrm{N}$ prior to 1991 ; $0.05 \mathrm{mg} / \mathrm{L}$ as $\mathrm{N}$ thereafter). Dissolved-ammonia concentrations in samples collected from CB1, CB2, CB3, and CB4 ranged from less than 0.01 to $0.7 \mathrm{mg} / \mathrm{L}$ as $\mathrm{N}$. Concentrations of dissolved ammonia in samples from CB5 were higher, ranging from 0.62 to $4.8 \mathrm{mg} / \mathrm{L}$ as $\mathrm{N}$.
All samples collected from CB5 for analysis of ammonia contained detectable quantities of this constituent.

Additional characteristics that indicate effluent is reaching the ground water are specific conductance, dissolved chloride, and orthophosphate. Specificconductance measured in samples collected from CB1, CB2, CB3, and CB4 ranged from 48 to $109 \mu \mathrm{S} / \mathrm{cm}$. In comparison, concentrations in samples collected from CB5 ranged from 131 to $642 \mu \mathrm{S} / \mathrm{cm}$. Dissolved-chloride concentrations in samples collected from $\mathrm{CB} 1, \mathrm{CB} 2$, $\mathrm{CB} 3$, and CB4 ranged from less than 1 to $6 \mathrm{mg} / \mathrm{L}$, whereas concentrations in samples collected from CB5 ranged from 7 to $104 \mathrm{mg} / \mathrm{L}$. Orthophosphate concentrations in samples collected from CB1, CB2, CB3, and CB4 ranged from less than 0.01 to $0.05 \mathrm{mg} / \mathrm{L}$, whereas concentrations in samples from CB5 ranged from less than 0.01 to $2.1 \mathrm{mg} / \mathrm{L}$.

Overall, the contrasts between water-quality data in samples collected from wells $\mathrm{CB} 1, \mathrm{CB} 2, \mathrm{CB} 3$, and CB4 and water-quality data in samples collected from well $\mathrm{CB} 5$ are striking. Boxplots for wells $\mathrm{CB} 1$ and $\mathrm{CB} 5$ illustrating these contrasts are shown in figure 15. As discussed in the previous paragraph, specific conductance and concentrations of ammonia are high in samples collected from $\mathrm{CB} 5$ in relation to concentrations of the same constituents in samples from $\mathrm{CB} 1, \mathrm{CB} 2, \mathrm{CB} 3$, and CB4. A similar relation is evident for concentrations of alkalinity and dissolved chloride. Conversely, concentrations of nitrate in samples collected from $\mathrm{CB} 1$ (as well as CB2, CB3, and CB4) are high in relation to concentrations of nitrate in samples collected from CB5; a similar relation exists for concentrations of dissolved oxygen. 


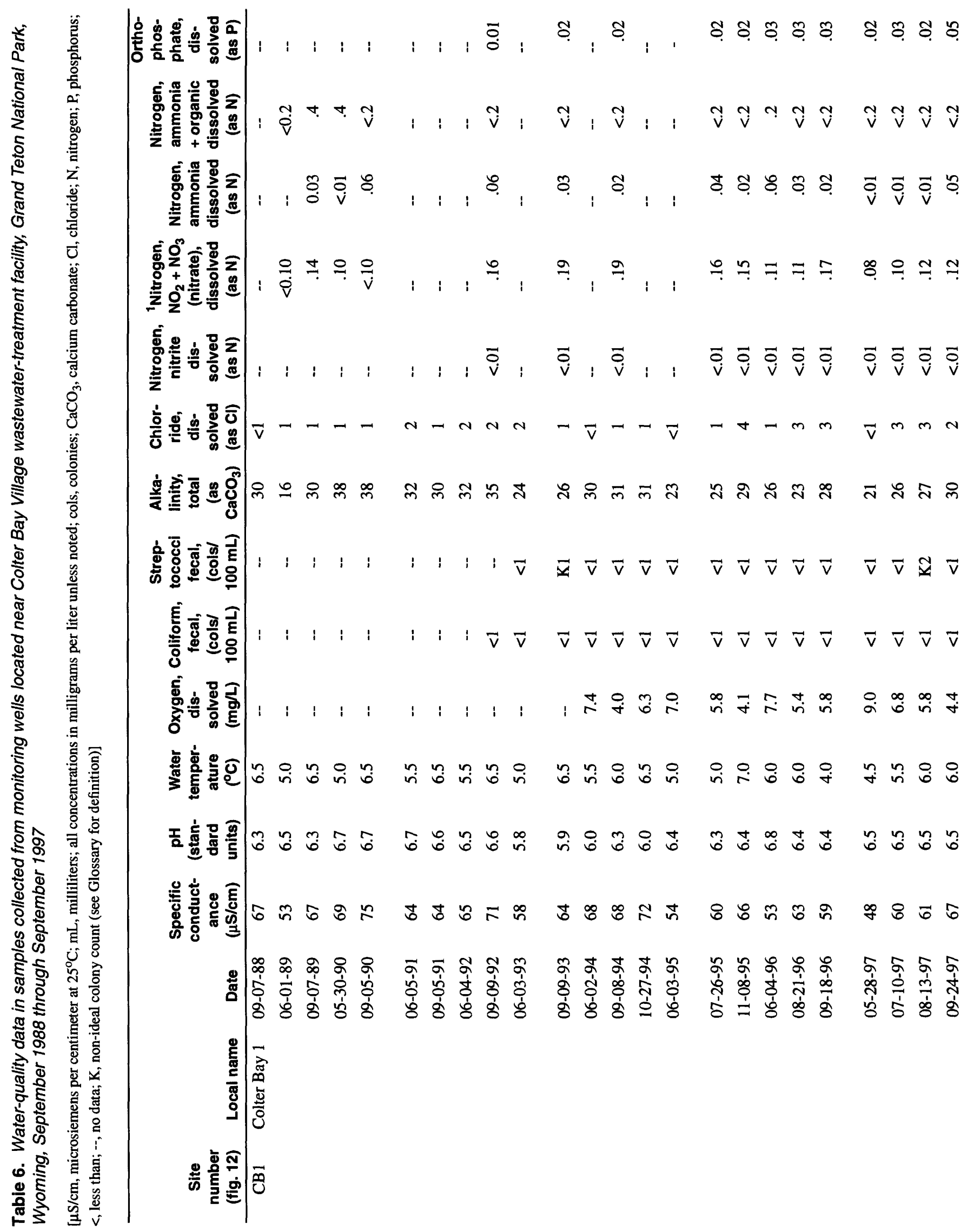




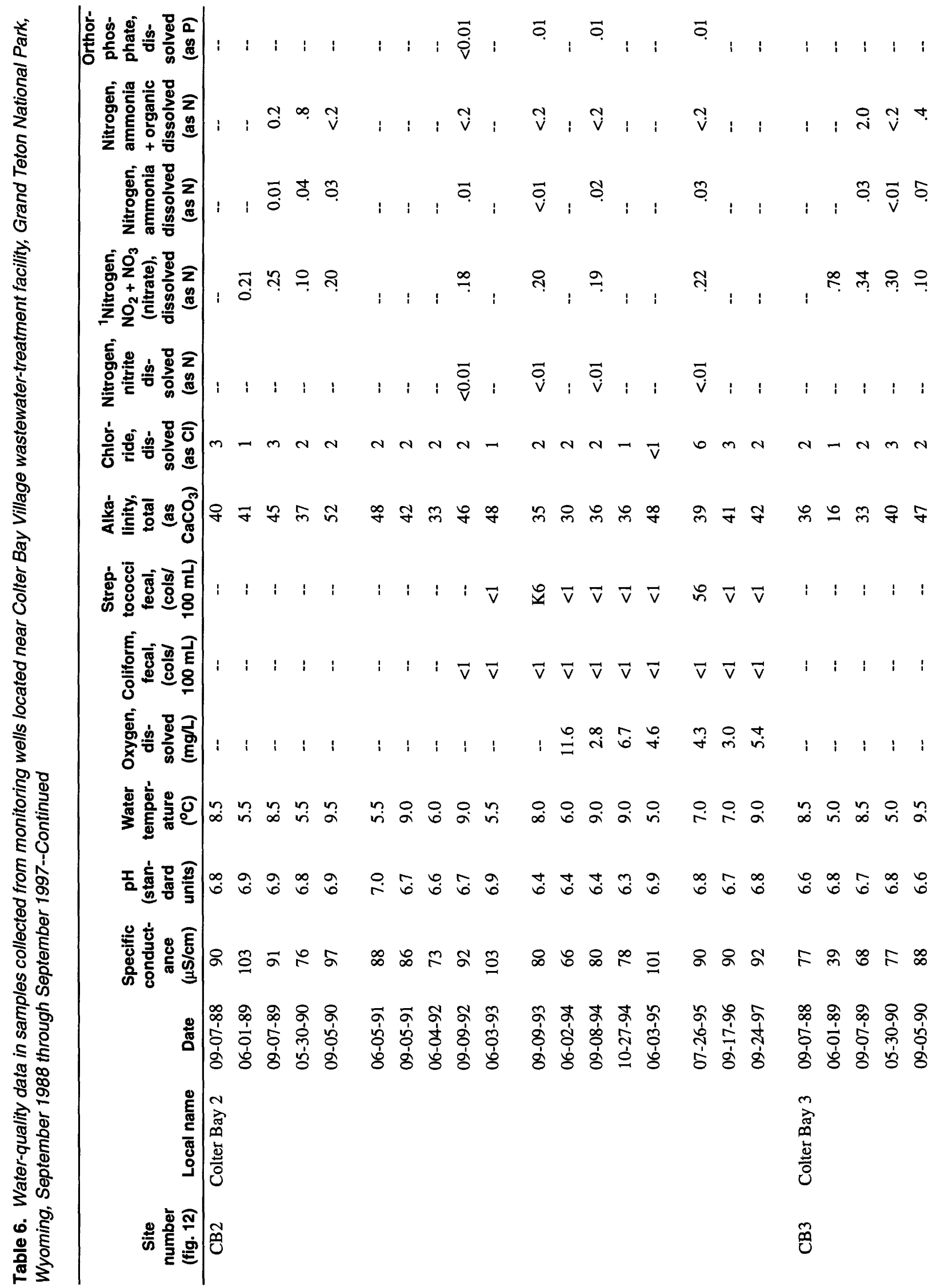




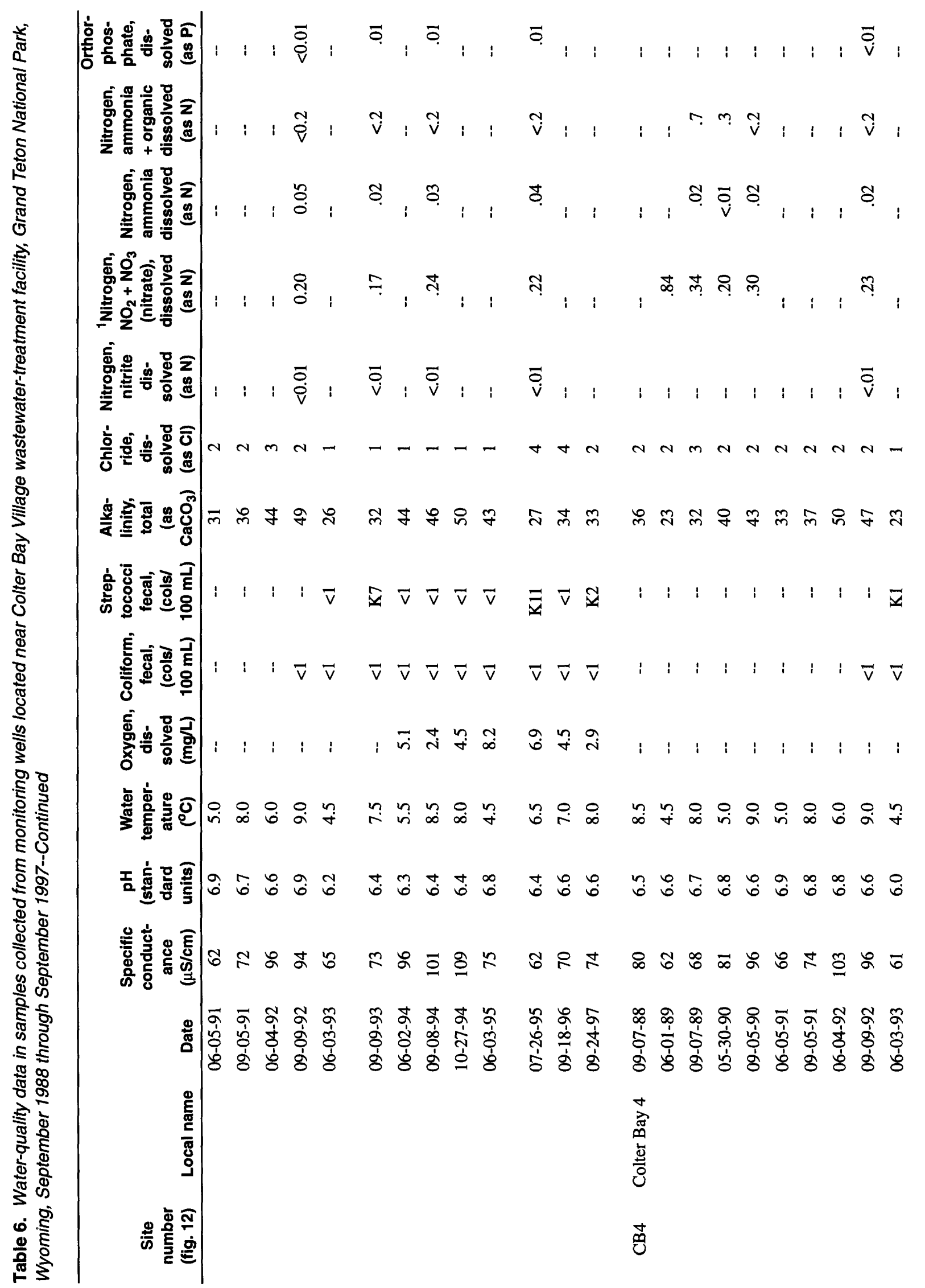




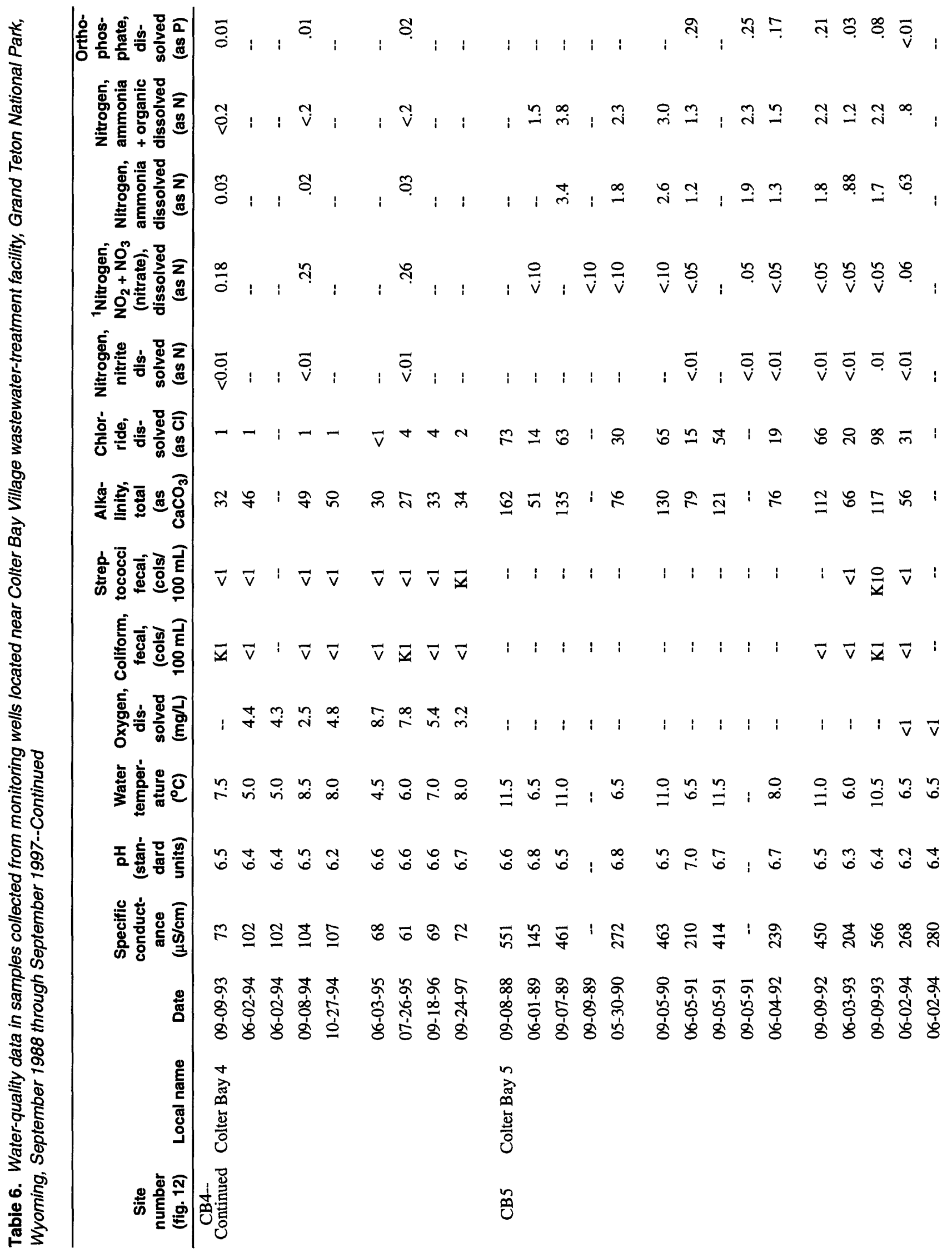




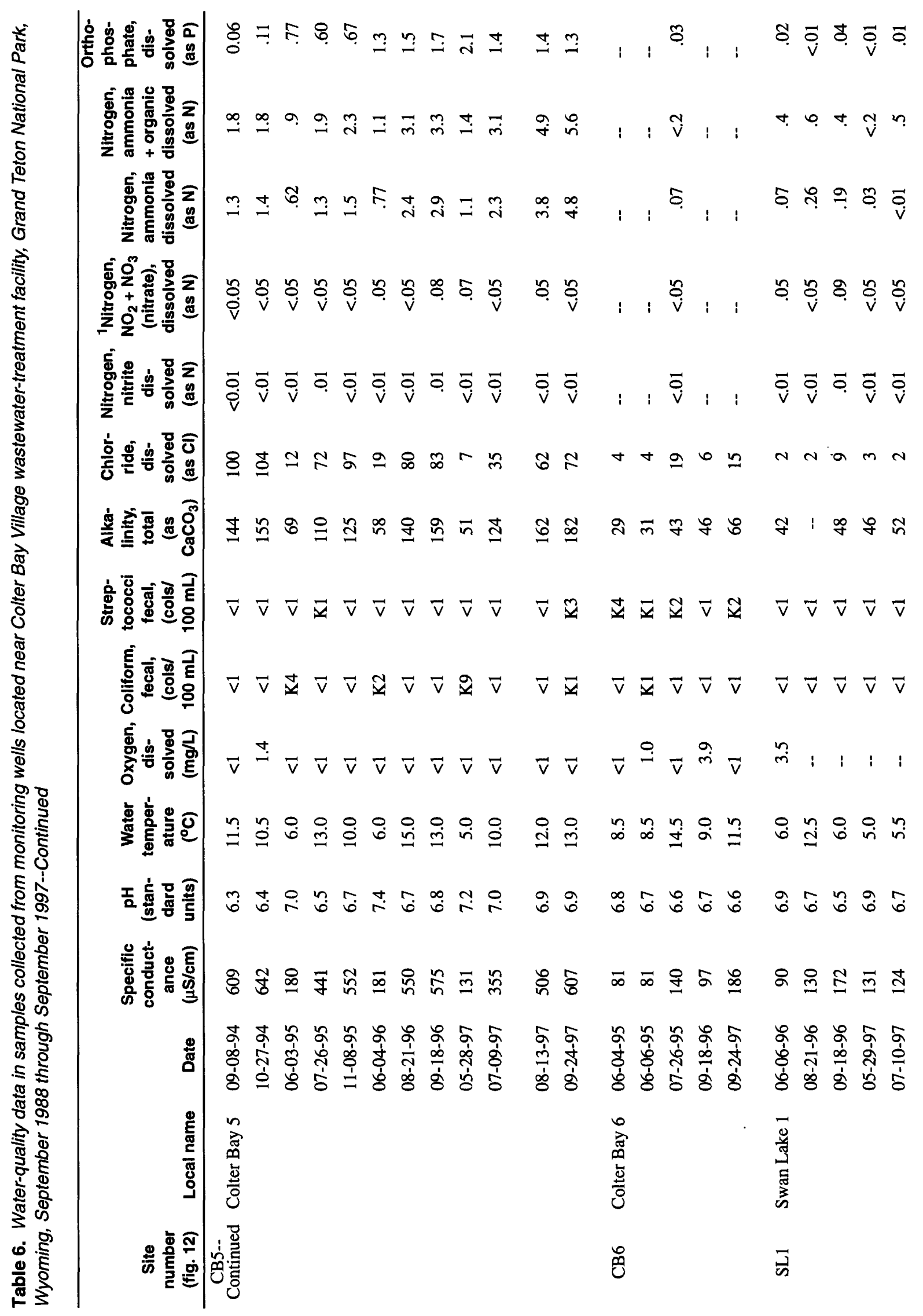




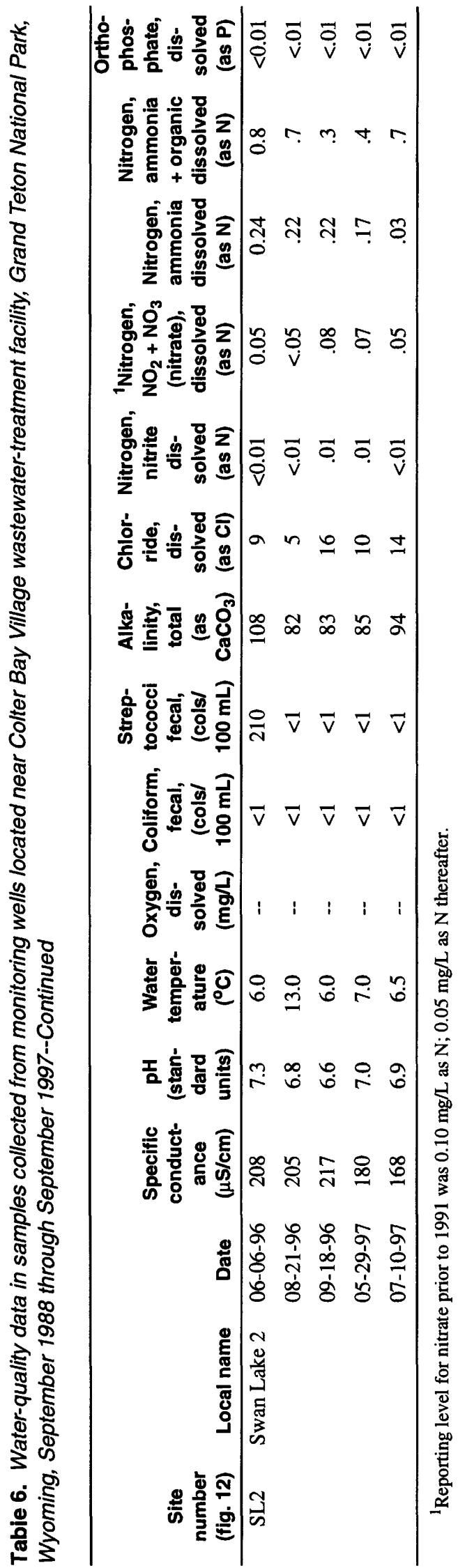



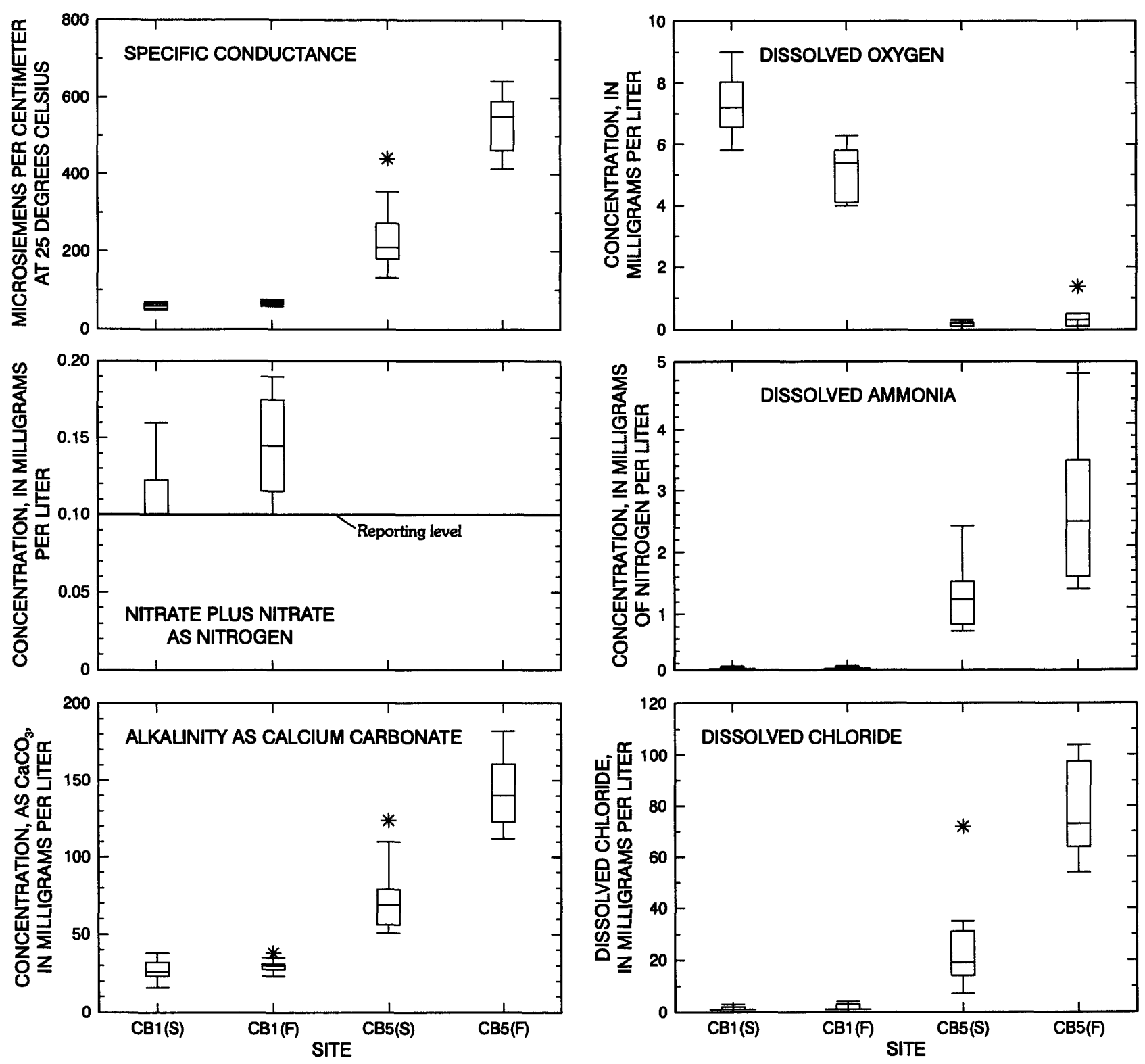

\section{EXPLANATION}

CB1 Monitoring well number-( $\mathrm{F}$, fall samples; (S), spring samples

\section{Constituent}

Outlier data value less than or equal to 3 and more than 1.5 times the interquartile range outside the quartile

Data value less than or equal to 1.5 times the interquartile range outside the quartile

75th percentile

Median

25th percentile

Figure 15. Boxplots showing seasonal variability of selected constituents in samples collected from two monitoring wells located near Colter Bay Village wastewater-treatment facility, 1988-97, Grand Teton National Park, Wyoming (well locations and site numbers are shown in figure 12). 
A noticeable seasonal variation exists for specific conductance, alkalinity, dissolved chloride, and dissolved ammonia in samples collected from CB5 (fig. 15). Specific conductance, alkalinity, dissolved chloride, and dissolved ammonia are higher in the fall than in the spring. A likely explanation for the seasonality of water-quality parameters observed in samples collected from CB5 is that treated wastewater from the facility is impacting the ground water being sampled from this well.

The higher specific conductance and dissolvedchloride and orthophosphate concentrations in samples collected from well CB5 are most likely the result of treated wastewater reaching and mixing with the native ground water near well CB5. The contrasts of concentrations of dissolved oxygen, alkalinity, nitrate, and dissolved ammonia between CB5 and wells CB1, CB2, $\mathrm{CB} 3$, and CB4 are most likely the result of biologically-mediated oxidation-reduction reactions occurring in the ground water. These reactions would be a logical and direct consequence of organic loading to the native ground water caused by the infiltration of the treated wastewater. Oxidation of dissolved-organic matter in the wastewater would initially deplete most or all of the available dissolved oxygen in the ground water. At that point, bacteria would continue to oxidize available organic matter, utilizing oxidized nitrogen (nitrate). This process can result in the reduction of nitrate all the way to ammonia (Drever, 1997). These types of reductive processes seem to be the best available explanation for the decreased concentrations of nitrate and dissolved oxygen (in relation to the other four wells), and increased ammonia concentrations in samples from CB5. Oxidation of organic matter would result in production of carbon dioxide, which would explain the increased alkalinity concentrations in samples collected from well CB5. It appears likely that treated wastewater from the Colter Bay Village facility is significantly impacting the shallow ground water in the vicinity of the facility.

In 1995 and 1997, reconnaissance sampling was conducted along Swan Lake and Third Creek (fig. 12). Data collected during these sampling periods are discussed, but are not listed in table 6 . Water-quality data for the shallow wells (SL1 and SL2) installed along Swan Lake are listed in table 6.

Specific-conductance measurements were made in surface-water samples collected in 1995 along the shoreline of Swan Lake between SL1 and where Third Creek enters Swan Lake (fig. 12). Specific- conductance increased from $120 \mu \mathrm{S} / \mathrm{cm}$ in a sample collected near the northwest part of the lake to $210 \mu \mathrm{S} / \mathrm{cm}$ in a sample collected near the inlet of Third Creek. Specific-conductance measurements and field determinations of dissolved-chloride concentrations were made in surface-water samples collected at two sites in Third Creek during 1997. One sample was collected near the outlet of Cygnet Pond and a second sample was collected near the inlet of Third Creek to Swan Lake. Specific-conductance ranged from $70 \mu \mathrm{S} / \mathrm{cm}$ near the outlet of Cygnet Pond to $167 \mu \mathrm{S} / \mathrm{cm}$ near the inlet to Swan Lake. Dissolved-chloride concentrations ranged from $1 \mathrm{mg} / \mathrm{L}$ near the outlet of Cygnet Pond to $3 \mathrm{mg} / \mathrm{L}$ near the inlet to Swan Lake. One sample collected from well SL1 had a streptococci bacteria concentration of $210 \mathrm{col} / 100 \mathrm{~mL}$. All other samples collected from SL1 and SL2 had concentrations of less than $1 \mathrm{col} / 100 \mathrm{~mL}$. These data are insufficient to determine if discharge from the facility is affecting Swan Lake or Third Creek. Detailed flow-path analysis and additional sampling would be needed.

\section{Modifications to the Existing Monitoring-well Network}

To determine the direction of horizontal and vertical ground-water flow and to better monitor water quality near the Grand Teton wastewater-treatment facility, three clusters of wells (three wells per cluster) installed near the southwestern, southern, and southeastern border of the facility would be useful. Cores or drill cuttings obtained from well installation would allow the geology around the facility to be better described. Wells completed with 5- to 10-ft screened intervals at different depths will allow any vertical component of flow to be measured and water-quality changes with depth to be assessed. The shallowest well of each cluster could be constructed so that the top of the screen would be above the water table. A cluster of wells installed north of the facility could provide samples to help determine background concentrations of selected constituents and help determine if concentrations detected in samples collected from wells at the site are a result of facility operations. Ground-water flow direction near the facility will be better defined by collecting water-level measurements in the newly installed wells. Wells CB1, CB2, CB3, CB4, and CB5 would be available for additional sampling if necessary. Well CB6 can be discontinued, sealed, and abandoned. 
Water-level measurements and water-quality samples collected more frequently would better reflect seasonal water-level changes and help identify any seasonal water-quality component. Once a seasonal component has been identified, samples could be collected less frequently. Samples could be collected in the spring and fall, similar to the present sampling schedule. If water quality appears to be significantly impacted by facility operations, additional samples could be collected. A significant impact might include a continual increase in chemical and (or) biological constituent concentrations (approaching or exceeding MCLs or water-quality recommendations).

\section{Flagg Ranch}

\section{Description of Facilities}

The Flagg Ranch wastewater-treatment facility, constructed in 1978 , is located about $3,000 \mathrm{ft}$ north of Flagg Ranch (fig. 16). Wastewater is pumped from Flagg Ranch to the facility, an aerated lagoon system, which can process 63,000 gallons per day. A lift station at the facility is used to pump wastewater into aeration ponds, where the wastewater undergoes aerobic digestion. New polypropylene liners were installed in the aeration ponds in 1995 in anticipation of new growth at Flagg Ranch. New motel units, a gas station, and a restaurant were constructed in 1993-94, and construction for additional employee housing units began in 1996. A failed liner was replaced during late June and early July 1997. Vegetation in the area is predominately conifers and grasses.

Three monitoring wells (FR3, FR5, and FR6) ranging in depth from 37 to $50 \mathrm{ft}$, are located near the facility. An unused water-supply well (FR4) is located near the facility. Construction records for selected wells are listed in table 11 in Appendix I at the end of report.

\section{Hydrogeology}

Well logs indicate that the monitoring wells are completed in unconsolidated deposits consisting of sand, gravel, and cobbles. Logs for FR5 and FR6 are shown in figure B-4 in Appendix II at the end of the report. The two wells were measured with a steel tape in 1997, and depths measured are shallower than depths shown in the drilling record indicating that sediment has settled in the well casings.
Water-level measurements made in monitoring wells from September 1988 through September 1997 are listed in table 7. Water levels measured September 25,1997 are shown in figure 16. Nolan and Miller's (1995) water-table contour map (fig. 6) does not extend far enough north to include the Flagg Ranch area. A general hydrogeologic section, the depths of monitoring wells, the water level measured September 25, 1997 , and the general lithology at selected monitoring wells located near the facility are shown in figure 17.

\section{Water Quality}

Water-quality samples were collected from the three monitoring wells (FR3, FR5, and FR6) and the unused water-supply well (FR4) (table 8). Samples were collected from well FR3 from September 1988 through September 1997. One sample was collected in September 1997 from each of the other two monitoring wells (FR5 and FR6). Because only one sample was collected from FR5 and FR6, the data represent water quality only at one point in time. Samples were collected from the unused water-supply well FR4 from September 1991 through September 1997. Most of the data were collected prior to the failure of the liner, thus the data are possibly useful for comparison purposes of pre- and post-liner replacement.

Specific-conductance measurements ranged from 239 to $615 \mu \mathrm{S} / \mathrm{cm}$ in samples collected from monitoring wells. Because the depth of the unused water-supply well is unknown, comparisons between FR3 and FR4 are not warranted. Measurements were fairly consistent in samples collected from FR4, ranging from 264 to $296 \mu \mathrm{S} / \mathrm{cm}$. The measurement in the sample collected from FR5 ( $312 \mu \mathrm{S} / \mathrm{cm}$ ) was comparable to measurements in samples collected from FR3; the measurement in the sample from FR6 $(239 \mu \mathrm{S} / \mathrm{cm})$ was lower than any specific-conductance measurements in FR3. The high water temperatures measured in water-supply wells FR1 and FR2 north of the facility (discussed in the water-supply well section later in the report) were not evident in samples collected from the monitoring wells near the treatment facility.

Fecal coliform bacteria concentrations were less than $1 \mathrm{col} / 100 \mathrm{~mL}$ in all samples collected from the monitoring wells and the unused water-supply well. Fecal streptococci bacteria concentrations were less than $1 \mathrm{col} / 100 \mathrm{~mL}$ in 12 of 14 samples collected from monitoring wells. Concentrations were less than 


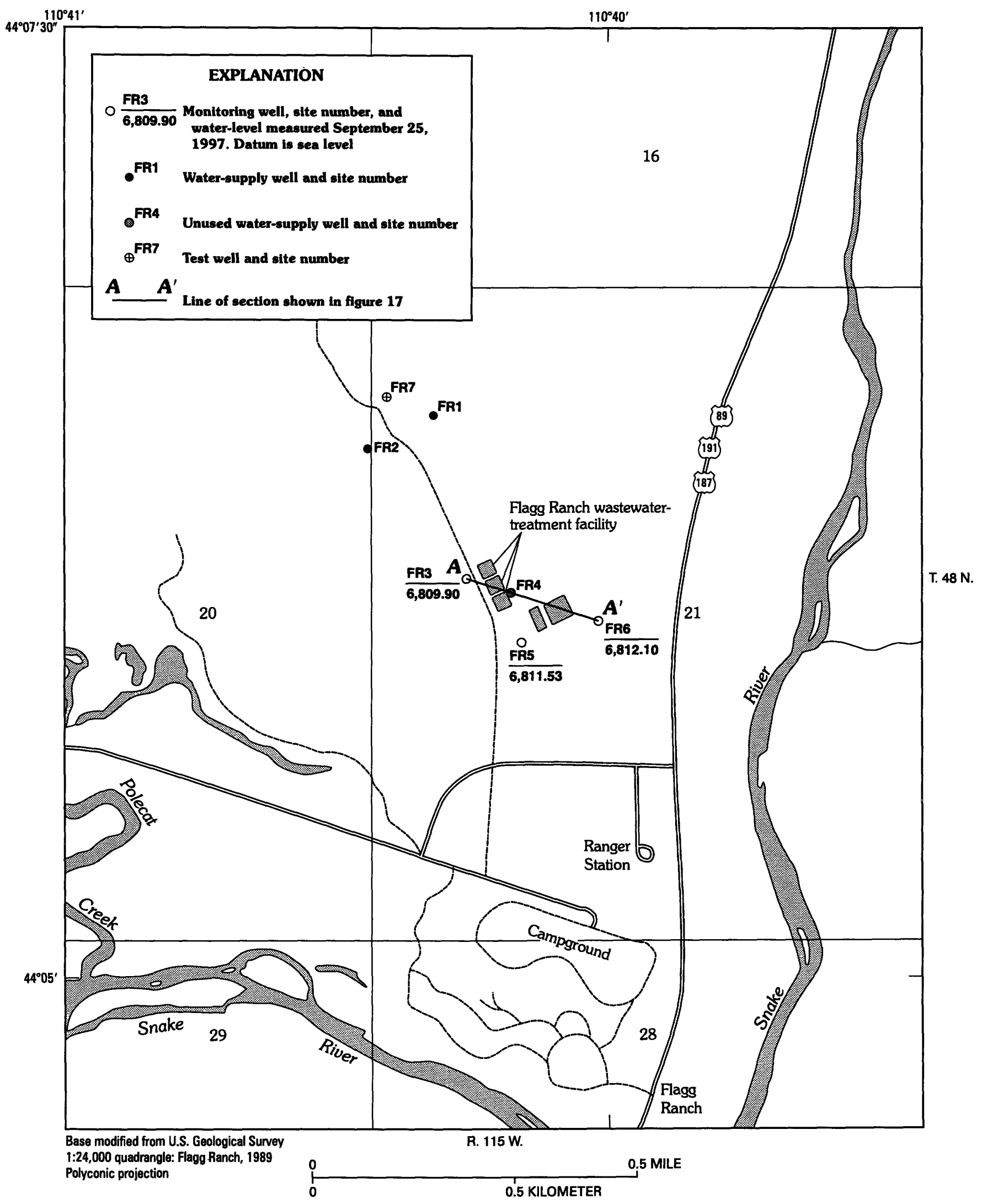

Figure 16. Location of water-supply wells and monitoring wells near Flagg Ranch wastewater-treatment facility, and water-levels measured September 25, 1997, John D. Rockefeller, Jr., Memorial Parkway, Wyoming. 
Table 7. Water-level measurements in monitoring wells and an unused water-supply well located near Flagg Ranch wastewater-treatment facility, John D. Rockefeller, Jr., Memorial Parkway, Wyoming, September 1988 through September 1997

[Local number: See text describing well-numbering system. *, altitude of land surface determined by level line run from benchmarks. Abbreviations: --, data not available]

\begin{tabular}{|c|c|c|c|c|c|c|c|}
\hline $\begin{array}{c}\text { Site } \\
\text { number } \\
\text { (fig. 16) }\end{array}$ & Local number & Local name & $\begin{array}{l}\text { Altitude of } \\
\text { land surface } \\
\text { (feet above } \\
\text { sea level) }\end{array}$ & $\begin{array}{l}\text { Depth of well } \\
\text { (feet below } \\
\text { land surface) }\end{array}$ & $\begin{array}{c}\text { Water level } \\
\text { date }\end{array}$ & $\begin{array}{l}\text { Water level } \\
\text { (feet below } \\
\text { land surface) }\end{array}$ & $\begin{array}{c}\text { Water level } \\
\text { (feet above } \\
\text { sea level) }\end{array}$ \\
\hline \multirow[t]{26}{*}{ FR3 } & $48-115-21 \mathrm{bc0}$ & Flagg Ranch near & $6,834.24$ & 37 & $09-07-88$ & 26.70 & 6807.54 \\
\hline & & Lagoon & & & $09-07-88$ & 27.10 & 6807.14 \\
\hline & & & & & $06-02-89$ & 22.61 & 6811.93 \\
\hline & & & & & 09-08-89 & 25.84 & 6808.40 \\
\hline & & & & & $06-02-90$ & 24.95 & 6809.29 \\
\hline & & & & & $09-05-90$ & 26.50 & 6807.74 \\
\hline & & & & & $06-06-91$ & 23.20 & 6811.04 \\
\hline & & & & & $09-06-91$ & 26.14 & 6808.10 \\
\hline & & & & & $06-05-92$ & 25.74 & 6808.50 \\
\hline & & & & & $09-10-92$ & 27.25 & 6806.99 \\
\hline & & & & & $06-04-93$ & 23.05 & 6811.19 \\
\hline & & & & & $07-13-93$ & 23.88 & 6810.36 \\
\hline & & & & & $09-10-93$ & 25.79 & 6808.45 \\
\hline & & & & & $06-03-94$ & 25.54 & 6808.70 \\
\hline & & & & & $09-09-94$ & 27.10 & 6807.14 \\
\hline & & & & & $10-28-94$ & 27.66 & 6806.58 \\
\hline & & & & & $06-04-95$ & 22.61 & 6811.63 \\
\hline & & & & & $07-27-95$ & 24.03 & 6810.21 \\
\hline & & & & & $11-07-95$ & 26.62 & 6807.62 \\
\hline & & & & & $06-05-96$ & 20.50 & 6813.74 \\
\hline & & & & & $08-22-96$ & 24.10 & 6810.14 \\
\hline & & & & & $09-19-96$ & 24.65 & 6809.59 \\
\hline & & & & & $05-29-97$ & 18.22 & 6816.02 \\
\hline & & & & & $07-08-97$ & 20.57 & 6813.67 \\
\hline & & & & & $08-14-97$ & 22.85 & 6811.39 \\
\hline & & & & & $09-25-97$ & 24.34 & 6809.90 \\
\hline \multirow[t]{18}{*}{ FR4 } & $48-115-21 b c 02$ & Flagg Ranch at & $6,837.06$ & -- & $09-06-91$ & 27.70 & 6809.36 \\
\hline & & Lagoon & & & $06-05-92$ & 27.24 & 6809.82 \\
\hline & & & & & $09-11-92$ & 28.93 & 6808.13 \\
\hline & & & & & $06-04-93$ & 24.32 & 6812.74 \\
\hline & & & & & $09-10-93$ & 27.39 & 6809.67 \\
\hline & & & & & $06-03-94$ & 27.00 & 6810.06 \\
\hline & & & & & 09-09-94 & 28.77 & 6808.29 \\
\hline & & & & & $10-28-94$ & 28.32 & 6808.74 \\
\hline & & & & & $06-04-95$ & 23.83 & 6813.23 \\
\hline & & & & & $07-27-95$ & 25.50 & 6811.56 \\
\hline & & & & & $11-07-95$ & 28.37 & 6808.69 \\
\hline & & & & & $06-05-96$ & 21.78 & 6815.28 \\
\hline & & & & & $08-22-96$ & 25.71 & 6811.35 \\
\hline & & & & & $09-19-96$ & 26.67 & 6810.39 \\
\hline & & & & & $05-29-97$ & 19.83 & 6817.23 \\
\hline & & & & & $07-08-97$ & 22.37 & 6814.69 \\
\hline & & & & & $08-14-97$ & 24.72 & 6812.34 \\
\hline & & & & & $09-25-97$ & 26.24 & 6810.82 \\
\hline FR5 & $48-115-21 b c a 01$ & Flagg Ranch 5 & $6,838.02$ & 50 & $09-25-97$ & 26.49 & 6811.53 \\
\hline FR6 & $48-115-21 b d b 01$ & Flagg Ranch 6 & $6,844.78$ & 50 & $09-25-97$ & 32.68 & 6812.10 \\
\hline
\end{tabular}




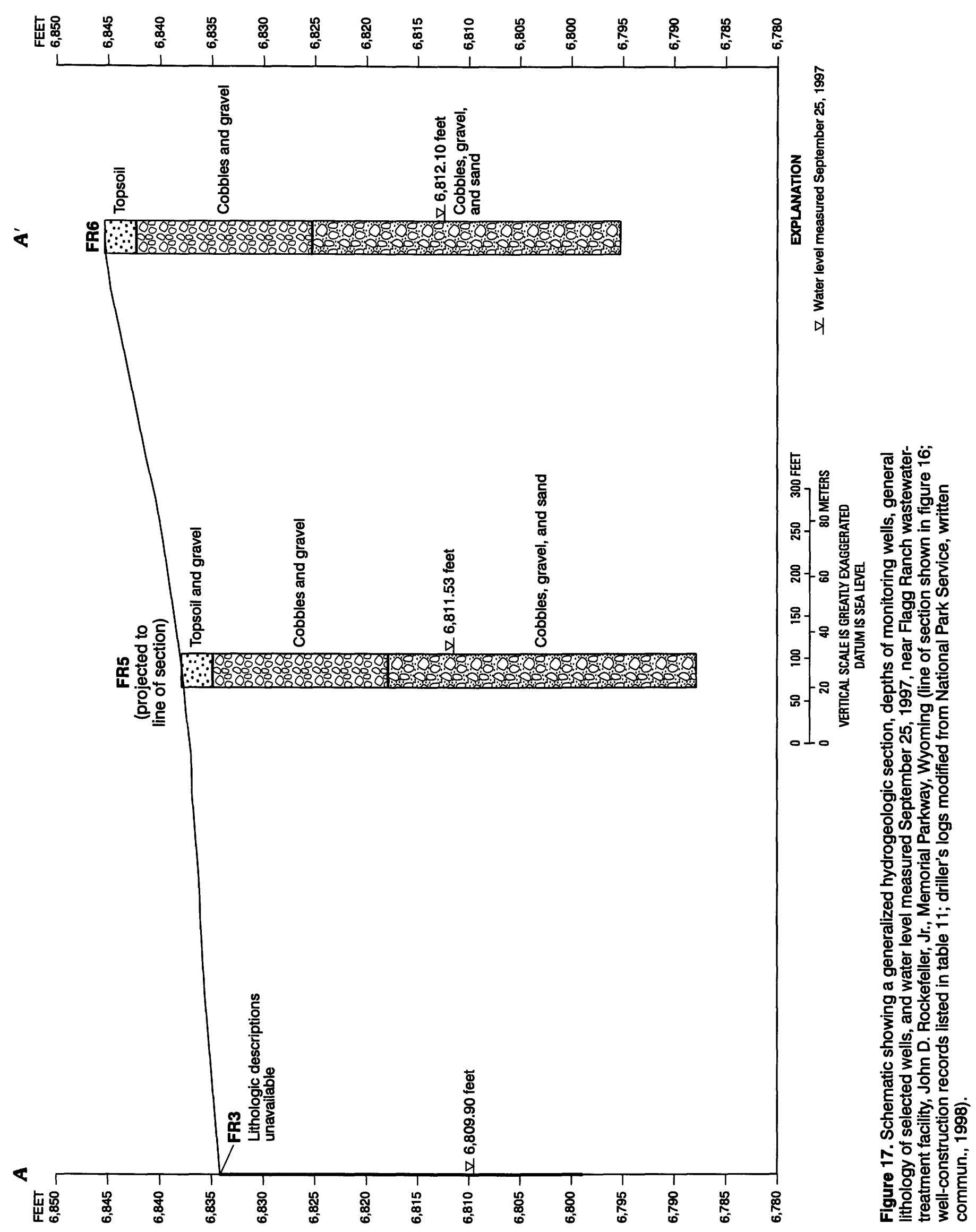




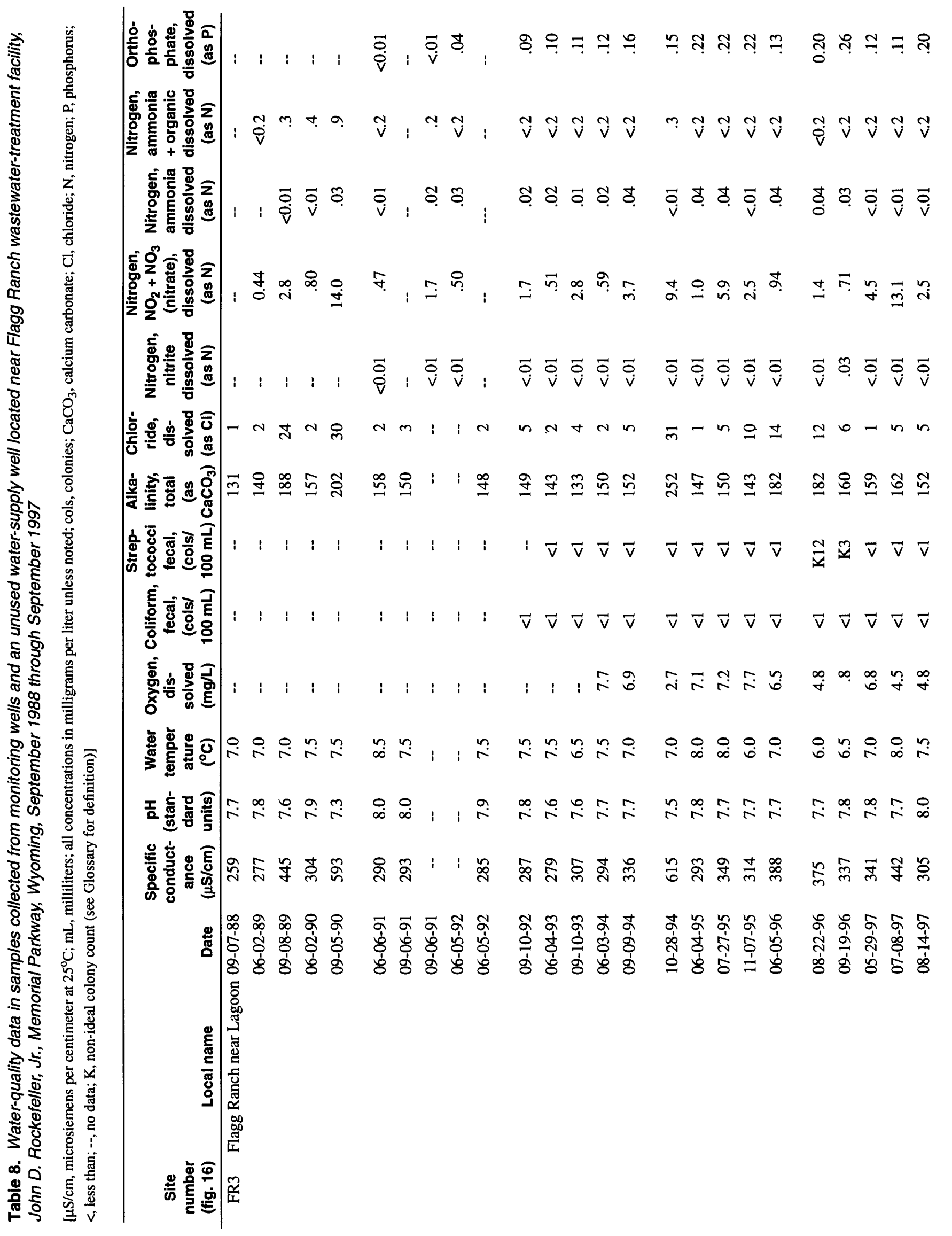




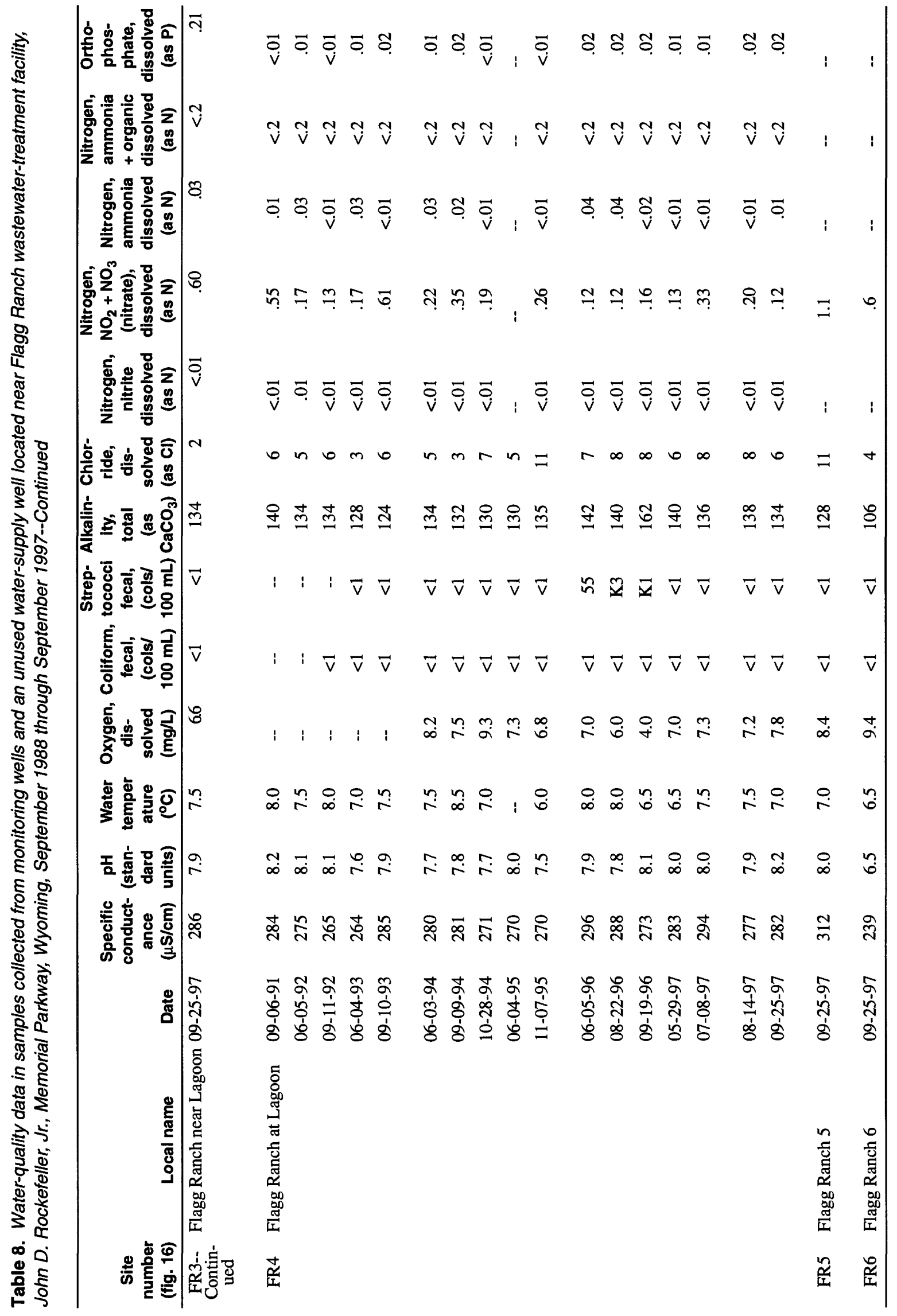


$1 \mathrm{col} / 100 \mathrm{~mL}$ in 12 of 15 samples collected from FR4. All bacteria detections occurred in 1996. All samples collected in 1997 had bacteria concentrations less than $1 \mathrm{col} / 100 \mathrm{~mL}$. As noted earlier in this section, a new liner was replaced in June and July 1997; thus, the possibility exists that the presence of bacteria was a result of the failed liner.

Alkalinity concentrations ranged from 106 to $252 \mathrm{mg} / \mathrm{L}$ in samples collected from the monitoring wells. The two lowest concentrations occurred in the samples collected from FR5 and FR6. Concentrations were fairly consistent in samples from FR4, ranging from 124 to $162 \mathrm{mg} / \mathrm{L}$. Dissolved-chloride concentrations ranged from 1 to $31 \mathrm{mg} / \mathrm{L}$ in samples from the monitoring wells and from 3 to $11 \mathrm{mg} / \mathrm{L}$ in samples from FR4. Samples collected from monitoring wells in 1997 had dissolved-chloride concentrations ranging from 1 to $6 \mathrm{mg} / \mathrm{L}$; an exception was the sample collected in September from FR5, which had a concentration of $11 \mathrm{mg} / \mathrm{L}$.

Nitrate concentrations ranged from 0.44 to $14.0 \mathrm{mg} / \mathrm{L}$ as $\mathrm{N}$ in samples from FR3. Nitrate concentrations, determined in the field, were $1.1 \mathrm{mg} / \mathrm{L}$ as $\mathrm{N}$ in FR5 and $0.6 \mathrm{mg} / \mathrm{L}$ as $\mathrm{N}$ in samples from FR6. A concentration of $14.0 \mathrm{mg} / \mathrm{L}$ as $\mathrm{N}$ occurred in a sample collected from FR3 in September 1990, and a concentration of $13.1 \mathrm{mg} / \mathrm{L}$ as $\mathrm{N}$ occurred in a sample collected from FR3 in July 1997, both of which exceed the MCL of $10 \mathrm{mg} / \mathrm{L}$ established by the U.S. Environmental Protection Agency (1996). Other samples had concentrations ranging from 0.44 to $5.9 \mathrm{mg} / \mathrm{L}$ as $\mathrm{N}$; an exception was a sample collected in October 1994 that had a concentration of $9.4 \mathrm{mg} / \mathrm{L}$ as $\mathrm{N}$. Concentrations ranged from 0.12 to $0.61 \mathrm{mg} / \mathrm{L}$ as $\mathrm{N}$ in samples from the unused water-supply well (FR4). Nitrite concentrations were less than $0.01 \mathrm{mg} / \mathrm{L}$ as $\mathrm{N}$ in 17 of 18 samples from FR3 and in 16 of 17 samples from FR4. Dissolved-ammonia concentrations ranged from less than 1 to $0.04 \mathrm{mg} / \mathrm{L}$ as $\mathrm{N}$ in samples from FR3 and FR4. Dissolved ammonia plus organic concentrations ranged from less than 0.2 to $0.9 \mathrm{mg} / \mathrm{L}$ as $\mathrm{N}$ in samples from FR3 and FR4. Orthophosphate concentrations ranged from less than 0.01 to $0.26 \mathrm{mg} / \mathrm{L}$ in samples collected from FR3; concentrations ranged from less than 0.01 to $0.02 \mathrm{mg} / \mathrm{L}$ in samples collected from FR4.

\section{Modifications to the Existing Monitoring-well Network}

To determine the direction of horizontal and vertical ground-water flow and to better monitor water quality near the Flagg Ranch wastewater-treatment facility, three clusters of wells (three wells per cluster) installed near the eastern, southern, and western borders of the facility would be useful. Wells completed with 5- to 10-ft screened intervals at different depths will allow any vertical component of flow to be measured and water-quality changes with depth to be assessed. The shallowest well of each cluster could be constructed so that the top of the screen would be above the water table. A cluster of wells installed north to northeast of the facility could provide samples to help determine background concentrations of selected constituents in samples and help determine if concentrations in samples collected from wells at the site are the result of facility operations. Ground-water flow direction near the facility will be better defined by waterlevel measurements in the newly installed wells. Wells FR3, FR5, and FR6 would be available for additional sampling if necessary. Wells FR4 and FR7 could be discontinued, sealed, and abandoned.

Water-level measurements and water-quality samples collected more frequently would better reffect seasonal water-level changes and provide any seasonal water-quality component. Once a seasonal component has been identified, samples could be collected less frequently. Samples could be collected in the spring and fall, similar to the present sampling schedule. If water quality appears to be significantly impacted by facility operations, additional samples could be collected. A significant impact might include a continual increase in chemical and (or) biological constituent concentrations (approaching or exceeding MCLs or water-quality recommendations).

\section{WATER-SUPPLY WELLS}

Periodic water-level measurements and waterquality samples were collected in wells that supply potable water to the four wastewater-treatment facilities and in selected water-supply wells not directly associated with wastewater-treatment facilities. The 
Taggert Creek water-supply well (TC1) is located approximately $2.5 \mathrm{mi}$ northwest of the leachfield at Moose Village and provides potable water to Moose Village and Beaver Creek (fig. 8). Water-supply wells (SM6 and SM7) located near the Signal Mountain Marina (fig. 10) are about 1 to 1.2 mi north of the Signal Mountain wastewater-treatment facility. The primary water-supply well, SM6 (fig. 10) is located about $1,200 \mathrm{ft}$ southeast of the lodge and provides potable water to the lodge, campground, boat landing, and employee housing or rental units. Water-supply well SM7 is located near the boat landing and serves as an emergency backup well. Three water-supply wells (PC1, PC2, and PC3), located along Pilgrim Creek east of Colter Bay Village (fig. 1), supply potable water to Jackson Lake Lodge and Colter Bay Village. Two water-supply wells (FR1 and FR2), located about $1 \mathrm{mi}$ north of Flagg Ranch (fig. 16), supply potable water to the Flagg Ranch complex. An additional test well (FR7), about $27 \mathrm{ft}$ deep, is located about $400 \mathrm{ft}$ north of the two water-supply wells, FRl (about $95 \mathrm{ft}$ deep) and FR2 (about $100 \mathrm{ft}$ deep). The locations of selected water-supply wells not directly associated with wastewater-treatment facilities are shown in figure 1. Waterlevel measurements made in the water-supply wells during 1988-97 are listed in table 9. Water-quality data collected from water-supply wells during 1988-97 and the test well (FR7) are listed in table 10. Available well-construction records for selected water-supply wells are listed in table 11 in Appendix I at the end of the report.

Contours, where present on the water-table map for July 1993 (fig. 6), indicate that the water-supply wells are located upgradient of the wastewatertreatment facilities. Water-quality data (table 10) indicate that the water- supply wells are unaffected by wastewater-treatment facility operations. Overall, constituent concentrations are low; thus, only those supply wells that have high concentrations of selected constituents will be discussed in this section.
Water temperatures ranged from about 5.0 to $12.5^{\circ} \mathrm{C}\left(41.0\right.$ to $\left.54.5^{\circ} \mathrm{F}\right)$ (table 10 ), which is a typical range of ground-water temperatures (Todd, 1980). Exceptions occurred in samples collected from wells FR1 and FR2 located north of Flagg Ranch (fig. 16). Temperatures ranged from 15.0 to $18.0^{\circ} \mathrm{C}$ (59 to $\left.64.4^{\circ} \mathrm{F}\right)$ in FR1 and 18.0 to $19.5^{\circ} \mathrm{C}\left(64.4\right.$ to $\left.67.1^{\circ} \mathrm{F}\right)$ in FR2. The higher temperatures probably are a result of geothermal activity in the area. Huckleberry Hot Springs is located about $3,000 \mathrm{ft}$ west of the two watersupply wells.

Specific conductance and dissolved-chloride concentrations also are higher in samples from wells FR1 and FR2 in comparison to other water-supply wells and monitoring wells in the study area. The solute content in thermal ground water is commonly higher than in nonthermal water (Hem, 1985). Specific conductance ranged from 390 to $468 \mu \mathrm{S} / \mathrm{cm}$ in samples collected from FR1 and 470 to $500 \mu \mathrm{S} / \mathrm{cm}$ in samples from FR2 (table 10).

Dissolved-chloride concentrations ranged from 14 to $33 \mathrm{mg} / \mathrm{L}$ in samples collected from FR 1 and from 27 to $40 \mathrm{mg} / \mathrm{L}$ in samples from FR2 (table 10). Chloride is a common constituent in hot springs (Hem, 1985); thus, the higher concentrations might be naturally occurring. Concentrations of dissolved chloride in the other water-supply wells ranged from 1 to $8 \mathrm{mg} / \mathrm{L}$.

Samples for bacteria analysis were collected from four wells-three near Flagg Ranch and one near Jenny Lake. Fecal coliform bacteria concentrations were less than $1 \mathrm{col} / 100 \mathrm{~mL}$ in three wells. The exception was a sample collected from well SJ1 near Jenny Lake (fig. 1; table 10) that had a concentration of $71 \mathrm{col} / 100 \mathrm{~mL}$, and a sample collected from well FR7 (fig. 16; table 10) that had a concentration of $\mathrm{K} 11 \mathrm{col} / 100 \mathrm{~mL}$. Only one sample was collected for bacteria analysis in SJ1, and the source of the bacteria is unknown. Three samples were collected from FR7 for bacteria analysis. Fecal streptococci bacteria concentrations were less than 1 to $100 \mathrm{col} / 100 \mathrm{~mL}$ in the three wells near Flagg Ranch. The source of the bacteria in these wells is unknown. 
Table 9. Water-level measurements in selected water-supply wells in Grand Teton National Park and John D. Rockefeller, Jr., Memorial Parkway, Wyoming, September 1988 through September 1997

[Local number: See text describing well-numbering system. *, altitude of land surface estimated from topographic contours from U.S. Geological Survey Quadrangle series maps (1:24,000 scale); otherwise, altitude of land surface determined by level line run from benchmarks. --, data not available]

\begin{tabular}{|c|c|c|c|c|c|c|c|}
\hline $\begin{array}{c}\text { Site } \\
\text { number }\end{array}$ & Local number & Local name & $\begin{array}{l}\text { Altitude of } \\
\text { land surface } \\
\text { (feet above } \\
\text { sea level) }\end{array}$ & $\begin{array}{c}\text { Depth of well } \\
\text { (feet below } \\
\text { land } \\
\text { surface) }\end{array}$ & $\begin{array}{c}\text { Water level } \\
\text { date }\end{array}$ & $\begin{array}{l}{ }^{1} \text { Water level } \\
\text { (feet below } \\
\text { land surface) }\end{array}$ & $\begin{array}{c}\text { Water level } \\
\text { (feet above } \\
\text { sea level) }\end{array}$ \\
\hline \multicolumn{8}{|c|}{ Moose Village (fig. 8) } \\
\hline \multirow[t]{15}{*}{ TC1 } & 43-116-11adb01 & Taggart Creek & $6,620 *$ & 160 & $06-03-89$ & 38.98 & 6581.02 \\
\hline & & & & & 09-06-89 & 37.71 & 6582.29 \\
\hline & & & & & $09-06-90$ & 42.48 & 6577.52 \\
\hline & & & & & $09-04-91$ & 40.13 & 6579.87 \\
\hline & & & & & $07-22-92$ & 39.33 & 6580.67 \\
\hline & & & & & $09-13-92$ & 50.15 & 6569.85 \\
\hline & & & & & $06-02-93$ & 40.75 & 6579.25 \\
\hline & & & & & $07-12-93$ & 35.92 & 6584.08 \\
\hline & & & & & $09-12-93$ & 37.17 & 6582.83 \\
\hline & & & & & $06-05-94$ & 39.70 & 6580.30 \\
\hline & & & & & $09-11-94$ & 48.84 & 6571.16 \\
\hline & & & & & $07-28-95$ & 5.18 & 6614.82 \\
\hline & & & & & $09-20-96$ & 37.14 & 6582.86 \\
\hline & & & & & $09-25-97$ & 35.11 & 6584.89 \\
\hline & \multicolumn{7}{|c|}{ Signal Mountain (fig. 10) } \\
\hline SM6 & $45-115-25 a b b 01$ & Signal Mountain & $6,945^{*}$ & 301 & $09-12-92$ & 239.56 & 6705.77 \\
\hline & & & & & $06-02-93$ & 260.70 & 6684.30 \\
\hline & & & & & $09-11-93$ & 234.39 & 6710.61 \\
\hline & & & & & $09-11-94$ & 233.72 & 6711.28 \\
\hline \multirow[t]{10}{*}{ SM7 } & $45-115-25 \mathrm{bca} 01$ & Signal Mountain & $6,780 *$ & 206 & $06-04-92$ & 15.25 & 6764.75 \\
\hline & & Marina & & & $06-02-93$ & 36.57 & 6743.43 \\
\hline & & & & & $09-11-93$ & 19.10 & 6760.90 \\
\hline & & & & & $06-04-94$ & 14.56 & 6765.44 \\
\hline & & & & & $09-11-94$ & 28.42 & 6751.58 \\
\hline & & & & & $06-05-95$ & 22.54 & 6757.46 \\
\hline & & & & & $07-28-95$ & 11.42 & 6768.58 \\
\hline & & & & & $09-20-96$ & 18.48 & 6761.52 \\
\hline & & & & & $09-27-97$ & 17.88 & 6762.12 \\
\hline & \multicolumn{7}{|c|}{ Colter Bay (fig. 12) } \\
\hline \multirow[t]{15}{*}{ PC1 } & $46-114-29-\mathrm{db} 01$ & Pilgrim Creek 1 & $6,981.50$ & 200 & $06-02-89$ & 13.83 & 6967.67 \\
\hline & & & & & 09-07-89 & 29.91 & 6951.59 \\
\hline & & & & & $06-01-90$ & 21.00 & 6960.50 \\
\hline & & & & & $09-06-90$ & 46.01 & 6935.49 \\
\hline & & & & & $06-05-90$ & 15.77 & 6965.73 \\
\hline & & & & & $09-05-91$ & 42.42 & 6939.08 \\
\hline & & & & & $06-04-92$ & 39.30 & 6942.20 \\
\hline & & & & & $09-12-92$ & 55.36 & 6926.14 \\
\hline & & & & & $06-04-93$ & 15.33 & 6966.17 \\
\hline & & & & & $07-14-93$ & 21.33 & 6960.17 \\
\hline & & & & & $09-11-93$ & 42.53 & 6938.97 \\
\hline & & & & & $06-04-94$ & 32.99 & 6948.51 \\
\hline & & & & & $09-01-94$ & 56.77 & 6924.73 \\
\hline & & & & & $06-06-95$ & 32.99 & 6948.51 \\
\hline & & & & & $07-28-95$ & 20.21 & 6961.29 \\
\hline
\end{tabular}


Tabie 9. Water-level measurements in selected water-supply wells in Grand Teton National Park and John D. Rockefeller, Jr., Memorial Parkway, Wyoming, September 1988 through September 1997--Continued

\begin{tabular}{|c|c|c|c|c|c|c|c|}
\hline $\begin{array}{c}\text { Site } \\
\text { number }\end{array}$ & Local number & Local name & $\begin{array}{l}\text { Altitude of } \\
\text { land surface } \\
\text { (feet above } \\
\text { sea level) }\end{array}$ & $\begin{array}{c}\text { Depth of well } \\
\text { (feet below } \\
\text { land } \\
\text { surface) }\end{array}$ & $\begin{array}{c}\text { Water level } \\
\text { date }\end{array}$ & $\begin{array}{l}{ }^{1} \text { Water level } \\
\text { (feet below } \\
\text { land surface) }\end{array}$ & $\begin{array}{c}\text { Water level } \\
\text { (feet above } \\
\text { sea level) }\end{array}$ \\
\hline & & & & & $09-23-96$ & 35.64 & 6945.86 \\
\hline & & & & & $09-27-97$ & 44.30 & 6937.20 \\
\hline \multirow[t]{16}{*}{ PC2 } & $46-114-31 \mathrm{ca} 01$ & Pilgrim Creek 2 & $6,884 *$ & 175 & $06-02-89$ & 3.98 & 6880.02 \\
\hline & & & & & 09-07-89 & 27.30 & 6856.70 \\
\hline & & & & & $06-01-90$ & 15.08 & 6868.92 \\
\hline & & & & & $09-06-90$ & 28.84 & 6855.16 \\
\hline & & & & & $06-05-91$ & 17.65 & 6866.35 \\
\hline & & & & & $09-05-91$ & 24.97 & 6859.03 \\
\hline & & & & & $06-04-92$ & 26.40 & 6857.60 \\
\hline & & & & & $09-12-92$ & 39.57 & 6844.43 \\
\hline & & & & & $06-04-93$ & 8.75 & 6875.25 \\
\hline & & & & & $07-14-93$ & 11.15 & 6872.85 \\
\hline & & & & & $06-04-94$ & 20.25 & 6863.75 \\
\hline & & & & & $09-12-94$ & 36.03 & 6847.97 \\
\hline & & & & & $07-14-95$ & 6.51 & 6877.49 \\
\hline & & & & & $07-28-95$ & 10.51 & 6873.49 \\
\hline & & & & & $09-23-96$ & 25.53 & 6858.47 \\
\hline & & & & & $09-27-97$ & 26.36 & 6857.64 \\
\hline \multirow[t]{7}{*}{ PC3 } & $46-114-29 \mathrm{db} 02$ & Pilgrim Creek 3 & $6,976.80$ & 250 & $06-02-89$ & 26.61 & 6950.19 \\
\hline & & & & & $06-02-89$ & 19.72 & 6957.08 \\
\hline & & & & & $09-07-89$ & 37.89 & 6938.91 \\
\hline & & & & & $06-01-90$ & 30.64 & 6946.16 \\
\hline & & & & & $06-04-92$ & 48.47 & 6928.33 \\
\hline & & & & & $06-04-93$ & 22.90 & 6953.90 \\
\hline & & Fla & nch (fig. 16) & & & & \\
\hline \multirow[t]{18}{*}{ FR1 } & $48-115-21 b b 01$ & Flagg Ranch & $6,846 *$ & -- & $06-02-89$ & 6.81 & 6839.19 \\
\hline & & production 1 & & & $09-08-89$ & 8.11 & 6837.89 \\
\hline & & & & & $09-06-90$ & 9.20 & 6836.80 \\
\hline & & & & & $06-06-91$ & 7.80 & 6838.20 \\
\hline & & & & & $09-06-91$ & 9.09 & 6836.91 \\
\hline & & & & & $06-05-92$ & 13.50 & 6832.50 \\
\hline & & & & & $09-11-92$ & 12.63 & 6833.37 \\
\hline & & & & & $06-04-93$ & 8.09 & 6837.91 \\
\hline & & & & & $09-10-93$ & 8.36 & 6837.64 \\
\hline & & & & & $06-03-94$ & 12.14 & 6833.86 \\
\hline & & & & & 09-09-94 & 11.76 & 6834.24 \\
\hline & & & & & $06-04-95$ & 7.06 & 6838.94 \\
\hline & & & & & $07-27-95$ & 7.47 & 6838.53 \\
\hline & & & & & $11-07-95$ & 9.49 & 6836.51 \\
\hline & & & & & $06-05-96$ & 2.43 & 6843.57 \\
\hline & & & & & $05-29-97$ & -.98 & 6846.98 \\
\hline & & & & & $07-08-97$ & .18 & 6845.82 \\
\hline & & & & & $09-26-97$ & 5.49 & 6840.51 \\
\hline \multirow[t]{5}{*}{ FR2 } & $48-115-21 b b 02$ & Flagg Ranch & $6,836 *$ & -- & $06-02-89$ & 3.28 & 6832.72 \\
\hline & & production 2 & & & 09-08-89 & 4.93 & 6831.07 \\
\hline & & & & & $06-02-90$ & 6.61 & 6829.39 \\
\hline & & & & & $09-06-90$ & 6.84 & 6829.16 \\
\hline & & & & & $06-06-91$ & 4.63 & 6831.37 \\
\hline
\end{tabular}


Table 9. Water-level measurements in selected water-supply wells in Grand Teton National Park and John D. Rockefeller, Jr., Memorial Parkway, Wyoming, September 1988 through September 1997--Continued

\begin{tabular}{|c|c|c|c|c|c|c|c|}
\hline $\begin{array}{c}\text { Site } \\
\text { number }\end{array}$ & Local number & Local name & $\begin{array}{l}\text { Altitude of } \\
\text { land surface } \\
\text { (feet above } \\
\text { sea level) }\end{array}$ & $\begin{array}{l}\text { Depth of well } \\
\text { (feet below } \\
\text { land } \\
\text { surface) }\end{array}$ & $\begin{array}{c}\text { Water level } \\
\text { date }\end{array}$ & $\begin{array}{l}{ }^{1} \text { Water level } \\
\text { (feet below } \\
\text { land surface) }\end{array}$ & $\begin{array}{c}\text { Water level } \\
\text { (feet above } \\
\text { sea level) }\end{array}$ \\
\hline FR2-- & & & & & $09-06-91$ & 5.72 & 6830.28 \\
\hline \multirow[t]{14}{*}{ Continued } & & & & & $06-05-92$ & 8.27 & 6827.73 \\
\hline & & & & & $09-11-92$ & 9.20 & 6826.80 \\
\hline & & & & & $06-04-93$ & 4.85 & 6831.15 \\
\hline & & & & & $07-13-93$ & 4.18 & 6831.82 \\
\hline & & & & & $09-10-93$ & 5.14 & 6830.86 \\
\hline & & & & & $09-09-94$ & 8.15 & 6827.85 \\
\hline & & & & & $06-04-95$ & 3.67 & 6832.33 \\
\hline & & & & & $11-07-95$ & 6.61 & 6829.39 \\
\hline & & & & & $06-05-96$ & -.08 & 6836.08 \\
\hline & & & & & $08-22-96$ & 3.02 & 6832.98 \\
\hline & & & & & $09-19-96$ & 4.13 & 6831.87 \\
\hline & & & & & $05-29-97$ & -2.85 & 6838.85 \\
\hline & & & & & $08-13-97$ & 1.50 & 6834.50 \\
\hline & & & & & $09-26-97$ & 3.32 & 6832.68 \\
\hline \multirow[t]{24}{*}{${ }^{2} \mathrm{FR} 7$} & $48-115-16 \mathrm{cc} 01$ & Upper test well & $6,859 *$ & 27 & $06-02-89$ & 21.50 & 6837.50 \\
\hline & & & & & 09-08-89 & 22.58 & 6836.42 \\
\hline & & & & & $06-02-90$ & 24.13 & 6834.87 \\
\hline & & & & & $09-05-90$ & 24.06 & 6834.94 \\
\hline & & & & & $06-06-91$ & 22.58 & 6836.42 \\
\hline & & & & & 09-06-91 & 23.41 & 6835.59 \\
\hline & & & & & $06-05-92$ & 26.00 & 6833.00 \\
\hline & & & & & $09-10-92$ & dry & dry \\
\hline & & & & & $06-04-93$ & 22.35 & 6836.65 \\
\hline & & & & & $07-13-93$ & 21.55 & 6837.45 \\
\hline & & & & & $09-10-93$ & 22.74 & 6836.26 \\
\hline & & & & & $06-03-94$ & 25.38 & 6833.62 \\
\hline & & & & & 09-09-94 & dry & dry \\
\hline & & & & & $10-28-94$ & dry & dry \\
\hline & & & & & 06-04-95 & 22.52 & 6836.48 \\
\hline & & & & & $07-27-95$ & 21.61 & 6837.39 \\
\hline & & & & & $11-07-95$ & 23.78 & 6835.22 \\
\hline & & & & & $06-05-96$ & 17.44 & 6841.56 \\
\hline & & & & & $08-22-96$ & 19.92 & 6839.08 \\
\hline & & & & & $09-19-96$ & 20.94 & 6838.06 \\
\hline & & & & & $05-29-97$ & 14.15 & 6844.85 \\
\hline & & & & & $07-08-97$ & 15.62 & 6843.38 \\
\hline & & & & & $08-13-97$ & 17.95 & 6841.05 \\
\hline & Water-su & ly wells not directly & iated with waste & water-treatmen & facilities & & \\
\hline \multirow[t]{9}{*}{ HL1 } & 43-116-11adb01 & Highlands & $6,685 *$ & 151 & $07-23-92$ & 38.14 & 6646.86 \\
\hline & & & & & $09-12-93$ & 37.33 & 6647.67 \\
\hline & & & & & 06-04-94 & 25.76 & 6659.24 \\
\hline & & & & & $09-11-94$ & 58.54 & 6626.46 \\
\hline & & & & & $06-05-95$ & 34.92 & 6650.08 \\
\hline & & & & & $07-13-95$ & 5.87 & 6679.13 \\
\hline & & & & & $07-28-95$ & 9.87 & 6675.13 \\
\hline & & & & & $09-20-96$ & 46.60 & 6638.40 \\
\hline & & & & & $09-27-97$ & 40.42 & 6642.58 \\
\hline
\end{tabular}


Table 9. Water-level measurements in selected water-supply wells in Grand Teton National Park and John D. Rockefeller, Jr., Memorial Parkway, Wyoming, September 1988 through September 1997--Continued

\begin{tabular}{|c|c|c|c|c|c|c|c|}
\hline $\begin{array}{c}\text { Site } \\
\text { number }\end{array}$ & Local number & Local name & $\begin{array}{c}\text { Altitude of } \\
\text { land surface } \\
\text { (feet above } \\
\text { sea level) }\end{array}$ & $\begin{array}{c}\text { Depth of well } \\
\text { (feet below } \\
\text { land } \\
\text { surface) }\end{array}$ & $\begin{array}{c}\text { Water level } \\
\text { date }\end{array}$ & $\begin{array}{l}\text { 'Water level } \\
\text { (feet below } \\
\text { land surface) }\end{array}$ & $\begin{array}{c}\text { Water level } \\
\text { (feet above } \\
\text { sea level) }\end{array}$ \\
\hline \multirow[t]{9}{*}{ CR1 } & $43-116-11 \mathrm{dbc} 01$ & Climbers Ranch & $6,660 *$ & 88 & $07-21-92$ & 30.13 & 6629.87 \\
\hline & & & & & $07-12-93$ & 11.56 & 6648.44 \\
\hline & & & & & $09-12-93$ & 29.80 & 6630.20 \\
\hline & & & & & 06-04-94 & 20.46 & 6639.54 \\
\hline & & & & & $09-11-94$ & 48.78 & 6611.22 \\
\hline & & & & & $06-05-95$ & 28.25 & 6631.75 \\
\hline & & & & & $07-28-95$ & 7.85 & 6652.15 \\
\hline & & & & & $09-20-96$ & 34.79 & 6625.21 \\
\hline & & & & & $09-27-97$ & 32.00 & 6628.00 \\
\hline \multirow[t]{12}{*}{ JL1 } & 44-116-13abd01 & Jenny Lake Lodge & $6,900 *$ & -- & 09-09-89 & 222.35 & 6677.65 \\
\hline & & & & & $06-01-90$ & 218.10 & 6681.90 \\
\hline & & & & & $09-06-90$ & 209.84 & 6690.16 \\
\hline & & & & & 06-04-91 & 221.69 & 6678.31 \\
\hline & & & & & 09-04-91 & 210.79 & 6689.21 \\
\hline & & & & & $06-04-92$ & 217.44 & 6682.56 \\
\hline & & & & & $09-13-92$ & 219.25 & 6680.75 \\
\hline & & & & & $06-02-93$ & 240.93 & 6659.07 \\
\hline & & & & & $07-12-93$ & 233.91 & 6666.09 \\
\hline & & & & & $09-12-93$ & 218.21 & 6681.79 \\
\hline & & & & & $06-04-94$ & 218.58 & 6681.42 \\
\hline & & & & & $07-28-95$ & 221.19 & 6678.81 \\
\hline \multirow[t]{18}{*}{ SJ1 } & 44-116-26daa01 & South Jenny Lake & $6,795 *$ & 250 & $09-06-89$ & 107.58 & 6687.42 \\
\hline & & & & & $06-02-90$ & 133.25 & 6661.75 \\
\hline & & & & & $09-06-90$ & 122.33 & 6672.67 \\
\hline & & & & & $06-04-91$ & 119.05 & 6675.95 \\
\hline & & & & & 09-04-91 & 115.45 & 6679.55 \\
\hline & & & & & $06-03-92$ & 107.48 & 6687.52 \\
\hline & & & & & $06-03-92$ & 107.25 & 6687.75 \\
\hline & & & & & $07-23-92$ & 112.40 & 6682.60 \\
\hline & & & & & $09-13-92$ & 130.67 & 6664.33 \\
\hline & & & & & $06-02-93$ & 100.52 & 6694.48 \\
\hline & & & & & $07-12-93$ & 81.87 & 6713.13 \\
\hline & & & & & $09-11-93$ & 104.99 & 6690.01 \\
\hline & & & & & $06-04-94$ & 107.40 & 6687.60 \\
\hline & & & & & $09-11-94$ & 130.30 & 6664.70 \\
\hline & & & & & $06-05-95$ & 119.28 & 6675.72 \\
\hline & & & & & $07-28-95$ & 79.63 & 6615.37 \\
\hline & & & & & $09-20-96$ & 111.97 & 6683.03 \\
\hline & & & & & $09-27-97$ & 109.49 & 6685.51 \\
\hline \multirow[t]{10}{*}{ LM1 } & 44-116-26ddd01 & Lupine Meadows & $6,770 *$ & 150 & $07-21-92$ & 46.31 & 6723.69 \\
\hline & & & & & $06-02-93$ & 52.20 & 6717.80 \\
\hline & & & & & $07-12-93$ & 26.97 & 6743.03 \\
\hline & & & & & $09-11-93$ & 67.75 & 6702.25 \\
\hline & & & & & $06-04-94$ & 67.52 & 6707.48 \\
\hline & & & & & $09-11-94$ & 93.09 & 6676.91 \\
\hline & & & & & $06-05-95$ & 77.03 & 6692.97 \\
\hline & & & & & $07-28-95$ & 35.24 & 6734.76 \\
\hline & & & & & $09-20-96$ & 77.16 & 6692.84 \\
\hline & & & & & $09-27-97$ & 75.43 & 6694.57 \\
\hline
\end{tabular}


Table 9. Water-level measurements in selected water-supply wells in Grand Teton National Park and John D. Rockefeller, Jr., Memorial Parkway, Wyoming, September 1988 through September 1997--Continued

\begin{tabular}{|c|c|c|c|c|c|c|c|}
\hline $\begin{array}{c}\text { Site } \\
\text { number }\end{array}$ & Local number & Local name & $\begin{array}{l}\text { Altitude of } \\
\text { land surface } \\
\text { (feet above } \\
\text { sea level) }\end{array}$ & $\begin{array}{l}\text { Depth of well } \\
\text { (feet below } \\
\text { land } \\
\text { surface) }\end{array}$ & $\begin{array}{c}\text { Water level } \\
\text { date }\end{array}$ & $\begin{array}{l}\text { 'Water level } \\
\text { (feet below } \\
\text { land surface) }\end{array}$ & $\begin{array}{c}\text { Water level } \\
\text { (feet above } \\
\text { sea level) }\end{array}$ \\
\hline \multirow[t]{9}{*}{ JD1 } & 45-114-19abb01 & Jackson Lake Dam & $6,810 *$ & 216 & $07-24-92$ & 73.56 & 6736.44 \\
\hline & & & & & $07-12-93$ & 66.43 & 6743.57 \\
\hline & & & & & $06-04-94$ & 68.39 & 6741.61 \\
\hline & & & & & $09-12-94$ & 76.17 & 6733.83 \\
\hline & & & & & $06-05-95$ & 69.75 & 6740.25 \\
\hline & & & & & $07-14-95$ & 67.86 & 6742.14 \\
\hline & & & & & $07-28-95$ & 68.30 & 6741.70 \\
\hline & & & & & $09-20-96$ & 70.22 & 6739.78 \\
\hline & & & & & $09-27-97$ & 67.01 & 6742.99 \\
\hline \multirow[t]{18}{*}{ MJ1 } & $45-114-23 \mathrm{ccd} 01$ & Moran Junction & $6,730 *$ & 55 & $06-03-89$ & 16.95 & 6713.05 \\
\hline & & & & & $09-09-89$ & 11.30 & 6718.70 \\
\hline & & & & & $06-01-90$ & 11.27 & 6718.73 \\
\hline & & & & & $09-07-90$ & 10.93 & 6719.07 \\
\hline & & & & & $06-05-91$ & 9.21 & 6720.79 \\
\hline & & & & & $09-05-91$ & 11.36 & 6718.64 \\
\hline & & & & & $06-05-92$ & 10.02 & 6719.98 \\
\hline & & & & & $09-12-92$ & 11.36 & 6718.64 \\
\hline & & & & & $06-03-93$ & 10.77 & 6719.23 \\
\hline & & & & & $07-13-93$ & 12.5 & 6717.50 \\
\hline & & & & & $09-12-93$ & 11.05 & 6718.95 \\
\hline & & & & & $06-04-94$ & 10.07 & 6719.93 \\
\hline & & & & & $09-12-94$ & 11.13 & 6718.87 \\
\hline & & & & & $06-05-95$ & 8.70 & 6721.30 \\
\hline & & & & & $07-15-95$ & 15.48 & 6714.52 \\
\hline & & & & & $07-28-95$ & 10.52 & 6719.48 \\
\hline & & & & & $09-20-96$ & 10.46 & 6719.54 \\
\hline & & & & & $09-26-97$ & 9.68 & 6720.32 \\
\hline \multirow[t]{17}{*}{ LE1 } & $46-115-23 \operatorname{ccc} 01$ & Leeks Marina & $6,840 *$ & 130 & $06-02-89$ & 71.09 & 6768.91 \\
\hline & & & & & $09-08-89$ & 67.94 & 6772.06 \\
\hline & & & & & $06-01-90$ & 63.30 & 6776.70 \\
\hline & & & & & $09-06-90$ & 66.98 & 6773.02 \\
\hline & & & & & $06-05-91$ & 62.75 & 6777.25 \\
\hline & & & & & $09-05-91$ & 65.73 & 6774.27 \\
\hline & & & & & $06-05-92$ & 62.69 & 6777.31 \\
\hline & & & & & $09-11-92$ & 85.61 & 6754.39 \\
\hline & & & & & $06-03-93$ & 69.67 & 6770.33 \\
\hline & & & & & $07-14-93$ & 67.82 & 6772.18 \\
\hline & & & & & $09-12-93$ & 66.57 & 6773.43 \\
\hline & & & & & $06-04-94$ & 61.89 & 6778.11 \\
\hline & & & & & $09-10-94$ & 77.05 & 6762.95 \\
\hline & & & & & $06-06-95$ & 64.00 & 6776.00 \\
\hline & & & & & $07-28-95$ & 61.38 & 6778.62 \\
\hline & & & & & $09-23-96$ & 67.17 & 6772.83 \\
\hline & & & & & $09-26-97$ & 65.68 & 6774.32 \\
\hline
\end{tabular}


Table 9. Water-level measurements in selected water-supply wells in Grand Teton National Park and John D. Rockefeller, Jr., Memorial Parkway, Wyoming, September 1988 through September 1997--Continued

\begin{tabular}{|c|c|c|c|c|c|c|c|}
\hline $\begin{array}{c}\text { Site } \\
\text { number }\end{array}$ & Local number & Local name & $\begin{array}{c}\text { Altitude of } \\
\text { land surface } \\
\text { (feet above } \\
\text { sea level) }\end{array}$ & $\begin{array}{l}\text { Depth of well } \\
\text { (feet below } \\
\text { land } \\
\text { surface) }\end{array}$ & $\begin{array}{c}\text { Water level } \\
\text { date }\end{array}$ & $\begin{array}{l}\text { 'Water level } \\
\text { (feet below } \\
\text { land surface) }\end{array}$ & $\begin{array}{c}\text { Water leve } \\
\text { (feet above } \\
\text { sea level) }\end{array}$ \\
\hline \multirow[t]{6}{*}{ LC1 } & 47-115-32ab01 & Lizard Creek & $6,810 *$ & 101 & $06-03-94$ & 21.10 & 6788.90 \\
\hline & & & & & $09-10-94$ & 24.69 & 6785.31 \\
\hline & & & & & 06-03-95 & 20.90 & 6789.10 \\
\hline & & & & & $07-28-95$ & 17.15 & 6792.85 \\
\hline & & & & & $09-23-96$ & 19.65 & 6790.35 \\
\hline & & & & & $09-26-97$ & 18.51 & 6791.49 \\
\hline \multirow[t]{7}{*}{ SP1 } & 48-115-28acb01 & Snake River Picnic & $6,820 *$ & 101 & $09-12-93$ & 9.04 & 6810.96 \\
\hline & & & & & 06-03-94 & 9.14 & 6810.86 \\
\hline & & & & & $09-10-94$ & 10.45 & 6809.55 \\
\hline & & & & & $06-06-95$ & 6.13 & 6813.87 \\
\hline & & & & & $07-27-95$ & 9.14 & 6810.86 \\
\hline & & & & & $09-23-96$ & 8.97 & 6811.03 \\
\hline & & & & & $09-26-97$ & 7.55 & 6812.45 \\
\hline
\end{tabular}

${ }^{1}$ Some measurements might be affected by pumping.

${ }^{2}$ Well FR7 is a shallow test well located about 400 feet north of water-supply wells FR1 and FR2. 


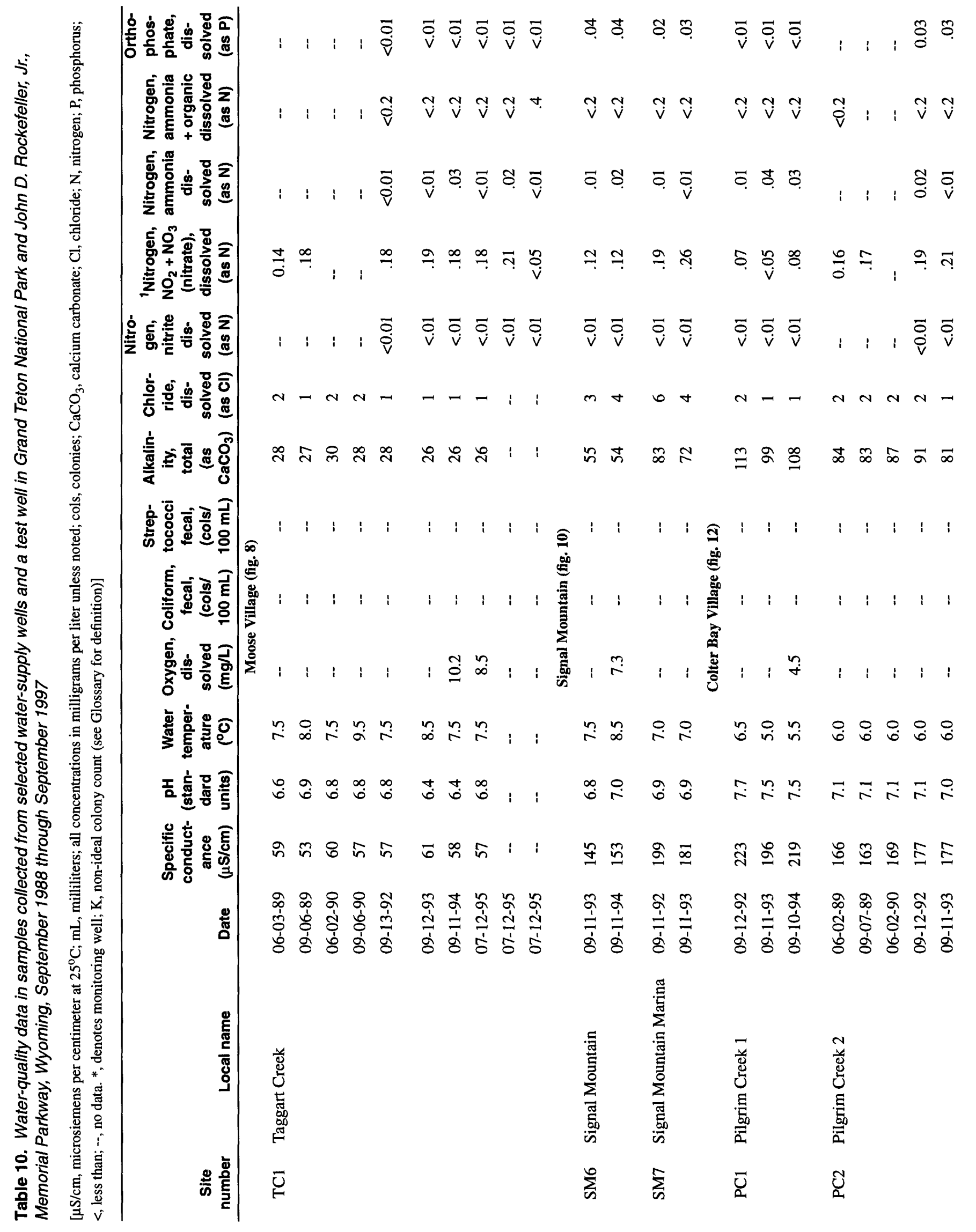




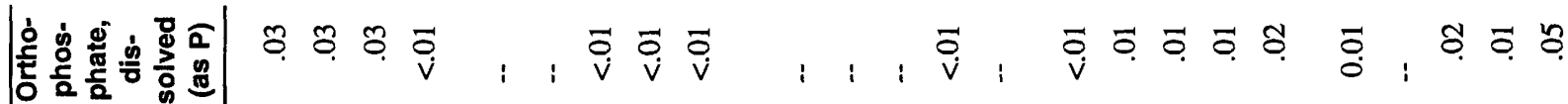

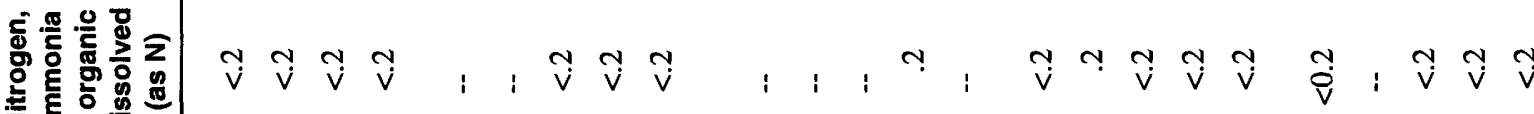

$\frac{5}{5}$

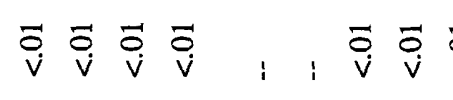

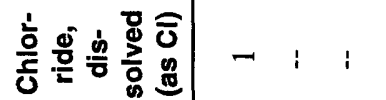

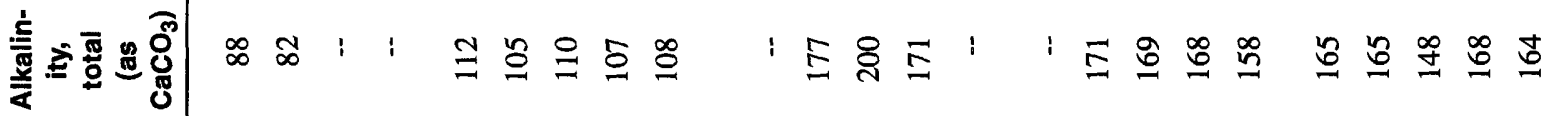

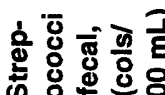

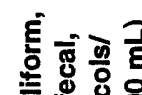

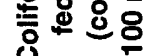

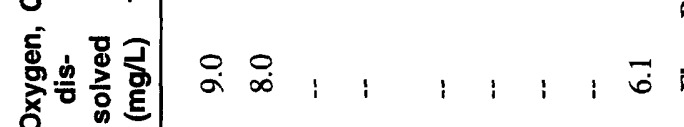

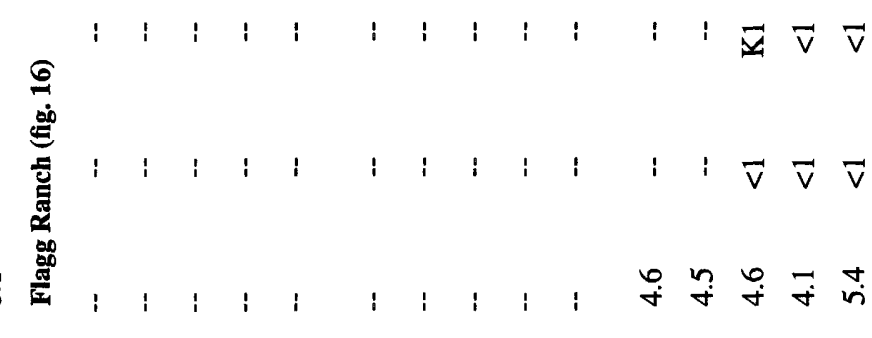

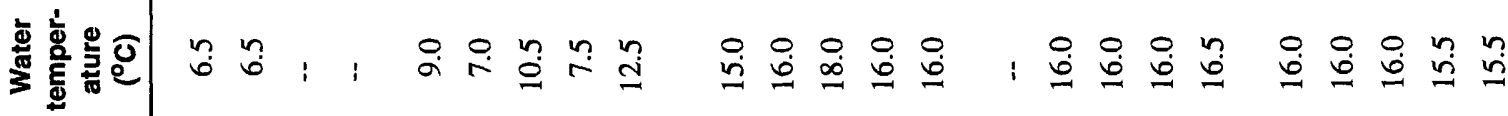

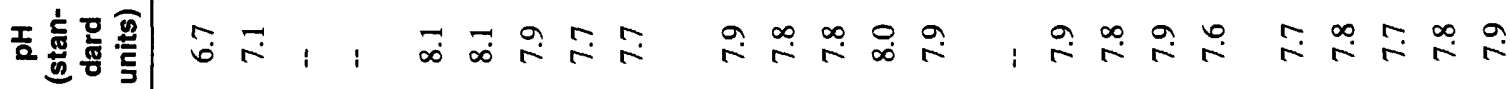




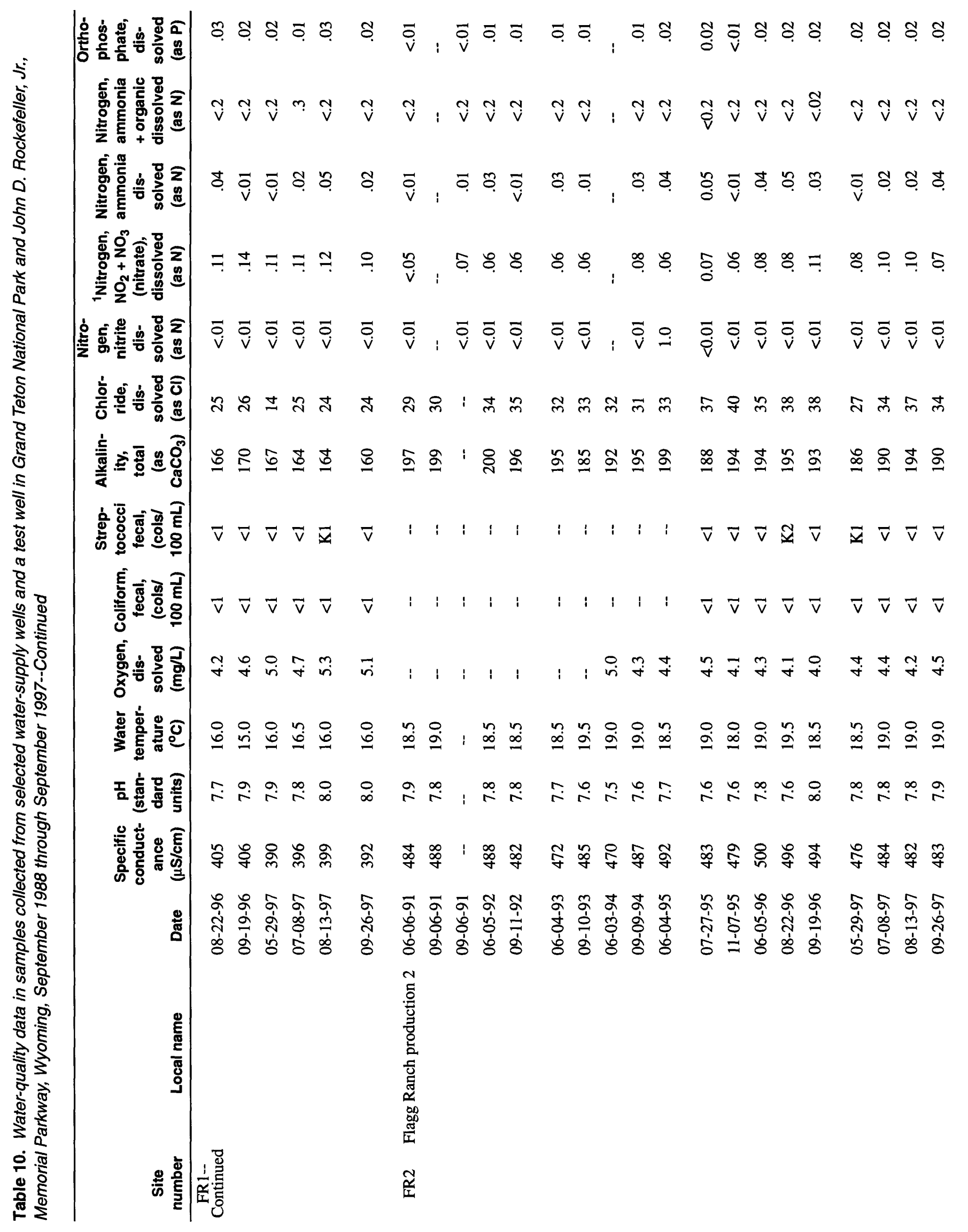


|

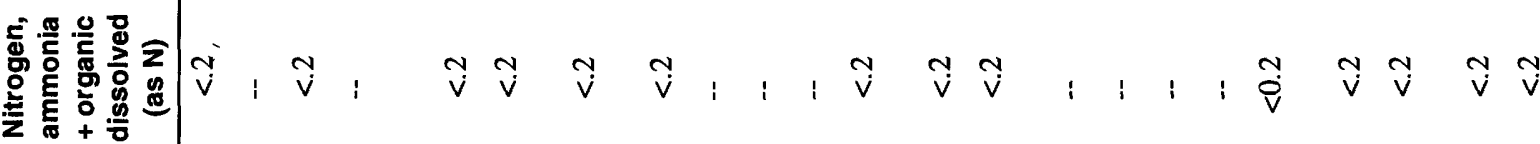

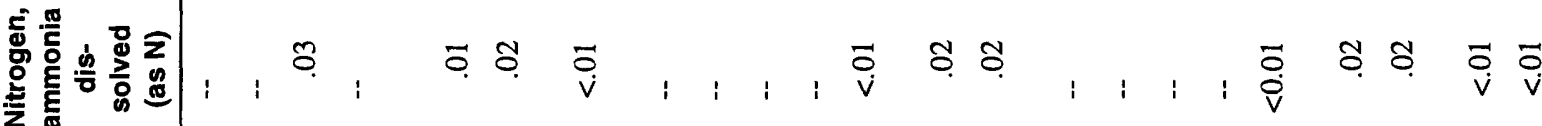

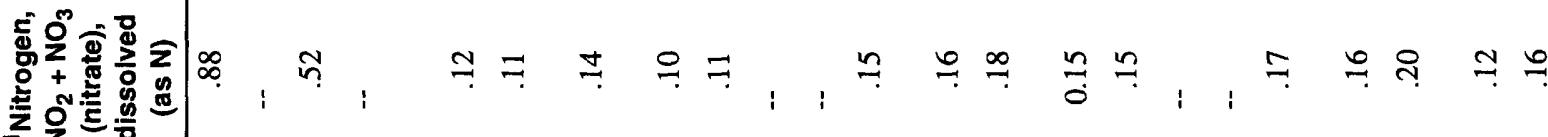

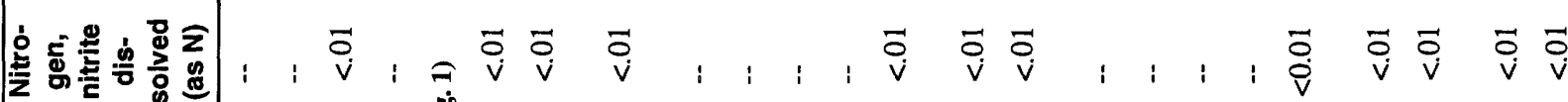

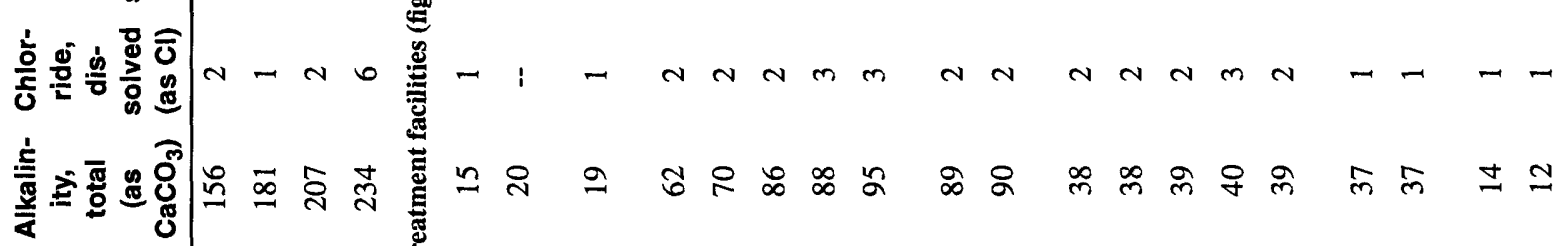
6 


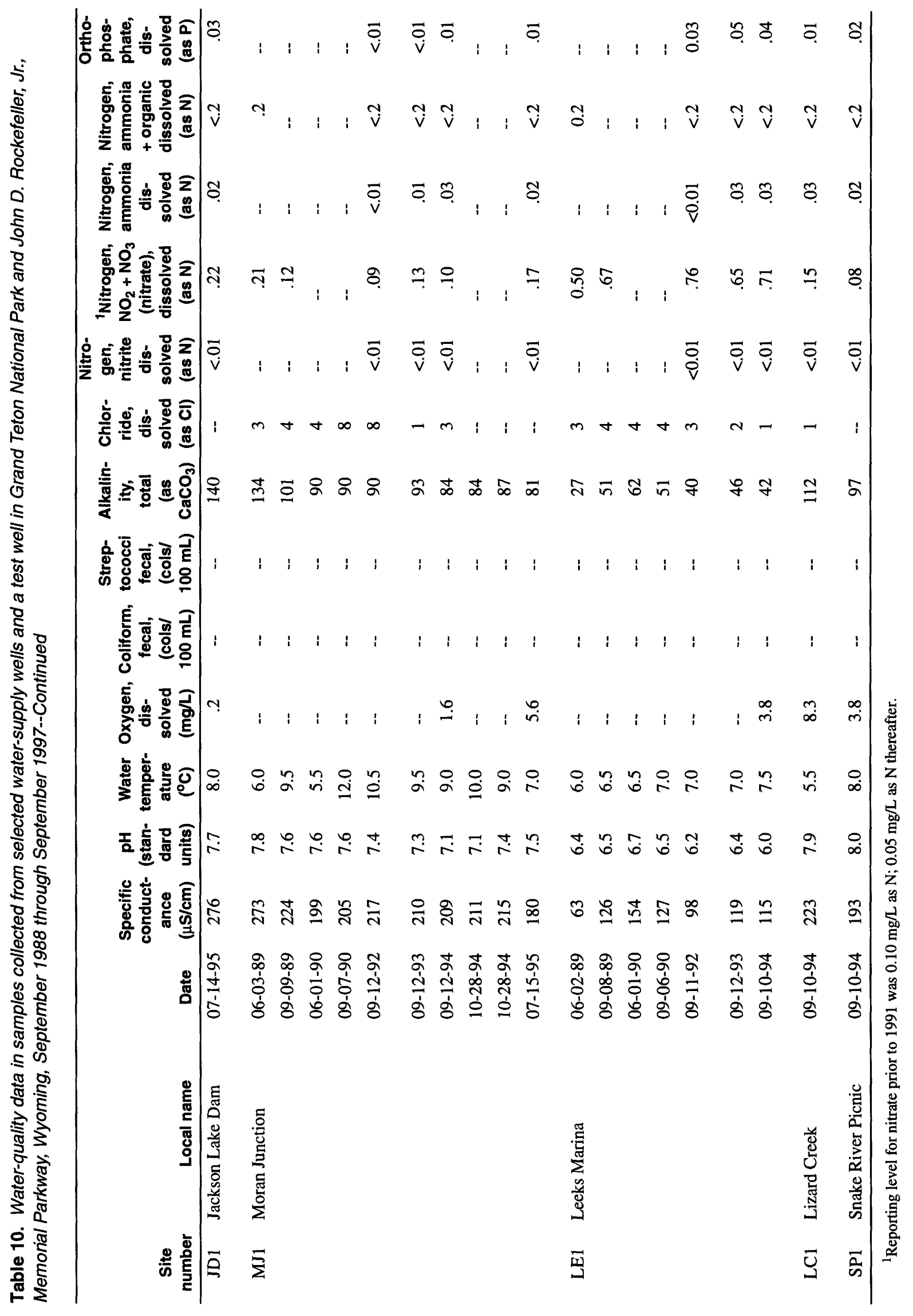




\section{SUMMARY}

Water-level measurements and chemical and biological data were collected and analyzed to assess the effects that four wastewater-treatment facilities located in Grand Teton National Park and John D. Rockefeller, Jr., Memorial Parkway, Wyoming, have on the ground-water quality near the facilities. Waterquality samples were collected from September 1988 through September 1997 from 21 monitoring wells and 8 water-supply wells located near the facilities, and 10 water-supply wells located in the study area, but not directly associated with the facilities.

In order to determine the direction of horizontal and vertical ground-water flow and to better monitor ground-water quality at the four wastewater-treatment facilities, additional monitoring wells installed around the four facilities would be useful.

Water-quality data in samples collected from monitoring wells near the Colter Bay Village wastewater-treatment facility located near Colter Bay Village indicate that reducing conditions exist in the ground water at the facility. The areal or vertical extent of the reducing zone is unknown. Geochemical evidence supporting this interpretation includes concentrations of dissolved oxygen, alkalinity, nitrate, and dissolved ammonia. A noticeable seasonal variation exists for specific conductance, alkalinity, dissolved chloride, and dissolved ammonia in samples collected from monitoring well CB5 in comparison to wells CB1, $\mathrm{CB} 2, \mathrm{CB} 3$, and $\mathrm{CB} 4$. A likely explanation for the seasonality of water quality in well CB5 is that treated wastewater from the facility is impacting the ground water being sampled from this well.

The contrasts of concentrations of dissolved oxygen, alkalinity, nitrate, and ammonia between wells CB5 and wells CB1, CB2, CB3, and CB4 are most likely the result of biologically mediated oxidationreduction processes occurring in the ground water. Reductive processes seem to be the best available explanation for the decreased concentrations of dissolved oxygen and nitrate, and the increased ammonia concentrations in samples collected from well CB5.

Water-level measurements and water-quality samples were typically collected in the spring (late May-early June), prior to heavy visitor use in the Park and Parkway, and during late summer and early fall (September-October), after heavy visitor use. Waterlevel measurements, in general, are highest in May and early June in comparison to water levels measured in
September, October, and November. The higher water levels are a result of recharge by rainfall, snowmelt, and snowmelt runoff in the spring. Water-quality analyses indicate that concentrations of selected constituents, in general, were lower in the spring than in the fall.

Samples collected at the Signal Mountain and Flagg Ranch wastewater-treatment facilities had high concentrations of selected constituents. Constituent concentrations appeared to decrease in samples collected after liners were replaced at these two sites, suggesting that the higher concentrations were the result of leaking liners. Concentrations of selected constituents were low in samples collected from wells near the Moose Village wastewater-treatment facility. Facility operations appear to have no apparent affect in water quality at the site.

Two samples analyzed for nitrate, of all the samples collected from 1988 through 1997, exceeded the Maximum Contaminant Level of $10 \mathrm{mg} / \mathrm{L}$ as N. Concentrations of nitrate, however, did exceed $3 \mathrm{mg} / \mathrm{L}$ as $\mathrm{N}$, which is generally thought to be a result of human activity.

Water-quality samples collected from the watersupply wells indicate that concentrations of selected constituents were low; thus, the supply wells are not being affected by the four wastewater-treatment facilities. Samples collected from supply wells at Flagg Ranch had higher measurements of specific conductance, water temperature, and higher concentrations of dissolved chloride than samples collected from other water-supply wells or monitoring wells. The higher values are probably the result of thermal activity in the area; Huckleberry Hot Springs is located about 3,000 ft west of the water-supply wells. Fecal streptococci bacteria concentrations were noted in four samples collected from the supply wells located at Flagg Ranch. Three samples from a shallow test well located about $400 \mathrm{ft}$ north of the supply wells also had bacteria concentrations. The source of the bacteria is unknown.

\section{SELECTED REFERENCES}

Bates, R.L., and Jackson, J.A., eds., 1980, Glossary of geology ( $2 \mathrm{~d}$ ed.): Falls Church, Va., American Geological Institute, $749 \mathrm{p}$. 
Behrendt, J.C., Tibbetts, B.L., Bonini, W.E., and Lavin, P.M., 1968, A geophysical study in Grand Teton National Park and vicinity, Teton County, Wyoming, with sections on Stratigraphy and structure, by J.D. Love, and Pre-Cambrian rocks, by J.C. Reed, Jr.: U.S. Geological Survey Professional Paper 516-E, 23 p.

Britton, L. J., and Greeson, P. E., 1988, Methods for collection and analysis of aquatic biological and microbiological samples: U.S. Geological Survey Techniques of Water-Resources Investigations, book 5, chapter A4, $685 \mathrm{p}$.

Cox, E. R., 1974, Water resources of Grand Teton National Park, Wyoming: U. S. Geological Survey Open-File Report, 114 p.

1977, Preliminary study of wastewater movement in and near Grand Teton National Park, Wyoming, through October 1976: U.S. Geological Survey OpenFile Report 77-275, $35 \mathrm{p}$.

Drever, J.I., 1997, The geochemistry of natural waters: surface and groundwater environments ( $3 \mathrm{~d}$ ed.): Upper Saddle River, New Jersey, Simon and Schuster/a Viacom Company, $436 \mathrm{p}$.

Fishman, M. J., and Friedman, L. C., eds., 1989, Methods for determination of inorganic substances in water and fluvial sediments ( $3 \mathrm{~d}$ ed.): U. S. Geological Survey Techniques of Water-Resources Investigations, book 5 , chapter $\mathrm{A} 1,545 \mathrm{p}$.

Friedman, L. C., and Erdman, D. E., 1982, Quality assurance practices for the chemical and biological analyses of water and fluvial sediments: U. S. Geological Survey Techniques of Water-Resources Investigations, book 5 , chapter A6, $181 \mathrm{p}$.

Hach Company, 1995, DR2000 Spectrophotometer Instruction Manual: Boulder, Colo., $692 \mathrm{p}$.

Hem, J.D., 1985, Study and interpretation of the chemical characteristics of natural water (3d ed.): U.S. Geological Survey Water-Supply Paper 2254, 263 p.

Love, J.D., and Christiansen, A.C., compilers, 1985, Geologic map of Wyoming: U.S. Geological Survey, scale $1: 500,000,3$ sheets.

Love, J.D., and Reed, J.C., Jr., 1968, Creation of the Teton landscape, the geologic story of Grand Teton National Park: Moose, Wyoming, Grand Teton Natural History Association, $120 \mathrm{p}$.

Love, J.D., Reed, J.C., Jr., and Christiansen, A.C., 1992, Geologic map of Grand Teton National Park, Teton County, Wyoming: U.S. Geological Survey Miscellaneous Investigations Series Map I-2031, scale $1: 62,500,1$ sheet.
Madison, R.J., and Brunett, J.O., 1985, Overview of the occurrence of nitrate in ground water of the United States, in National Water Summary 1984-Hydrologic events, selected water-quality trends, and ground-water resources: U.S. Geological Survey Water-Supply Paper 2275, p. 93-105.

Martner, B.E., 1986, Wyoming climate atlas: Lincoln, University of Nebraska Press, 432 p.

Mott, D.N., 1998, Grand Teton National Park, Wyoming, water resources scoping report: Moose, Wyoming, National Park Service, Grand Teton National Park, $57 \mathrm{p}$.

National Oceanographic and Atmospheric Administration, 1989-97, Climatological Data, Wyoming: Asheville, N.C., National Climatic Data Center, vol. 98-106 (issued monthly), various pagination.

National Park Service, 1986, Natural resources management plan and environmental assessment for Grand Teton National Park: Moose, Wyoming, National Park Service, Grand Teton National Park, 459 p.

Nolan, B. T., and Miller, K. A., 1995, Water resources of Teton County, Wyoming, exclusive of Yellowstone National Park: U.S. Geological Survey WaterResources Investigations Report 95-4204, 76 p.

Parliman, D. J., and Young, H. W., 1989, Ground-water data from selected sites, Grand Teton National Park, Wyoming: U. S. Geological Survey Open-File Report 89-51, 1 sheet.

Tibbetts, B.L., Behrendt, J.C., and Love, J.D., 1969, Seismic refraction measurements in Jackson Hole, Wyoming: Geologic Society of America Bulletin 80, p. 1109-1122.

Todd, D.K., 1980, Groundwater Hydrology (2d ed.): New York, John Wiley and Sons, Inc., 535 p.

U. S. Environmental Protection Agency, 1993, Guidelines for delineation of wellhead protection areas: EPA 440/ 5-93-001, $188 \mathrm{p}$.

1996, U. S. Code of Federal Regulations, Title 40, Parts 136 to 149, revised as of July 1, 1996: 757 p.

Young, H. W., Parliman, D. J., Jones, M. L., and Stone, M. A. J., 1991, Hydrologic and water-quality data for selected sites, Grand Teton National Park, Wyoming, September 1988 through September 1990: U. S. Geological Survey Open-File Report 91-56, 23 p. 


\section{GLOSSARY}

Alluvium consists of clay, silt, sand, gravel, and boulders, or other unconsolidated material deposited by a stream or other body of running water as a sediment in the bed of a stream or on a floodplain or delta, or as a fan at the base of a mountain.

Aquifer is a body of rock that contains sufficient saturated, permeable material to yield substantial quantities of water to wells and springs.

Bacteria are microscopic unicellular organisms, typically spherical, rodlike, or spiral and threadlike in shape, often formed into colonies. Some bacteria cause disease, while others perform an essential role in nature in the recycling of materials; for example, by decomposing organic matter into a form available for reuse by plants.

Benchmarks are permanent markers embedded in a fixed and enduring natural or artificial object, indicating a precisely determined elevation above or below a standard datum (usually sea level) and bearing identifying information, and used as a reference in topographic surveys.

Dissolved refers to a substance present in true chemical solution. In practice, however, the term includes all forms of substances that will pass through a 0.45 -micrometer membrane filter, and thus may include some very small (colloidal) suspended particles.

Fecal coliform bacteria are bacteria that are present in the intestine and feces of warm-blooded animals. They are often used as indicators of the sanitary quality of water. Their concentrations are expressed as numbers of colonies per $100 \mathrm{~mL}$ of sample.

Fecal streptococcal bacteria also are bacteria found in the intestine of warm-blooded animals. Their presence in water is considered to verify fecal pollution. Their concentrations are listed as number of colonies per $100 \mathrm{~mL}$ of sample.

Limestone is dense rock formed by chemical precipitation of calcium carbonate from solution in water.

Median is the middle number in a given sequence, or the average of the two middle numbers when the sequence has an even number of numbers. Median is not the average of the numbers.

Milligrams per liter is a unit expressing the concentration of chemical constituents in solution as mass (milligrams) of solute per unit volume (liter) of water.
Moraine is a mound, ridge, or other distinct accumulation of unsorted, unstratified material deposited chiefly by direct action of a glacier, in a variety of topographic landforms that are independent of control by the surface on which the material lies.

Non-ideal colony count $(K)$ is a remark code used in reporting bacteria densities when plate counts fall outside of the ideal range. The lower limit of 20 colonies is set as the number below which statistically valid results become increasingly questionable. The upper limit, which differs according to type of bacteria, represents numbers above which interference from colony crowding, deposition of extraneous material, and other factors appear to result in increasingly questionable results.

Percentile is one of the values of a variable that divides the distribution of the variable into 100 groups having equal frequencies. In this report, the 25 th and 75 th percentile are used. Median also is used and is equivalent to the 50th percentile.

pH is a measure of the acidity or alkalinity of water. It is defined as the negative logarithm of the hydrogen-ion concentration. This property is dimensionless and has a range of 0 to 14 , with a $\mathrm{pH}$ of 7 representing neutral water. A pH greater than 7 indicates the water is alkaline, whereas a pH less than 7 indicates an acidic water.

Specific conductance is a measure of the ability of the water to conduct an electrical current. It is expressed in microsiemens per centimeter at 25 degrees Celsius. Specific conductance is related to the type and concentrations of ions in solution and can be used for approximating the dissolved-solids concentration of the water.

Unconsolidated refers to sediment grains that are loose, separate, or unattached to one another.

Unsaturated zone is the zone between the land surface and the water table. It includes the capillary fringe. Generally, water in this zone is under less than atmospheric pressure, and some of the voids may contain air and other gases at atmospheric pressure.

Water table refers to the upper surface of the saturated zone where the water pressure is equal to atmospheric pressure. 


\section{APPENDIX I}

Available well-construction records of selected water-supply wells and monitoring wells located near four wastewater-treatment facilities in Grand Teton National Park and John D. Rockefeller, Jr., Memorial Parkway, Wyoming 


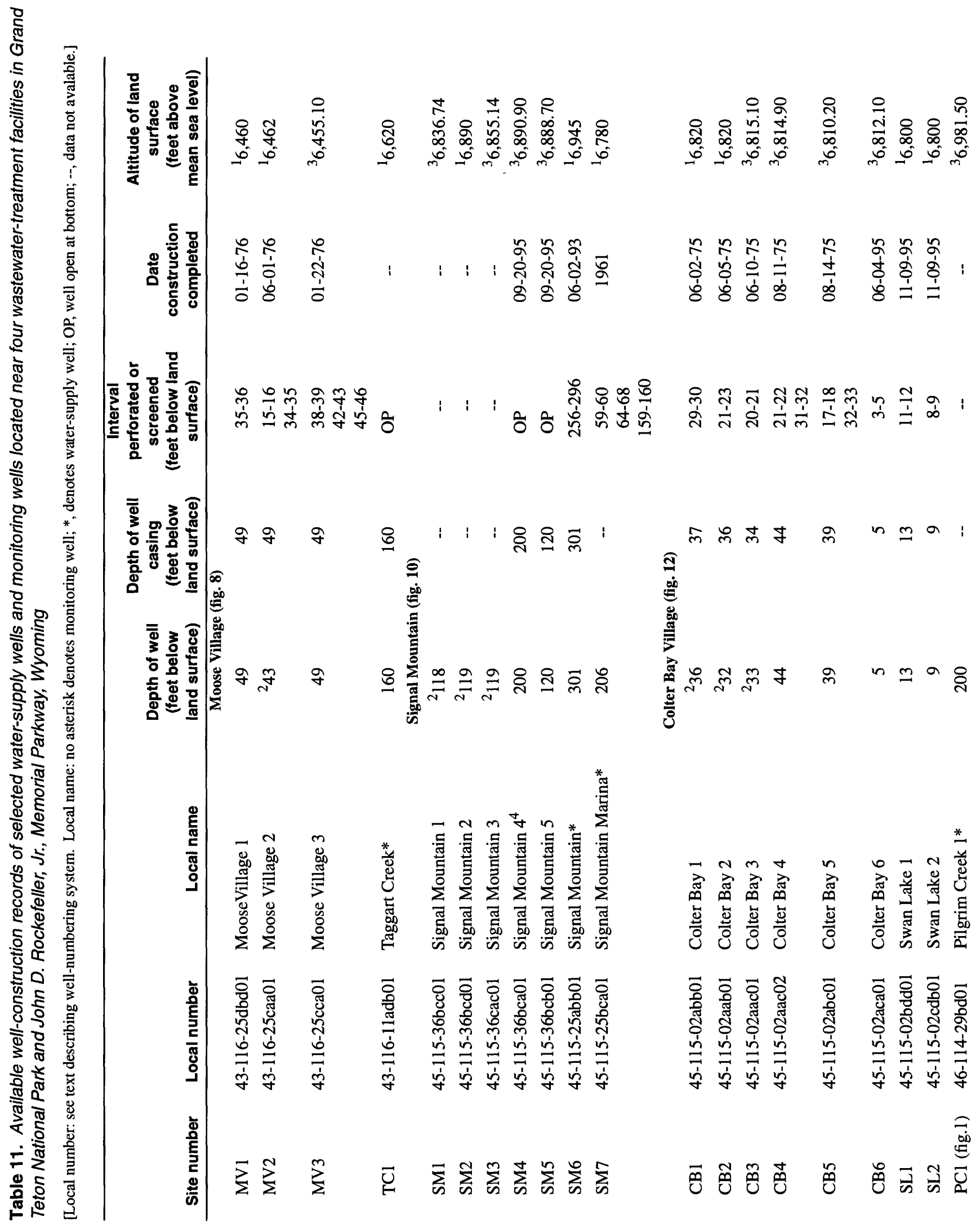




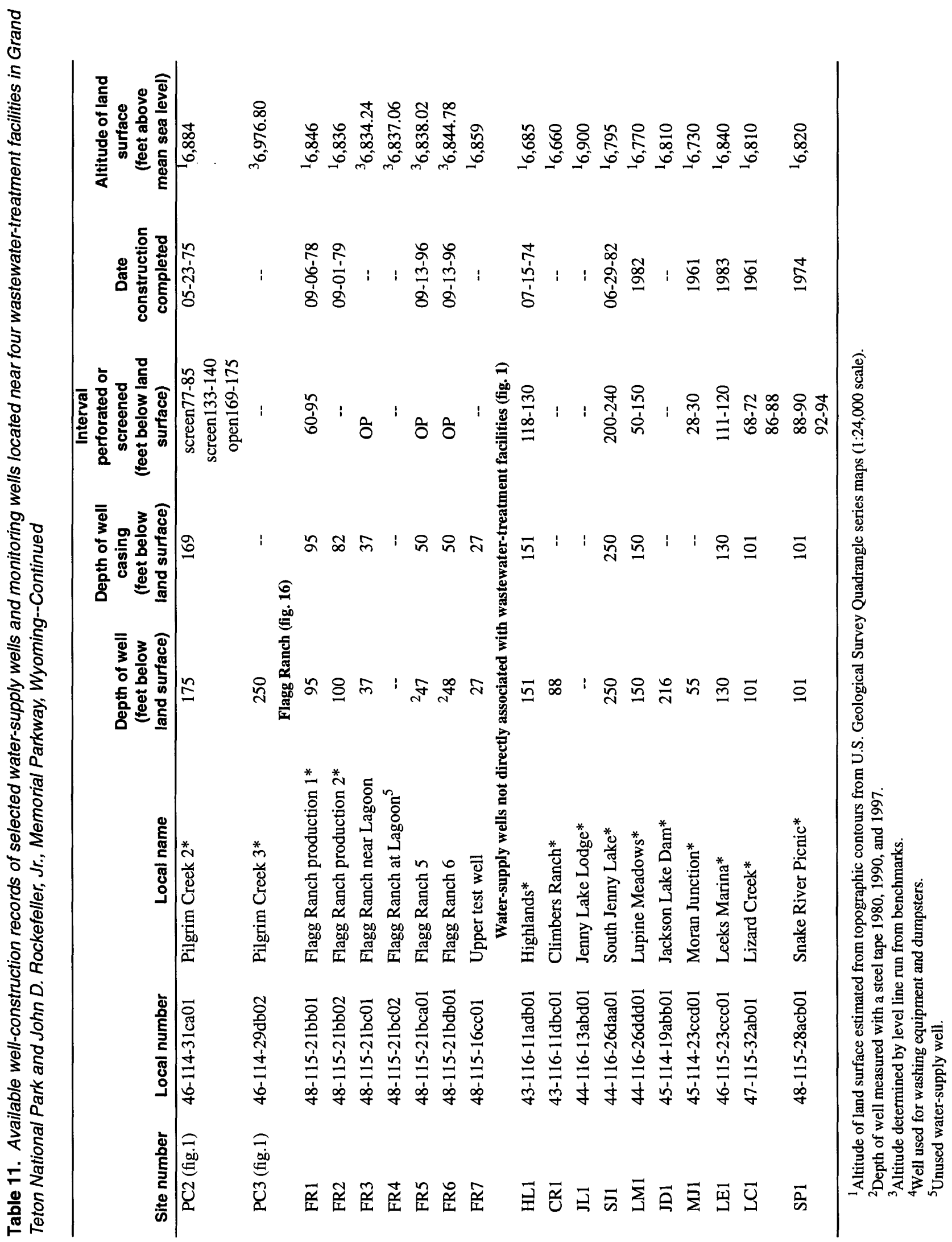




\section{APPENDIX II}

Well logs of selected monitoring wells located near four wastewater-treatment facilities in Grand Teton National

Park and John D. Rockefeller, Jr., Memorial Parkway, Wyoming 

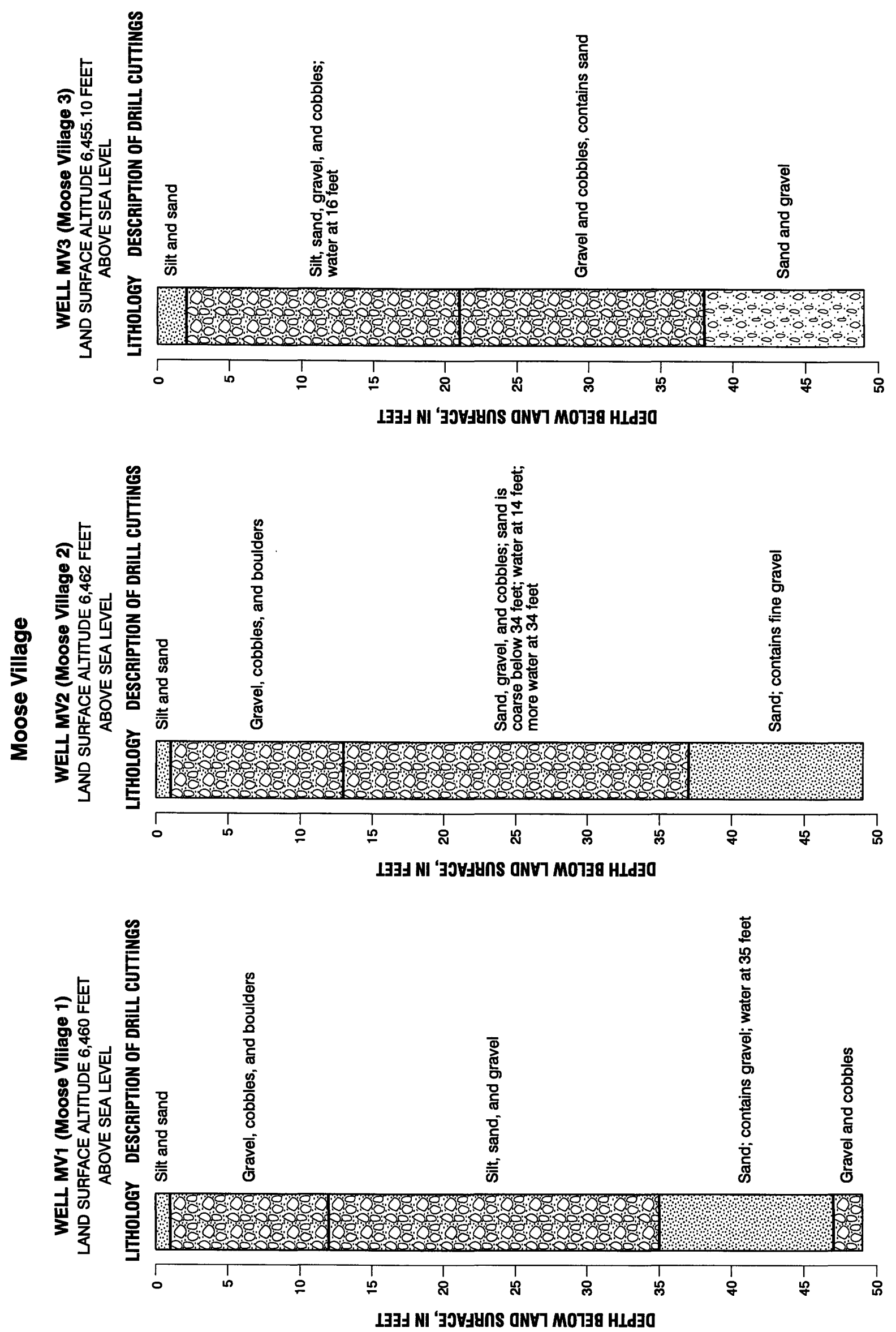


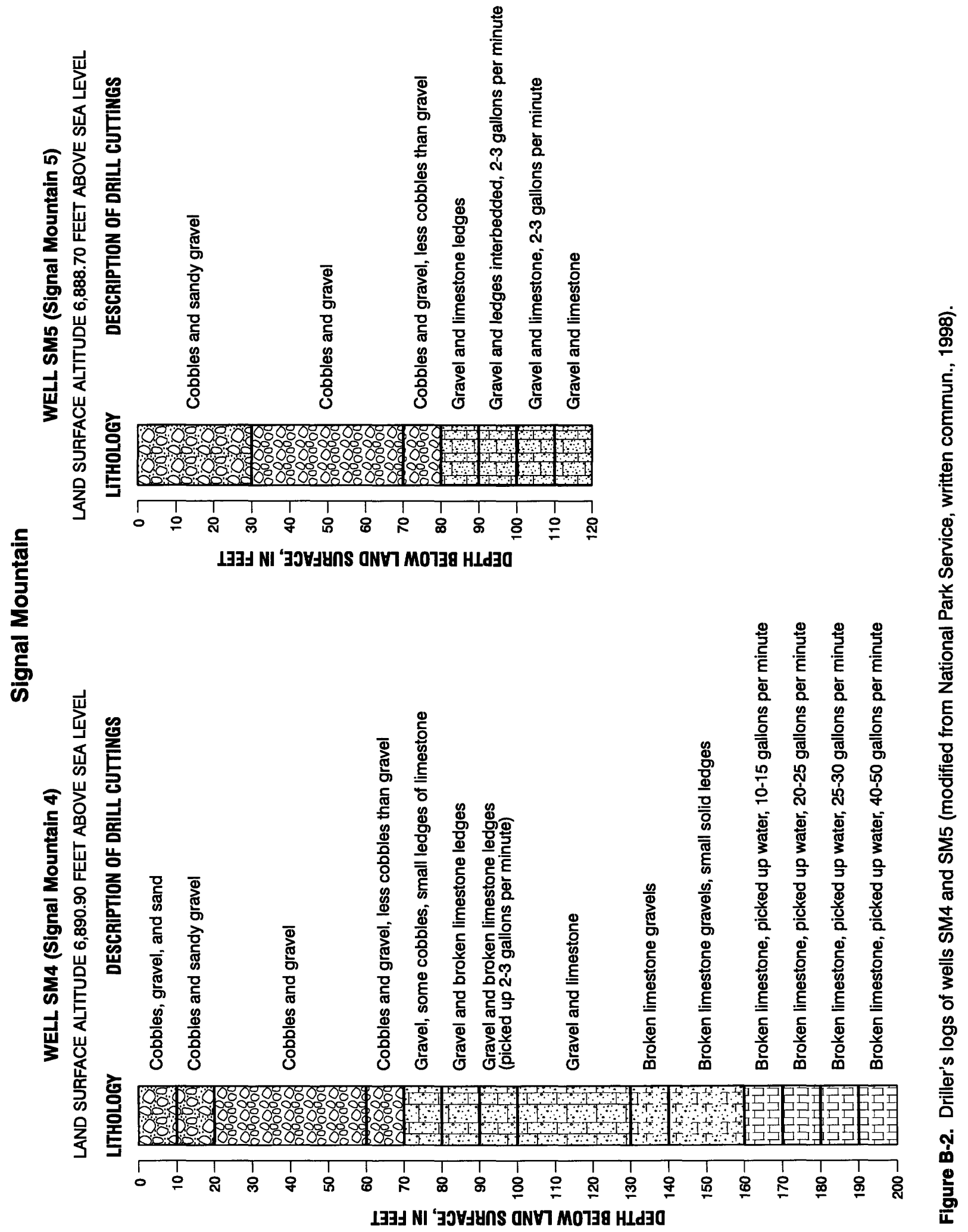



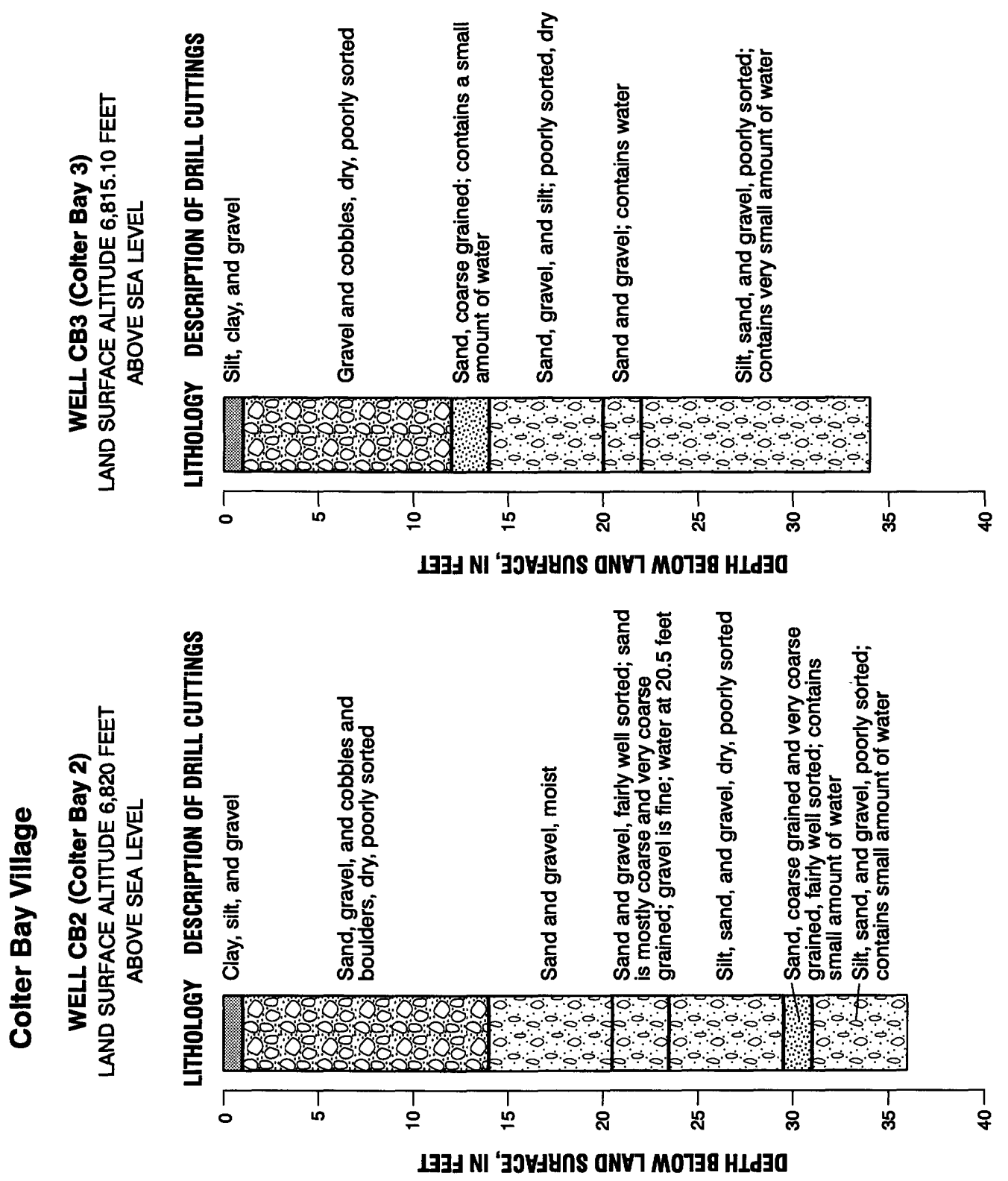

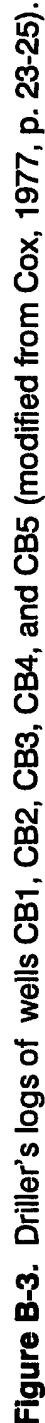




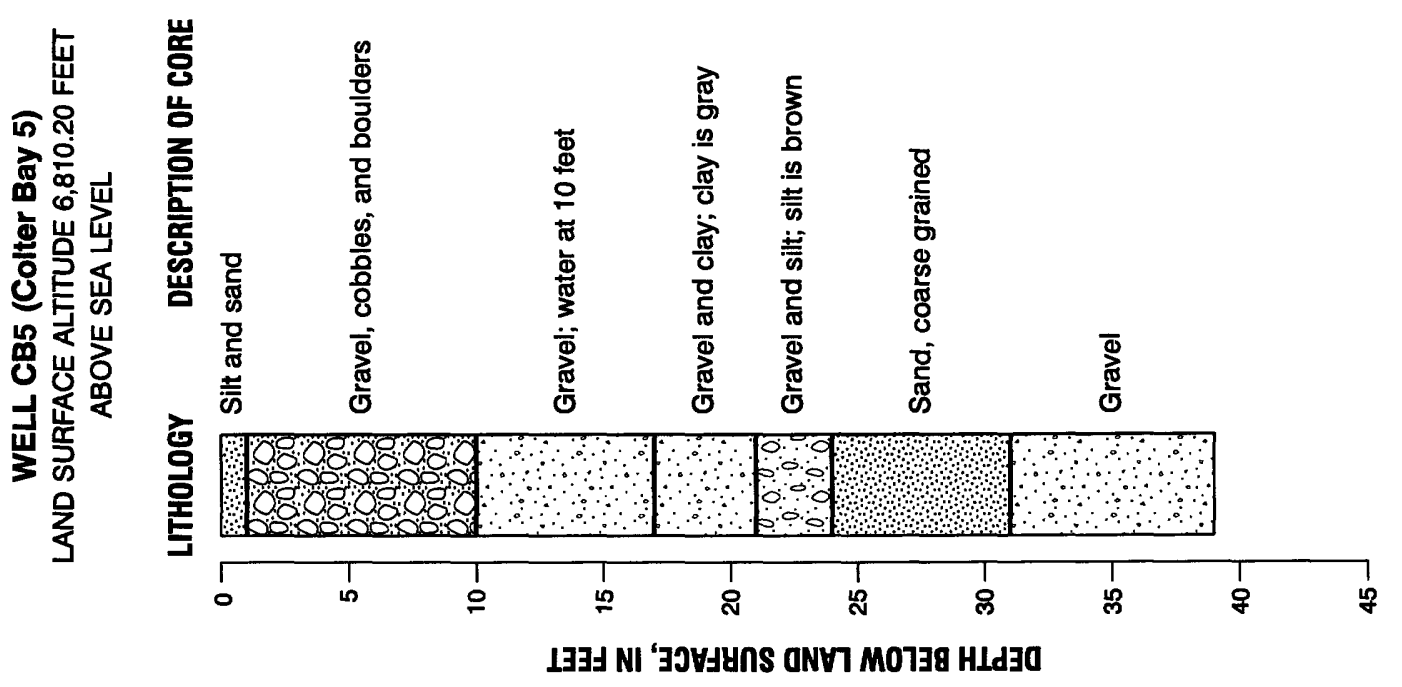

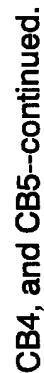

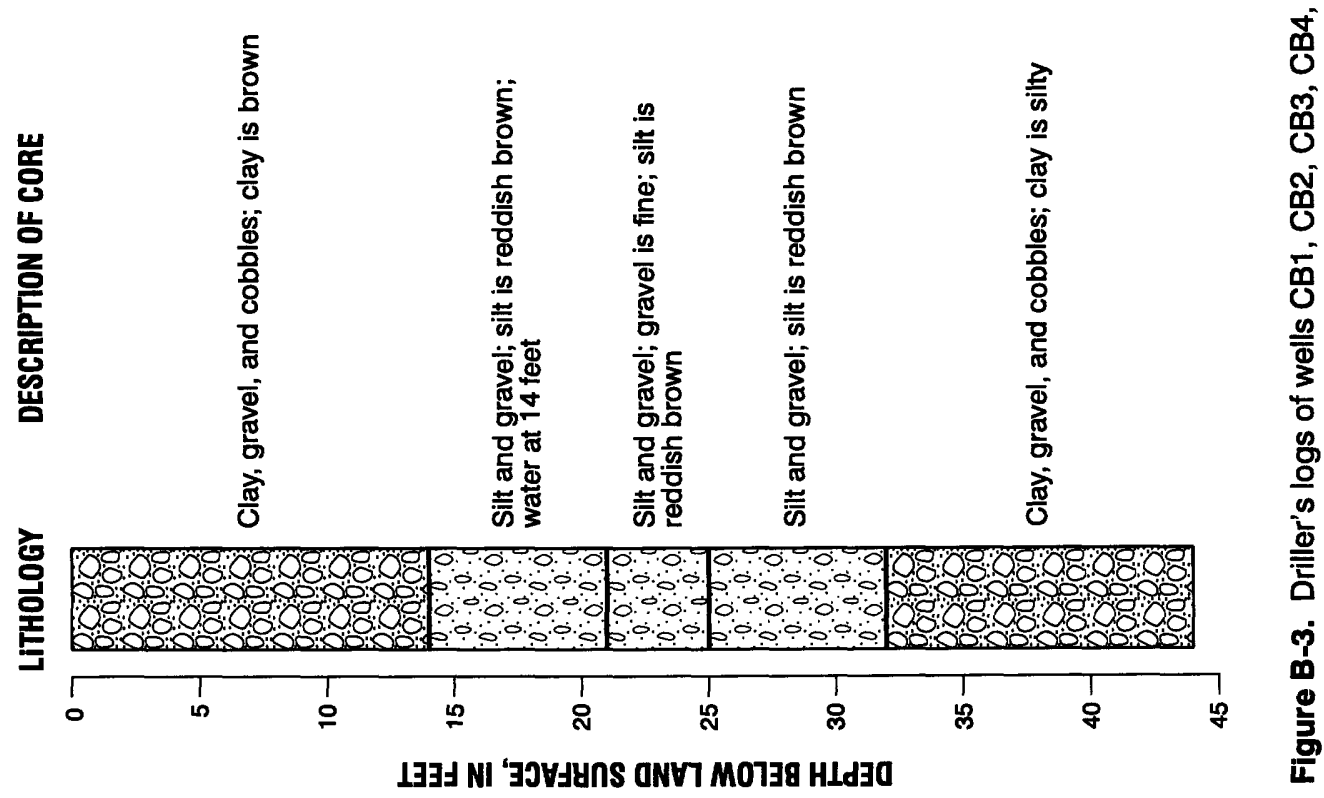




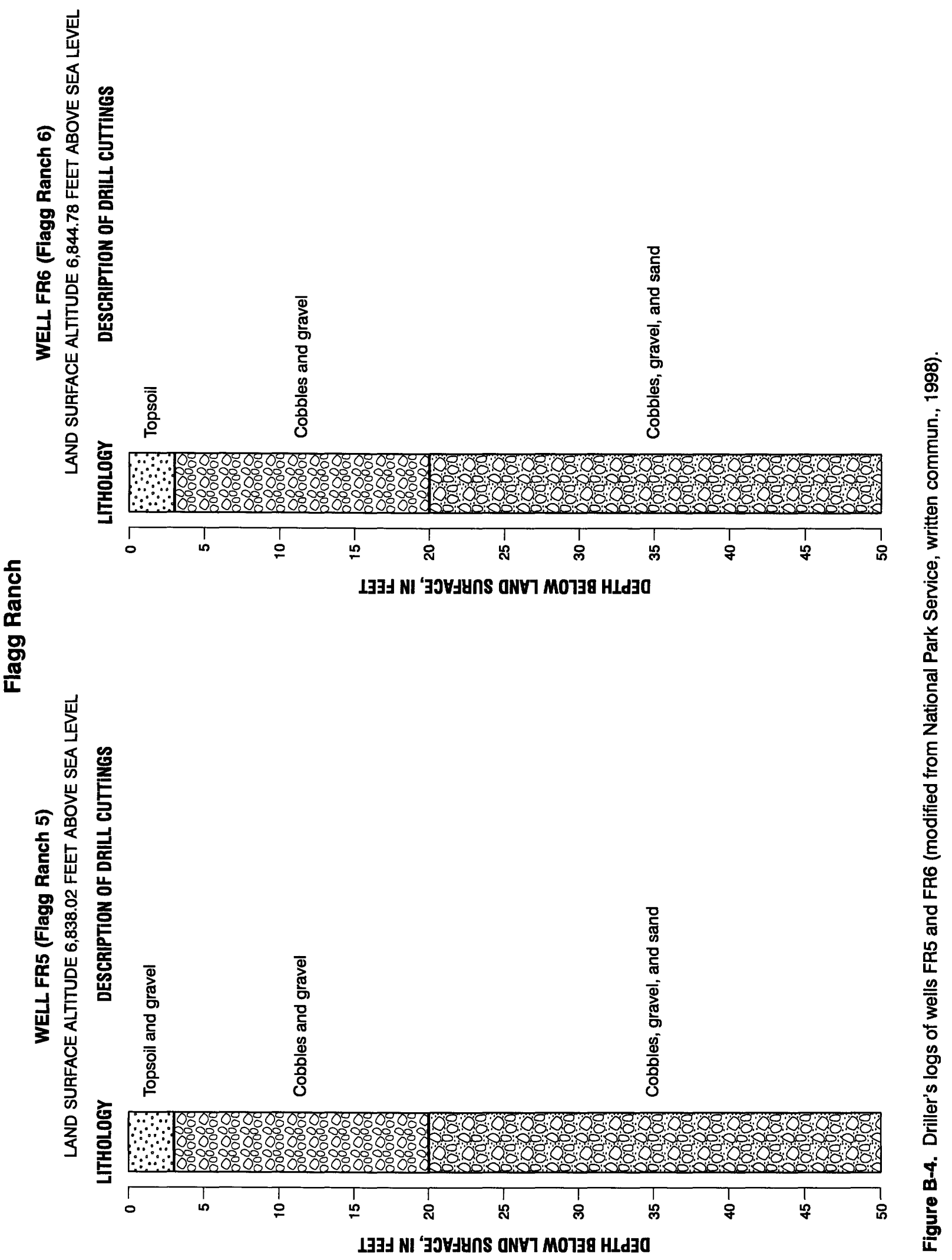

